University of Nebraska - Lincoln

DigitalCommons@University of Nebraska - Lincoln

Agronomy \& Horticulture - Faculty Publications

Agronomy and Horticulture Department

1996

\title{
Germplasm and Cultivar Development
}

M. D. Casler

University of Wisconsin, michael.casler@ars.usda.gov

Jeffrey F. Pedersen

University of Nebraska-Lincoln, jpedersen1@unl.edu

G. C. Eizenga

USDA-ARS

S. D. Stratton

FFR Cooperative

Follow this and additional works at: https://digitalcommons.unl.edu/agronomyfacpub

Part of the Agricultural Science Commons, Agriculture Commons, Agronomy and Crop Sciences Commons, Botany Commons, Horticulture Commons, Other Plant Sciences Commons, and the Plant Biology Commons

Casler, M. D.; Pedersen, Jeffrey F.; Eizenga, G. C.; and Stratton, S. D., "Germplasm and Cultivar Development" (1996). Agronomy \& Horticulture -- Faculty Publications. 954.

https://digitalcommons.unl.edu/agronomyfacpub/954

This Article is brought to you for free and open access by the Agronomy and Horticulture Department at DigitalCommons@University of Nebraska - Lincoln. It has been accepted for inclusion in Agronomy \& Horticulture -Faculty Publications by an authorized administrator of DigitalCommons@University of Nebraska - Lincoln. 


\title{
14 Germplasm and Cultivar Development ${ }^{1}$
}

\author{
M. D. CASLER \\ University of Wisconsin \\ Madison, Wisconsin \\ J. F. PEDERSEN \\ USDA-ARS \\ Lincoln, Nebraska \\ G. C. EIZENGA \\ USDA-ARS \\ Stuttgart, Arkansas \\ S. D. STRATTON \\ FFR Cooperative \\ West Lafayette, Indiana
}

Cool-season forage grasses have evolved, and continue to evolve, in natural ecosystems subject to environmental factors both in the presence and absence of human influences. The literature often lacks facts describing the evolution and domestication of forage grasses. Furthermore, the literature on this subject mainly deals with evolution of species in the broad scope, i.e., on a scale of hundreds of thousands or millions or years. Thus, some of our conclusions are necessarily speculative and are highly subject to the nature of the research that has been reported. We describe the forces of selection that act upon cool-season forage grasses and attempt to place each in historical perspective and in relation to each other. Because most economically important cool-season forage grasses are perennial, our principal focus will be on perennial species.

There has been very little effort to quantify economic values of selection criteria or to empirically compare different breeding procedures in cool-season forage grasses. We attempt to summarize and compare some of the more important and thoroughly reported approaches used since the advent of formal breeding strategies in the late nineteenth and early twentieth centuries. These selection criteria and breeding procedures are as varied as the individual researchers who developed them. Examples are cited to illustrate principles and phenomena of historical or practical importance. More details of the agriculturally important species are discussed in the later chapters of this book. Space limitations prevent

\footnotetext{
${ }^{1}$ Common names for plants have been used throughout the chapter. Refer to the appendix for the scientific name.
}

Copyright (C) 1996 American Society of Agronomy, Crop Science Society of America, Soil Science Society of America, 677 S. Segoe Rd., Madison, WI 53711, USA. Cool-Season Forage Grasses, Agronomy Monograph no. 34. 
us from developing a thorough review, but we cite earlier reviews that thoroughly cover the first few decades of formal cool-season forage grass breeding.

We also have summarized the limited amount of research on cool-season forage grasses where attempts have been made to use new technologies for hybridization, tissue culture, and genetic markers. Many of these techniques were first developed using other species and later adapted to cool-season forage grasses. Many are still undergoing rapid development and modification to allow more efficient use in breeding programs. Together they have had little practical impact on cool-season forage grass cultivars, but appear to offer considerable promise for creating new genetic variability and more efficient breeding procedures.

\section{HISTORICAL DEVELOPMENT OF COOL-SEASON GRASS BREEDING}

Darwin $(1868,1875)$ described three types of selective forces that may act to modify populations of organisms. Natural selection is the process whereby those individuals best fitted to a particular environment, a range of fluctuating environments, or a human-imposed management system have the greatest survival rate or contribute the greatest numbers of viable progeny to succeeding generations. Second, unconscious selection is the process by which humans save the phenotypically most valuable or desirable individuals, or their seed, and destroy or ignore the less valuable or desirable individuals. This process allows humans to facilitate genetic changes insofar as genetic variation allows, without the need to define or predetermine the selection criteria or potential correlated traits. Finally, methodical selection comprises the forces that are applied by humans in their systematic attempts to create predetermined changes to populations. All three of these types of forces have acted and continue to act in various ways, sometimes in concert, sometimes in disharmony, to create the world's pool of cool-season forage grass germplasms.

\section{Natural Selection}

The forces of natural selection which may affect the genetic and phenotypic composition of forage grass populations can be categorized into two groups: genetic interactions with the physical environment (abiotic) and genetic interactions with other biological organisms (biotic). In reality, these two factors affecting the genetic response to natural selection are often inseparable. Genetic shifts associated with grazing, for example, may be strongly influenced by levels of soil moisture and/or soil fertility, or by soil type. Nevertheless, review of the literature suggests that natural selective forces acting upon cool-season forage grasses can be categorized into one of the above groups. In this review, we attempt to summarize the forces that seem to have been most important in the evolution of cool-season forage grasses since the beginnings of agriculture, and to show prominent examples of physical environment characteristics and biological organisms that affect the genetic composition of these grasses. 
Natural selection over the course of 50 or more years under an infrequent cutting management led to dramatic population differentiation in sweet vernalgrass (Snaydon, 1970). Evolution in these meadows was strongly mediated by artificially created differences in the physical environment, mainly soil $\mathrm{pH}$ and fertility. Soil $\mathrm{pH}$ strongly influenced $(r=0.95)$ the ability of evolved populations to respond to liming, populations derived form limed plots grew more rapidly on calcareous soils ( $\mathrm{pH}$ 8.2) and populations derived from unlimed plots grew more rapidly on acid soils ( $\mathrm{pH}$ 4.3-4.6). Surviving plants from unlimed plots also were more tolerant of high Al concentration (Fig. 14-1) and more responsive to increasing levels of Ca in sand culture (Davies \& Snaydon, 1973a) than were plants from unlimed plots. Similarly, surviving plants form high-P soils were more responsive to increasing levels of $\mathrm{P}$ in sand culture than were plants from low-P soils (Davies \& Snaydon, 1974). These changes appear to represent adaptive genetic shifts to divergent physical environments (Snaydon \& Davies, 1972; Snaydon, 1978). Orchardgrass, perennial ryegrass, and colonial bentgrass are amenable to similar evolutionary forces (Jowett, 1959; Crossley \& Bradshaw, 1968). Adaptive genetic shifts also may occur in relatively few years during seed multiplication of cultivars on soils with extreme pH levels (Crossley \& Bradshaw, 1968).

Numerous types of biological organisms provide natural selective forces that act upon cool-season forage grasses. Perhaps the most dramatic, most studied, and most historically important illustration is the effect of grazing on the genetic composition of pastures. Several authors have reviewed literature and described the effects of grazers and grazing management on grassland productivity and species composition (Watkin \& Clements, 1978; McNaughton et al., 1982; Coleman et al., 1989). Forage grasses have most certainly coevolved with grazers (Stebbins, 1981) and have necessarily evolved traits that allow them to survive under grazing pressure. Mixtures of perennial ryegrass and Italian ryegrass invariably show rapid $(<2 \mathrm{yr})$ genetic shifts toward the perennial ryegrass phenotype when subjected to grazing pressure, natural selective effects that grow stronger with increased intensity of grazing (Brougham et al., 1960; Charles, 1964; Brougham \& Harris, 1967). Selection for survival in perennial ryegrass during 6 yr of grazing led to a $7 \%$ increase in forage yield for 'S23' survivors and a $10 \%$ increase in 'S24' survivors compared to their respective original populations (Charles, 1972). Perennial ryegrass plants adapted to grazing pressure are generally prostrate in growth habit, late in maturity, and have a high capacity for tillering (Breese, 1983). Perennial ryegrass appears to be specifically adapted to survive in association with grazers (Beddows, 1953; Breese, 1983) and is rarely found in natural ecosystems without grazing pressure (Davies et al., 1973). Breese (1983) suggested that the evolution and migration of perennial ryegrass may be linked with the evolution and development of ruminant livestock farming. Both perennial ryegrass and ruminant livestock farming likely have their origins in the Mediterranean basin (Terrell, 1968; Harlan, 1975).

Populations of other cool-season forage grass species appear to be considerably less responsive than those of the ryegrasses to the selective effects of grazers. In a 50:50 mixture of early and late-flowering orchardgrass cultivars, there were no differences in the frequency of early flowering plants after 11 mo of 


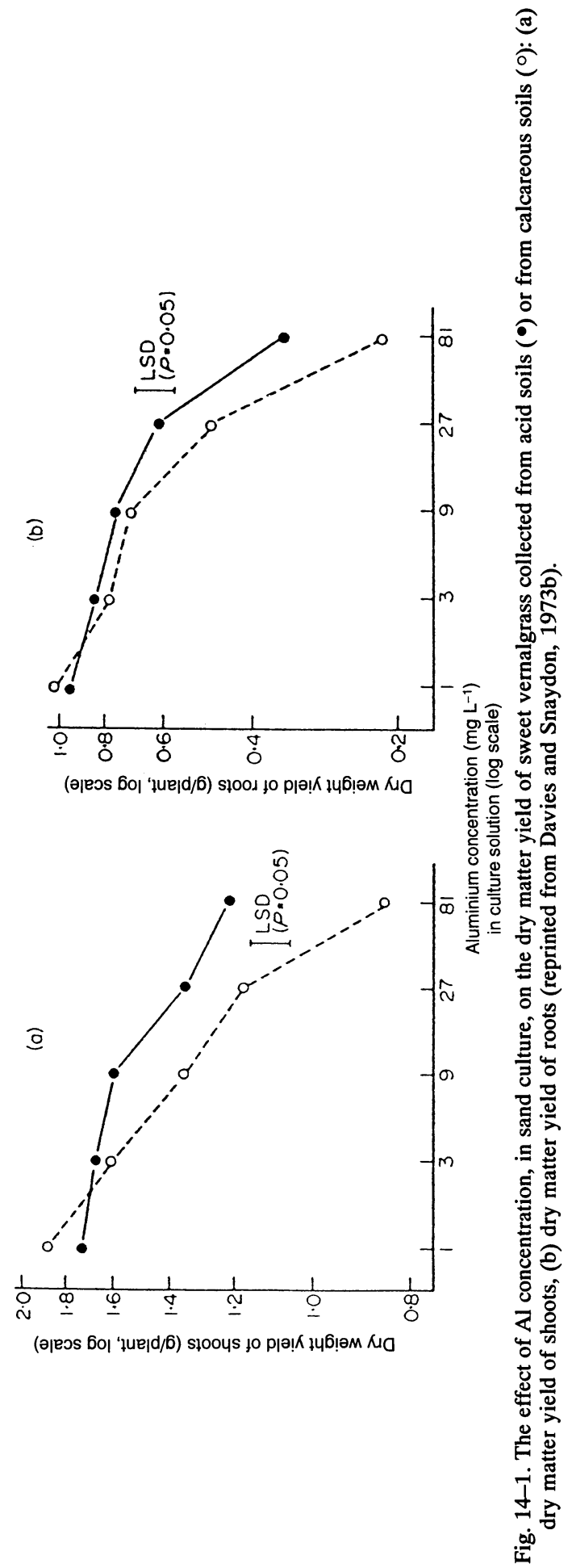


frequent grazing, infrequent grazing, or infrequent clipping (Charles, 1961). Orchardgrass plants that survived 4 yr of grazing differed only slightly, for 15 traits, from unselected plants (Tsurumi et al., 1985). However, natural selection induced genotype $\times$ environment $(G \times E)$ interactions; the five cultivars had different responses to grazing pressure and their phenotypic changes were a function of the site upon which they were grazed (Tsurumi et al., 1985). Van Dijk (1955) selected random timothy plants from Dutch pastures with a range of grazing managements. Plants surviving from 1 to $20 \mathrm{yr}$ of grazing were nearly identical in the distribution of maturity and growth habit classes to commercial haytype strains of timothy (Van Dijk, 1955). Plants surviving $\geq 21$ yr of grazing had approximately twice as high a frequency of prostrate or semi-prostrate plants and 19 times the frequency of medium- to late-flowering plants as as those from pastures $<21 \mathrm{yr}$ old. There were similar, but considerably smaller, trends for orchardgrass (Van Dijk, 1955). Furthermore, there were no differences in morphology of timothy and orchardgrass plants collected from dedicated pastures, hay fields, or combination hay/pasture fields, suggesting that evolution of lateflowering, prostrate types of timothy and orchardgrass in the oldest fields was not a response to grazing pressure per se, but a long-term adaptation to regular defoliation, either by the animal or machine.

Because of their high capacity for vegetative reproduction, grazing- or clipping-tolerant genotypes of perennial grasses have the potential to live indefinitely, despite the stresses of frequent defoliation. The largest plants in a population of crested wheatgrass had the lowest percentages of defoliation by grazing animals (Norton \& Johnson, 1981), suggesting their potential to dominate the sward. A natural population of German velvetgrass appeared to consist of only four genotypes, one of which had ramets covering a distance of $800 \mathrm{~m}$ (Harberd, 1961), while a genotype of sheep fescue was estimated to be at least $1000 \mathrm{yr}$ old (Harberd, 1962). Owen and Wiegert (1981) suggested that large, long-lived, rametforming grasses have evolved in response to grazing and cannot survive without grazing pressure. Indeed, some grasses that have evolved in long-term grasslands cannot survive when grazing pressure is removed (McNaughton, 1979). Furthermore, there is evidence that ruminant saliva may stimulate the growth of grasses adapted to natural pasture or rangeland ecosystems (see reviews by Fily et al., 1991; Matches, 1992).

All cool-season forage grasses contain lignin, silica, and phenolic compounds in quantities sufficient to limit intake by ruminant animals (Van Soest, 1982). These compounds may act as a general defense mechanism for grasses to maintain fitness under the stresses of grazing pressure (McNaughton, 1979; Owen $\&$ Wiegert, 1981). Many of these compounds also are genetically related to the nutritive value of grass herbage (Buxton \& Casler, 1993). Considerable genetic variability exists within all cool-season forage grasses for many of these compounds, but there is no convincing evidence to date which suggests that grazing animals can select plants that are nutritionally better than other plants (Arnold, $1981,1987)$. Snaydon (1978) suggested that natural selection during grazing will select against and, perhaps eliminate, the more palatable genotypes.

Palatability of cool-season forage grasses to ruminants is not related to forage nutritional value per se (Arnold, 1981), but is strongly influenced by specific 
chemical defense mechanisms in some species (Levin, 1976). In reed canarygrass, the concentration of indole alkaloids has a strong negative effect on palatability to sheep (Ovis aries) and cattle (Bos taurus) (Simons \& Marten, 1971; Marten, 1973). Trichomes also may provide grasses with a specific defense mechanism against excessive grazing by ruminants (Levin, 1973). Orchardgrass genotypes are known to possess various degrees of siliceous dentation along their leaf blade margins (Van Dijk, 1959), but the role of these dentations in the evolution of orchardgrass has not been studied. Reed canarygrass genotypes without alkaloids and orchardgrass genotypes without silicious dentations have not yet been discovered or developed, and plants with extremely low levels of these traits are very rare (Marten, 1973; Van Dijk, 1959). Palatability of alkaloid-free reed canarygrass genotypes and siliceous dentation-free orchardgrass genotypes may be so high that these genotypes were unfit to reproduce in grazed grasslands, either sexually or asexually, and they were lost or reduced to extremely low frequencies in natural populations prior to the advent of germplasm collection and plant breeding. The physiological costs of these defense mechanisms are unknown in these two species. In white clover, cyanogenesis apparently carries a cost in reproductive fitness, compared to acyanogenic genotypes (Noitsakis \& Jacquard, 1992).

Companion species in grasslands also may serve to regulate natural selective forces. When planted in common nurseries, sweet vernalgrass plants selected at random from $>50$-yr-old plots containing tall vegetation were up to $50 \%$ taller and more upright in growth habit (Snaydon \& Davies, 1972) and were more tolerant of low levels of photosynthetically active radiation (Davies \& Snaydon, 1976) than plants selected at random from plots containing short vegetation. These changes occurred over distances of $<1 \mathrm{~m}$ (Snaydon, 1973) and occurred despite the low proportion $(<10 \%$ of plot dry matter) of sweet vernalgrass in the plots (Snaydon, 1970). Perennial ryegrass, orchardgrass, sweet vernalgrass, and Yorkshire fog plants selected from plots differing in soil $\mathrm{pH}$ and fertility after $70 \mathrm{yr}$ of natural selection were grown in all possible pairs of binary mixtures (Snaydon, 1978). Populations selected from the same plot had higher yields and were more stable in mixtures with other species selected from the same plot than from species selected from different plots. Evans et al. (1989) also present evidence that populations of perennial ryegrass and white clover, that have coexisted for many years, have higher yield in binary mixture with each other than with other populations.

Finally, there is some evidence that fungi can influence genetic changes during natural selection. Natural selection in the presence of fungal parasites can lead to genetic shifts toward more resistant plants, but only when the environment is favorable for disease development. Sweet vernalgrass plants that survived more than $50 \mathrm{yr}$ of natural selection in plots with tall vegetation were more resistant to yellow leaf rust than those that evolved in plots with short vegetation (Snaydon \& Davies, 1972). Endophytic fungi have formed stable, long-term relationships with some forage grasses, such that infected plants tend to have greater vegetative vigor and tillering capacity and greater tolerance to drought and herbivory (see review by Clay, 1990). Clay (1990) surmises that methodical selec- 
tion for superior vigor and persistence in forage grasses has led to unconscious selection for endophyte-infected plants.

\section{Unconscious Selection}

Under a strict definition of domestication (Isaac, 1970), few cool-season forage grasses are domesticated owing to our inability to visually distinguish cultivated from wild forms. Most cultivated forms of cool-season forage grasses still show various degrees of seed shattering and seed dormancy, traits generally lost or reduced in importance during the domestication of a species (Harlan, 1975; Zohary, 1984). However, shattering resistant or reduced-shattering plants that breed true have been discovered in tall oatgrass (Pfitzenmeyer, 1962), hardinggrass (McWilliam, 1963), and orchardgrass (Love, 1969). Italian ryegrass seems to be an exception to this generalization. Tyler et al. (1987) concluded that European populations of ryegrass represent a "huge hybrid swarm," in which perennial ryegrass and Italian ryegrass represent the opposite extremes of adaptation to grazing vs. infrequent hay harvesting. Italian ryegrass is believed to have been cultivated as a hay crop as early as the twelfth century in irrigated meadows of the Lombardy and Piedmont plains of Italy, where fields were regenerated by occasionally allowing the crop to reseed (Beddows, 1953). Italian ryegrass may represent a genetic adaptation of the twelfth century version of the ryegrass hybrid swarm to a relatively stable and unstressful practice of hay production (Breese \& Tyler, 1986). Hayward et al. (1982) suggested that this agricultural practice would have imposed a uniform, stabilizing selection pressure for a large number of generations. Selection pressure would have increased allele frequencies for seed production traits and those traits that confer an upright and relatively lowtillering growth habit, while maintaining much of the genetic variability from the parent species that is still seen in Italian ryegrass today.

Harlan (1975) defines domestication as evolution under human influences, leaving open the possibility that some species may be considered partly domesticated. Stapledon (1924), Levy (1929), and Gregor and Sansome (1927) all argued that unconscious selection during harvesting and replanting of seed from grass hay fields has acted to genetically modify commercial strains of common cool-season forage grasses, such that they no longer resemble "wild" or true pasture types that would have coevolved with ruminants. Phenotypic changes have probably been toward earlier flowering, larger seeds, a more erect growth habit, and sparser tillering (Stapledon, 1924; Stapledon, 1928; Beddows, 1953). Ellenberg (1963; cited by Scholz, 1975) estimates that the practice of cutting hay from meadows of higher-yielding forage grasses is little more than $1000 \mathrm{yr}$ old. Given the rapid spread of agriculture throughout the temperate world during the past $1000 \mathrm{yr}$ and the rapidity with which genetic changes can be fixed through natural selection and unconscious selection in forage grasses, it is entirely possible that the wild types of some contemporary grasses, i.e., those present in nature prior to this millenium, no longer exist.

The earliest recording of ryegrass in Great Britain, where it was introduced from continental Europe, is 1677 (Beddows, 1953). By 1793, ecotypic differen- 
tiation and the concept of superior strains were evident. William Pacey (a farmer) and William Marshall (perhaps the first grassland ecologist) were the first people to recognize and publicize strains with superior persistence and ostensibly superior forage quality. Persistence was the main distinguishing factor, suggesting that these agriculturists had recognized the two basic forms of the ryegrass hybrid swarm, perennial ryegrass and Italian ryegrass. George Sinclair conducted the first scientific evaluation of ryegrass cultivars, including forage yield measurements and visual ratings of growth habit and reproductive traits, prior to 1816. By 1823 , one seed dealer was reported to have 60 cultivars of perennial ryegrass (Beddows, 1953). By 1856, J.C. Morton recognized that Italian ryegrass contained more variation in plant type than perennial ryegrass. Beddows $(1968,1969$ a, b) also has reviewed early writings on orchardgrass and timothy and, apart from a 1794 reference to William Pacey's interest in propagating a superior strain of orchardgrass (Beddows, 1953), found no evidence of intentions to propagate superior strains of orchardgrass or timothy until the initiation of formal breeding efforts at the Welsh Plant Breeding Station in 1919.

The development of the early flowering timothy strain 'Shelby' appears to be a direct result of unconscious selection. Timothy hay was harvested when the earliest heads were mature and stored in a hay loft. Shattered seed was separated from chaff left behind when all hay was removed from the barn. Seed was replanted or sold to other farmers in this manner from at least 1855 to 1930 (Evans, 1937).

\section{Methodical Selection}

Formal breeding of cool-season forage grasses appears to have begun almost simultaneously between 1889 and 1891 in Great Britain (Beddows, 1953) and the USA (Hays, 1892; Smith, 1948), sometime in the late nineteenth century in Denmark (Frandsen, 1991), and prior to 1907 in Sweden (Witte, 1919). Timothy was an extremely popular forage grass in late nineteenth century USA (Beddows, 1969a), and timothy breeding efforts in Minnesota focused exclusively on selection for traits related to sexual reproduction, with the objective to, "secure a foundation stock of plants with some distinguishing mark," (Hays, 1892).

The earliest scientific reports of cool-season forage grass breeding and genetic studies focused on the characterization of natural variation and potential environmental factors causing this variation (Turesson, 1922; Gregor \& Sansome, 1927; Stapledon, 1928; Levy \& Saxby, 1933). Levy (1932) was the first to recognize the relatively short time period (60-80 yr) in which different plant types of ryegrass may evolve in response to different management practices, climates, and soil types. These and similar results led directly to the development of the first certified forage grass cultivars, for New Zealand in 1930 (Hunt \& Easton, 1989), and for Great Britain in the 1930s (Beddows, 1953). Similarly in Australia, perennial ryegrass introductions, naturalized over 80 to $100 \mathrm{yr}$, were superior to numerous introductions of diverse origin (Moodie, 1934). Considerable progress has been made since then in broadening the adaptation and improving many forage traits of cool-season forage grasses (Hanson, 1972; Barker \& Kalton, 1989; Marten, 1989; Buxton \& Casler, 1993). Despite the progress that has been made 
in $100 \mathrm{yr}$ of cool-season forage grass breeding, germplasm collection in natural habitats and exploitation of natural variation remain a mainstay of breeding programs in nearly all economically important species (e.g., Sachs \& Coulman, 1983; Tyler, 1987; Burner et al., 1988; Casler, 1991). In some cases recently collected germplasm can provide an almost immediate infusion of new and valuable genetic variation. For example, a perennial ryegrass collection from the Zurich Uplands was considered a novel source of alleles for increased forage yield and nutritive value of perennial $\times$ Italian ryegrass hybrids (Jones \& Humphreys, 1993).

\section{Conclusions}

Three selective forces have acted to bring about genetic changes in coolseason forage grasses since the advent of animal farming practices. Natural selection is certainly responsible for the genetic entities that were available to humans $3000 \mathrm{yr}$ ago. Natural selection has continued to create shifts in allele frequency in natural and/or undisturbed populations, causing genetic differentiation as a function of numerous physical and edaphic factors. These factors also may cause relatively short-term genetic changes in pastures, hay fields, and research plots. Because cool-season forage grasses are largely undomesticated, many genetic shifts due to natural selection result in genetic improvements from an agricultural viewpoint. Some natural selection pressures operate more efficiently and effectively in germplasm improvement programs than methodical selection pressures that might be applied. The effects of unconscious selection have been dramatic, but not to the extent observed in annual grain crops (Harlan, 1975). Use of forage crops as feed for animals, rather than humans, is probably responsible for reduced unconscious selection pressure compared to grain crops. Unconscious selection has likely resulted in the development of one new cool-season forage grass species (Italian ryegrass) and numerous strains prior to the onset of methodical selection programs. All three forces remain important in most coolseason forage grass breeding efforts.

\section{SELECTION CRITERIA}

The earliest grass breeding efforts were either formalized continuations of the unconscious selection that humans had practiced for traits related to sexual reproduction (Hays, 1892) or were efforts to capitalize upon natural variation created by ecotype differentiation due to variations in the physical environment or in farming practices (Stapledon, 1928; Levy, 1932). Spaced plantings of seedpropagated collections provided the basis for most initial cultivar development (Levy, 1932; Smith, 1948). Cultivars were created either by increasing seed of natural collections with desirable traits (Levy, 1932) or by selection of individual plants with desired traits (Jenkins, 1943). Individual plant selection was focused on traits such as growth habit, flowering date, and sustained vigor over several years (persistence). The earliest cultivars were mainly classified according to their maturity and use, tall-growing plants were selected for hay types and shorter- 
growing plants were selected for pasture types (Stapledon, 1928; Jenkin, 1943). Most early cultivars contained large amounts of phenotypic variability (Forde \& Suckling, 1980), a considerable portion of which can be attributed to genetic factors (Van Dijk, 1955; Cooper, 1959; Hayward, 1970). Thus, these cultivars were extremely susceptible to genetic shifts during seed multiplication (Evans et al., 1961), but they also were valuable as sources of genetic variability for development of more uniform strains (Cooper, 1959). The remainder of this section will focus on progress achieved through selection in cool-season forage grasses. Numerous selection criteria have been applied to these grasses, but the review will focus on those categories that have had the greatest amount of attention and/ or impact across a range of cool-season forage grasses.

\section{Maturity}

Relative maturity is measured as heading date, anthesis date, or a relative maturity score on a particular calendar date. Historically, it is probably the single most commonly applied selection criterion in breeding cool-season forage grasses. Modern cultivars require parents which are phenotypically similar in relative maturity to maintain adequate seed production, uniform timing of seed maturation, and to be legally protected. Cultivars of most cool-season forage grasses vary in relative maturity of reproductive growth and this variation is often exploited in developing optimum management strategies. For example, late-maturing orchardgrass cultivars tend to be less persistent in mixture with alfalfa than early maturing cultivars (Casler, 1988; Casler \& Walgenbach, 1990). In perennial ryegrass, late-heading lines were more tolerant of freezing than early heading lines (Humphreys \& Eagles, 1988). When harvested in a given calendar date, late-maturity cultivars have higher forage nutritive value for reproductive growth and sometimes for vegetative growth than early maturity cultivars (Casler, 1990).

Maturity is highly heritable and readily amenable to modification by selection, despite generally being considered to be polygenically inherited (Cooper, 1959, 1960; McLean \& Watson, 1992). Three cycles of phenotypic selection for divergent maturity in two perennial ryegrass populations led to variation far exceeding that of the original populations (Cooper, 1959, 1960). Selection responses toward lateness were greater than toward earliness, prompting Cooper (1959) to suggest that early genotypes might be more heterozygous, displaying more nonadditive genetic effects which could not be captured by the breeding system. McLean and Watson (1992) observed similar results in an early maturity Italian ryegrass cultivar (Florida 80), but the opposite asymmetry of response in their latest-maturing cultivar (Marshall), and no asymmetry in a medium-maturity cultivar, Gulf (Fig. 14-2). They speculated that low winter temperatures may provide an environmental barrier to selection for earliness in the already early maturity Florida 80, while high summer temperature and drought may restrict pollination and fertilization in extremely late-maturing plants, effectively restricting progress for lateness in the already late-maturity Marshall. They also indicated that the effectiveness of selection for earliness vs. lateness depends on the latitude at which selection is practiced. 


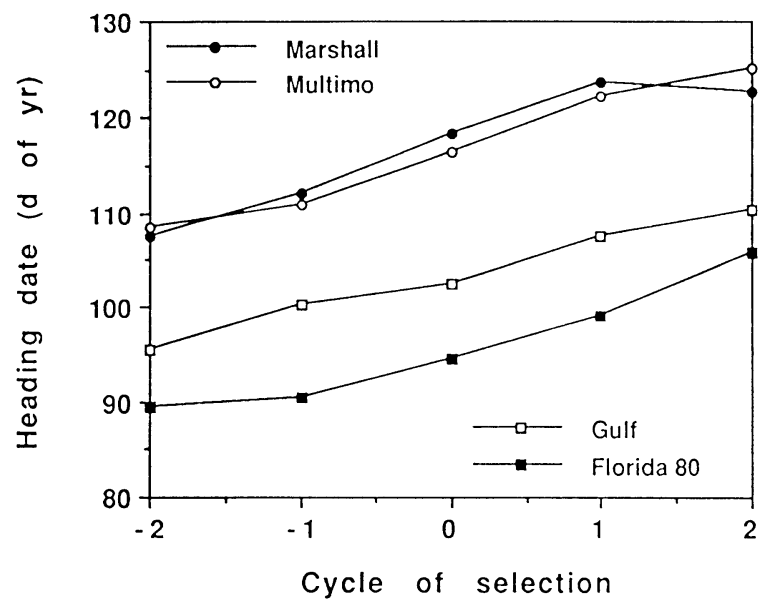

Fig. 14-2. Effect of two cycles of selection for early heading date (negative cycle numbers) or late heading date (positive cycle numbers) in four populations of Italian ryegrass (adapted from McLean \& Watson, 1992).

\section{Forage Yield and Vigor in Monoculture}

While many researchers have studied the inheritance and genetic variation for forage yield of cool-season grasses (see reviews of Hanson \& Carnahan, 1956; Smith, 1956), there are few published reports that document the effects of selection for forage yield per se (Barker \& Kalton, 1989). Forage yield can be improved by selection (Frandsen, 1949; Carlson, 1985; Carlson, 1990), but few published studies include the proper controls to document the improvement in forage yield associated specifically with selection efforts. Selection for increased spaced-plant forage yield was successful, but highly variable in four of six perennial ryegrass populations (Hayward, 1983). Despite realized heritability of only 0.13 in another perennial ryegrass population, divergent selection for spacedplant forage yield resulted in a high-yield population with $88 \%$ higher yield than the low-yield population (Ceccarelli et al., 1980). However, spaced-plant yield generally has not been useful in predicting forage yield of swards for perennial ryegrass (Petersen, 1976; Hayward \& Vivero, 1984) and several other species (Rotili et al., 1976; Casler \& Hovin, 1985; Carpenter \& Casler, 1990). Genetic gains made under spaced-plant conditions were decreased as the interplant spacing was decreased in evaluation experiments (Hayward \& Vivero, 1984). Similarly, in reed canarygrass and smooth bromegrass, selection for increased spacedplant forage yield did not consistently result in increased yield per unit land area (Surprenant et al., 1988; Carpenter \& Casler, 1990). Narrow spacings (8 or 23 $\mathrm{cm}$ ) may have more potential for yield selection than wider spacings (Lazenby \& Rogers, 1964). Only two exceptions have been reported among cool-season forage grasses.

Four cycles of phenotypic selection were used to increase forage yield in 'Wrens Abruzzi' rye (Bruckner et al., 1991). Gain per cycle was 6 to $7 \%$ for the spaced-plant evaluation and 2 to $3 \%$ for the small-plot evaluation. Selection was 
based exclusively on visual ratings of vigor, growth habit, and disease resistance of single plants spaced $45 \mathrm{~cm}$ apart.

Three cycles of selection for high spaced-plant forage yield in Italian ryegrass gave 73 and $81 \%$ increase in two adapted cultivars and a $37 \%$ increase in an unadapted cultivar when tested as spaced plants (Fujimoto \& Suzuki, 1975). Yield selection increased mean plant height and tiller number and decreased heading date in all three cultivars. The first two cycles of selection resulted in 3.3 to $7.2 \%$ higher total sward-plot forage yield than the respective parent cultivars and a synthetic population had 4.5 to $12.2 \%$ higher total sward-plot forage yield than the three parent cultivars.

Apart from these examples of direct selection for yield, most forage yield improvements in cool-season grasses have been made using one of two general approaches. First, selection among advanced generation synthetics on the basis of forage yield may be the most common use of forage yield as a selection criterion. Many breeding schemes emphasize distinct morphological trait goals, superior vigor, and uniformity among parental clones for the purpose of cultivar protection and use little or no selection pressure for yield until advanced generations of synthetic populations are ready for field testing. Because most cultivars of cool-season forage grasses are synthetics, they are subject to inbreeding depression during generation advance, and may often not differ from their original population in mean performance. When a synthetic cultivar is to be the final product of the breeding program, Gallais (1992) recommends that breeders concentrate their efforts on recurrent selection rather than selection among narrowbased synthetics, to make the most efficient progress for the economic trait.

Second, selection for specific modifications to morphological or physiological traits can be used to improve forage yield. In reed canarygrass, two cycles of divergent selection for specific leaf weight (SLW) led to dramatic changes in plant morphology compared to the base population (Table 14-1). The high SLW population was 3\% higher, while the low SLW population was $4 \%$ lower than the base population in forage yield measured on sward plots (Carlson, 1990). Extreme modification of plant morphology by breeding can induce genotype $\times$ management interactions. Divergent selection for leaf length in perennial ryegrass resulted in a long-leaf population that had $14 \%$ higher forage yield than a shortleaf population under infrequent cutting of sward plots (Table 14-2). Conversely, under frequent cutting, the long-leaf population had $12 \%$ lower forage yield than the short-leaf population. High yield was associated with high leaf area index

Table 14-1. Mean values for morphological traits of a reed canarygrass base population

(NCRC1) and second-cycle populations selected for divergent specific leaf weight, SLW (Carlson et al., 1983).

\begin{tabular}{lccccc}
\hline Population & $\begin{array}{c}\text { Specific } \\
\text { leaf weight }\end{array}$ & $\begin{array}{c}\text { Leaf } \\
\text { thickness }\end{array}$ & $\begin{array}{c}\text { Tiller } \\
\text { number }\end{array}$ & $\begin{array}{c}\text { Tiller } \\
\text { dry weight }\end{array}$ & Plant height \\
\hline & $\mathrm{g} \mathrm{m}^{-2}$ & $\mathrm{~mm}$ & plant $^{-1}$ & $\mathrm{~g}$ & $\mathrm{~cm}$ \\
High-SLW (C2) & 57.7 & 0.234 & 124 & 1.17 & 164 \\
NCRC1 & 45.7 & 0.193 & 169 & 0.89 & 154 \\
Low-SLW (C2) & 36.3 & 0.162 & 200 & 0.64 & 143 \\
LSD (0.05) & 1.6 & 0.007 & 15 & 0.09 & 5 \\
\hline
\end{tabular}


(LAI) at nearly complete light interception and a low light extinction coefficient $\left(K_{\text {vis }}\right)$ under infrequent cutting, but with high LAI of the basal portion of the canopy and high $\mathrm{K}_{\mathrm{vis}}$ under frequent cutting (Rhodes, 1971). The positive association of leaf length and forage yield under infrequent cutting was strong and consistent for Italian ryegrass and Italian ryegrass $\times$ perennial ryegrass crosses, but was low and inconsistent for perennial ryegrass populations (Rhodes, 1975). Regrowth forage yield in tall fescue was 38 and $24 \%$ higher in swards of a highleaf area expansion rate (LAER) population than in swards of a low-LAER population under infrequent and frequent cutting, respectively (Table 14-2). Reproductive-growth forage yield under infrequent cutting was unaffected by selection, whereas reproductive-growth forage yield under frequent cutting was reduced by selection for high LAER.

Selection for increased leaf photosynthesis has not been effective in increasing forage yield, because leaf size and photosynthesis per leaf area are often negatively correlated (Wilson, 1984). Conversely, divergent selection for mesophyll cell size in perennial ryegrass had a measurable effect on forage yield (Wilson \& Cooper, 1970). The population with smaller mesophyll cells had $36 \%$ smaller mesophyll cells, $18 \%$ thinner mesophyll layer, $28 \%$ heavier seed size, $12 \%$ higher net assimilation rate, $11 \%$ lower leaf area ratio, $15 \%$ lower relative leaf growth rate, and $42 \%$ higher forage yield than the population with larger mesophyll cells. Because leaf size and mesophyll cell frequency did not change with selection, Wilson and Cooper (1970) concluded that this selection criterion should be useful in selecting plants that have both an increased leaf size and higher photosynthetic rate per leaf area.

Divergent selection for mature-tissue dark respiration rate of perennial ryegrass leaves resulted in slow-respiring populations with 20 to $34 \%$ lower mature-tissue dark respiration rate than the fast-respiring populations (Robson, 1982a; Wilson, 1982). The slow-respiration population produced more dry matter for the same cost in $\mathrm{CO}_{2}$ respired per unit ground area (Robson, 1982a). Robson $(1982 a, b)$ attributed half of this savings to more economic use of $\mathrm{C}$ and half to a

Table 14-2. Forage yields (on a dry matter basis) of perennial ryegrass populations selected for long or short leaf length and tall fescue populations selected for high or low leaf area expansion rate (LAER), harvested on an infrequent and a frequent schedule.

\begin{tabular}{|c|c|c|c|c|}
\hline \multirow[b]{2}{*}{$\begin{array}{l}\text { Harvest frequency/ } \\
\text { Population } \dagger\end{array}$} & \multirow[b]{2}{*}{$\begin{array}{c}\text { Perennial } \\
\text { ryegrass total } \ddagger\end{array}$} & \multicolumn{3}{|c|}{ Tall fescue $\S$} \\
\hline & & $\begin{array}{l}\text { Reproductive } \\
\text { growth }\end{array}$ & $\begin{array}{l}\text { Vegetative } \\
\text { growth }\end{array}$ & Total \\
\hline & & $\mathrm{Mg} \mathrm{ha}^{-1}$ & & \\
\hline \multicolumn{5}{|l|}{ Infrequent } \\
\hline Long (high) & 12.62 & 4.35 & 1.87 & 6.22 \\
\hline Short (low) & 11.11 & 4.16 & 1.36 & 5.52 \\
\hline \multicolumn{5}{|l|}{ Frequent } \\
\hline Long (high) & 8.76 & 2.97 & 2.41 & 5.38 \\
\hline Short (low) & 9.71 & 3.66 & 1.95 & 5.61 \\
\hline
\end{tabular}

$\dagger$ Long/short refer to leaf length of perennial ryegrass populations, high/low refer to LAER of tall fescue populations.

$\ddagger$ Adapted from Rhodes, 1969 .

$\S$ Adapted from Sleper and Nelson, 1989. 
$25 \%$ greater adult-plant tiller number in the slow-respiration population. In two field trials, synthetics selected for a slow-respiration rate had forage yields consistently higher than the base population, with a 5.6 to $12.8 \%$ increase under a frequent harvest management and a 5.2 to $12.9 \%$ increase under an infrequent harvest management (Wilson \& Jones, 1982). The greatest yield advantage of the slow respiring populations was observed under the warmest conditions, when respiration rates are expected to be higher.

In orchardgrass, divergent selection for leaf tensile strength led to a $20 \%$ difference in leaf strength between high and low populations (Wilson \& Jones, 1981). The high leaf strength population had higher yield than the low leaf strength population, $9 \%$ under infrequent harvest and $5 \%$ under frequent harvest.

Trupp and Carlson (1971) increased mean seed weight of smooth bromegrass by $30 \%$ over three cycles of recurrent selection. The higher seed weight populations had higher germination percentages and mean seedling weight up to $39 \mathrm{~d}$ after planting. All effects of selection for higher seed weight on seedling vigor or forage yield had disappeared by $62 \mathrm{~d}$ after planting (Jessen \& Carlson, 1985; Trupp \& Carlson, 1971). Three cycles of divergent selection for a speedof-germination index in Altai wildrye (high $=21.5$ vs. low $=5.9$ ), resulted in significant differences in stand establishment ( 85 vs. $76 \%$, respectively) (Lawrence, 1977). Two-year total forage yield was lower for the slow-germinating population, but there was no difference in yield when stand establishment was equalized, suggesting that selection did not affect forage yield per se.

\section{Forage Yield and Persistence in Mixture With Legumes}

Stapledon (1924) was the first scientist to describe the poor potential for commonly cultivated types of orchardgrass and perennial ryegrass (early flowering, erect, and sparse-tillering) to form productive mixtures with white clover. He suggested instead, "that the Perennial Rye Grass cleaned out of Kentish Wild White Clover represents a very valuable and leafy form well suited for the establishment of permanent pastures...." Long-term, coexisting perennial ryegrasswhite clover populations have higher total forage yield and clover yield than noncoexisting mixtures when evaluated in common nurseries (Evans et al., 1989). A perennial ryegrass population selected for long, rigid leaves and erect tillers had higher yield in mixture with white clover, without reducing clover yield, compared to a cultivar without these traits (Evans et al., 1989).

In a review of a series of grass-legume competition experiments, Zannone et al. (1986) concluded that identification of superior cultivars for grass-legume associations does not require mixed-stand evaluations. The grass-legume associations with the highest forage yield and persistence were those in which the grass and legume cultivars both were high in vigor and the grass cultivar was extremely early in maturity, as measured in monoculture. Jones et al. (1989) reached a similar conclusion about optimal reed canarygrass phenotypes for compatability with two perennial legumes. Most studies support the contention that grass cultivar vigor is highly correlated between mixed stands and monocultures (Churchill, 1947; Wilsie, 1949; Weiss \& Mukerji, 1950; Schmidt \& Tenpas, 1965; Krueger \& Scholl, 1970). 
Changes in harvest management may change the relationship between flowering date and performance of grass cultivars in mixture with alfalfa. An early flowering timothy cultivar had vigor superior to later-flowering cultivars in infrequently harvested mixtures, but was inferior in frequently harvested mixtures (Smith et al., 1973). Persistence of ryegrass cultivars in mixture with alfalfa is not related to their relative maturity (Casler, 1988; Casler \& Walgenbach, 1990), but later-flowering orchardgrass cultivars had the lowest vigor, regrowth, and persistence within a diverse group of 40 cultivars grown in mixture with alfalfa (Casler, 1988). Likewise, selection for reduced canopy height, decreased tiller number, and delayed maturity led to orchardgrass populations more compatible with birdsfoot trefoil than populations derived by selection in the opposite direction, as measured by birdsfoot trefoil yield in mixture (Short \& Carlson, 1989). In tall fescue-birdsfoot trefoil mixtures based on tall fescue populations differing in LAER (Sleper \& Nelson, 1989), birdsfoot trefoil forage yields did not differ among mixtures and tall fescue forage yields were highly correlated between mixtures and monocultures (Nelson et al., 1989).

Selection of progenies persisting in competitive, interspecific mixtures led to populations with faster and greater regrowth in smooth bromegrass (Table 14-3) and perennial ryegrass (Van Dijk, 1983). In the smooth bromegrass study, ground cover also was increased by an average of $76 \%$. A similar selection protocol, employed by Novy et al. (1995) in intermediate ryegrass and perennial ryegrass, led to populations with greater contributions to grass-legume mixture yield (a genetic increase of 53 and $82 \mathrm{~g}$ grass dry matter $\mathrm{kg}^{-1}$ total dry matter, respectively). The relative ranking among cultivars, for persistence in mixture with alfalfa, appears to be a function of latitude in smooth bromegrass and tall fescue, and of soil type in timothy (Casler \& Walgenbach, 1990). These interactions and the population responses of sweet vernalgrass to differences in soil $\mathrm{pH}$ and fertility (Snaydon, 1978) suggest that environmental variation may result in large differences among genotypes which are selected from forage mixtures. In sweet vernalgrass, genetic variation was greatest in environments that were most variable from year-to-year (Snaydon, 1973) and selection pressure for persistence was greatest in plots with the tallest vegetation and highest yield (Davies \&

Table 14-3. Three-year mean vigor and recovery of smooth bromegrass populations selected or not selected for increased persistence in mixtures with alfalfa and evaluated in similar mixtures, adapted from Casler (1988).

\begin{tabular}{llcr}
\hline & \multicolumn{3}{c}{ Harvest } \\
\cline { 2 - 3 } Population & 1 & 2 & 3 \\
\cline { 2 - 3 } & \multicolumn{2}{c}{ Vigor: mean height above alfalfa canopy } \\
Not selected & 13 & 4 & 1 \\
Selected $\dagger$ & 17 & 5 & 2 \\
& \multicolumn{2}{c}{ Recovery: mean height 2 wk after harvest } \\
Not selected & 7 & 5 & 7 \\
Selected $\dagger$ & 9 & 8 & 10 \\
\hline
\end{tabular}

† Selected vs. not selected different at $P<0.01$ for all six pairs. 
Snaydon, 1976). Coexisting crop species or populations may influence the genetic shifts of populations under natural selection pressure (Evans et al., 1989).

\section{Biotic Stresses}

Biotic stresses on forage grasses include diseases, nematodes, insects, and herbivores. Because the interactions of herbivores with grass genetics and breeding systems have been reviewed earlier, this section will focus on pests.

\section{Diseases}

Resistance to diseases has been an important component of many coolseason forage grass breeding programs since it was first learned that resistance to timothy rust could be improved by selecting plants with relatively minor symptoms (Webber, 1912; Witte, 1919). Braverman (1986) recently reviewed the literature on the inheritance of resistance to most important disease organisms in the economically important cool-season forage grasses. The review includes a summary of the effects of disease infection on forage yield and nutritive value, a summary of the inheritance of resistance to some diseases, and numerous lists of resistant or partially resistant cultivars. Enhanced resistance to diseases in coolseason forage grasses, obtained by breeding, can improve forage yield and nutritive value in the presence of disease organisms (Catherall, 1987; Karn et al., 1989), but has little or no influence on forage yield and nutritive value when the pathogen is absent (Hides \& Wilkins, 1978; Catherall, 1987; Oberheim et al., 1987), suggesting that polygenic disease resistance has little or no physiological cost.

Two host-parasite complexes appear most frequently in cool-season forage grass breeding literature: stem rust of orchardgrass and crown rust of ryegrasses. Inheritance of resistance in both cases is complicated by genetic interactions between the host and the pathogen (reviewed by Braverman, 1986). Single genes, dominant for resistance to specific races of the pathogen and with relatively large effects, have been found in both grass genera. In both cases, there also is a considerable amount of genetic variation apparently due to numerous genes with small additive or additive and dominant effects (Hayward, 1977; Miller \& Carlson, 1982).

Quantification of progress made in breeding for disease resistance is extremely difficult. Many resistant cultivars and populations derive from numerous and diverse sources and cannot be compared to their source populations per se in uniform experiments. Intrapopulation selection, and subsequent evaluation of progress, provides the best documentation of the effects of selection on changes in disease resistance. Intrapopulation improvement has been documented for resistance to stem rust of orchardgrass (Miller \& Carlson, 1982), purple leaf spot of orchardgrass (Zeiders et al., 1984), brown leaf spot of smooth bromegrass (Jessen \& Carlson, 1985; Jessen et al., 1983; Berg et al., 1986), leaf spot of smooth bromegrass (Smith \& Knowles, 1967), leaf blight of tall fescue (Smith et al., 1986), crown rust of Italian ryegrass (Hides \& Wilkins, 1978; Mansat \& Betin, 1979), ryegrass mosaic virus (RMV) of Italian ryegrass (Hides \& Wilkins, 1978), 
and leaf spot of intermediate wheatgrass (Krupinsky \& Berdahl, 1982). Both crown and stem rust resistance of orchardgrass increased during two cycles of selection for seed and forage traits, apparently due to improved plant vigor, because rust resistance was only a minor selection criterion (Berg et al., 1993).

Both selection studies for crown rust resistance in Italian ryegrass were based on artificial inoculation in the glasshouse and included at least eight source populations. Selection progress, as measured in the glasshouse, varied among source populations in both studies. Although artificial inoculation in the glasshouse was necessary to estimate direct response to selection, it overestimated genetic progress under natural inoculation in the field by up to $400 \%$ for RMV of Italian ryegrass (Hides \& Wilkins, 1978) and by up to $218 \%$ for crown rust of diploid Italian ryegrass (Mansat \& Betin, 1979). For tetraploid Italian ryegrass, selection progress under natural inoculation in the field corresponded well with results from artificial inoculation in the glasshouse. Field screening with natural inoculation also has been successful in some selection studies (Smith \& Knowles, 1967; Miller \& Carlson, 1982; Jessen et al., 1983). Miller and Carlson (1982) demonstrated that natural inoculum of the stem rust pathogen can be genetically diverse, both within and between seasons. They warned that genetic diversity of orchardgrass germplasm source should be maximized for development of effective rust resistance.

Wilkins (1991) inferred that a considerable amount of genetic variation is maintained in wild grass populations by frequency-dependent selection. Increasing the frequency of particular alleles reduces their value, because of evolution in the pathogen population (Wilkins, 1991). In perennial ryegrass, the crown rust pathogen is capable of rapid evolution to overcome a high degree of host-plant resistance (Wilkins, 1978). Moderate resistance was more stable than a high degree of resistance. Wilkins $(1978,1991)$ surmised that the high degree of genetic diversity within most grass populations and the use of recurrent selection in the field (to preserve genetic diversity and expose populations to a wide array of pathogen genotypes) are responsible for the relative stability of disease resistance in most breeding programs and their cultivars. He also indicated that polygenic resistance to crown rust in ryegrass is widespread (Wilkins, 1975).

York and Cook (1989) selected perennial and Italian ryegrass plants for resistance to root-knot nematode. Although the genetics of host-plant resistance have yet to be reported, most plants classified as resistant or susceptible, on the basis of gall number in an unreplicated screening, maintained their original classification in a second screening. The authors felt that the large selection differentials implied that host-plant resistance is a component of this phenotypic variation. Selection differentials in the second screening varied widely among seven cultivars, suggesting that selection will not be equally effective in all germplasm sources.

\section{Insects}

Insect pests have received considerably less attention by grass breeders and their associates than disease pests, in part, due to a general perception that they are less serious and that screening techniques are more variable and difficult 
to control. The only reports of enhanced insect resistance due specifically to selection and breeding of cool-season forage grasses are a result of unconscious selection. Reduced cellulose concentration in perennial ryegrass was associated with reduced feeding and damage by stem weevil, and reduced pupation by housefly larvae (Lancashire et al., 1977). Also in perennial ryegrass, selection for decreased epidermal ridging of leaves created an environment apparently less acceptable to mites, which may transmit ryegrass mosaic virus (Chamberlain \& Evans, 1979).

Several species of Triticeae grasses showed varying levels of damage and reproduction by Russian wheat aphid, but intraspecific variation for damage was clearly demonstrated only in quackgrass (Kindler et al., 1991). The study provided strong evidence that the de facto resistance of quackgrass $\times$ bluebunch wheatgrass hybrid derivatives was contributed by the quackgrass genome. Variation also has been shown for feeding damage among Triticeae tribe genomes (grass bug, Hewitt, 1980; bluegrass billbug, Nielson et al., 1993) or reed canarygrass genotypes (frit fly, Byers \& Sherwood, 1979). In the latter two studies, the authors suggested factors apparently involved in host-plant resistance: a rhizomatous phenotype and the presence of the J, N, or P genome in the Triticeae tribe; high tiller density and/or alkaloid concentration in reed canarygrass. In both studies the authors were optimistic about the prospects for selecting genotypes with superior host-plant resistance.

\section{Abiotic Stresses}

Most genetic progress made toward abiotic stress resistance has been during the process of proprietary cultivar development and, as such, is not well documented. Many documented gains in cool-season forage grasses are the result of natural selection, either used directly by increasing superior ecotypes as a cultivar, or incorporated into the breeding program through specific selection protocols. Field screening protocols can be highly variable, unrepeatable, and difficult to define. Laboratory conditions may not suffer from these negative aspects, but may require expensive equipment and time-consuming assays, and are still subject to a field evaluation of progress.

\section{Cold Temperature}

Cold or freezing tolerance is probably the abiotic stress which has received the most attention for perennial grasses of temperate climates. Development of specific screening procedures for breeding programs is complicated by other factors affecting winter survival, such as hardening/dehardening conditions (Gay \& Eagles, 1991). Freezing tolerance also can break down, for example, upon prolonged exposure of perennial ryegrass to high concentrations of atmospheric $\mathrm{SO}_{2}$ (Davison \& Bailey, 1982). Selection for high water soluble carbohydrate (WSC) concentration increased cold tolerance in perennial ryegrass (Breese \& Foster, 1971), but not all genetic variation for cold tolerance is associated with WSC concentration (Hides, 1978). Humphreys (1989a) measured 13 additional traits of 86 perennial ryegrass accessions and found their relationships to freezing tol- 
erance to be complex, with relatively small effects of each individual trait on freezing tolerance per se.

Cold or freezing tolerance can often be obtained by collection, testing, and selection of accessions or cultivars from appropriate climates (e.g., Badoux, 1979; Klebesadel \& Helm, 1986). Orchardgrass accessions grown at a low altitude site showed increasing winter survival with higher altitude of the collection site (Badoux, 1979). The relationship broke down for the highest altitude collections, suggesting that these accessions were intolerant of low temperature stress when snow cover was absent. Humphreys and Eagles (1988) and Tcacenco et al. (1989) developed a cold tolerance test for perennial ryegrass which measures the lethal temperature for $50 \%$ of the tillers on a plant $\left(\mathrm{LT}_{50}\right)$. Values of $\mathrm{LT}_{50}$ were positively correlated with the mean temperature of the coldest month at the site of accession origin for both studies and with sward persistence following three winters in the latter study. In tall fescue, genome size [amount of heterochromatin and frequency of repeated deoxyribonucleic acid (DNA) sequences] was positively correlated with latitude of origin, suggesting that structural changes in DNA may play a role in environmental adaptation (Ceccarelli et al., 1992).

Hides (1979) selected for increased cold tolerance (percentage tiller survival at low temperature) in nine Italian ryegrass cultivars. Two cycles of selection reduced tiller mortality by 1 to $50 \%$, with a mean of $19 \%$. However, when populations were field tested, plant survival decreased due to selection in six of the nine cultivars, from $74 \%$ in the original cultivars to $68 \%$ in the selection populations, averaged over all cultivars. Over eight harvests, the effect of selection on forage yield gradually decreased from $+14 \%$ to $-18 \%$. Because selection was conducted on seedlings, the procedure may have favored more vigorous seedlings which were shorter-lived as adults (Hides, 1979).

\section{Air Pollutants}

Natural selection in several grass species has evolved $\mathrm{SO}_{2}$-tolerant populations in regions where $\mathrm{SO}_{2}$ pollution from power plants has been prevalent for numerous years. In some cases, tolerance to acute $\mathrm{SO}_{2}$ injury (as measured by percentage leaf tissue destroyed or dry matter reduction upon short-term exposure to high levels of $\mathrm{SO}_{2}$ ) has evolved within 3 to $5 \mathrm{yr}$ of establishment at polluted sites (Wilson \& Bell, 1985). In red fescue (Wilson \& Bell, 1986) and perennial ryegrass (Horsman et al., 1979), tolerance to acute $\mathrm{SO}_{2}$ injury evolved in direct proportion to selection pressures, as determined by recorded $\mathrm{SO}_{2}$ pollution levels. There is conflicting evidence as to whether alleles for $\mathrm{SO}_{2}$ tolerance carry any deleterious effects. In $\mathrm{SO}_{2}$-tolerant populations of perennial ryegrass, timothy, and Kentucky bluegrass from Phillips Park, tolerance to acute $\mathrm{SO}_{2}$ injury was reduced within 1 to $2 \mathrm{yr}$ after ambient $\mathrm{SO}_{2}$ pollution had dramatically declined (Wilson \& Bell, 1986). Conversely, $\mathrm{SO}_{2}$-tolerant populations of perennial ryegrass were identified in the Liverpool area despite drastic reductions in mean ambient $\mathrm{SO}_{2}$ levels for the 10 to 15 yr prior to collection (Horsman et al., 1979). In the only assessment of heritable variation for $\mathrm{SO}_{2}$ tolerance of a grass species to date, Wilson and Bell (1990) showed that tolerance to acute $\mathrm{SO}_{2}$ injury is heritable in perennial ryegrass, with relatively few genes involved and dominance or partial dominance toward susceptibility. 
A population of orchardgrass, exposed long-term to high levels of atmospheric $\mathrm{SO}_{2}$ and $\mathrm{NO}_{2}$ at Rainham, appeared to have evolved tolerance to acute levels of $\mathrm{NO}_{2}$ alone and an $\mathrm{NO}_{2} / \mathrm{SO}_{2}$ mixture (Taylor \& Bell, 1988). In the same study, perennial ryegrass plants from Rainham appeared to have developed a mechanism for preferential utilization of atmospheric $\mathrm{NO}_{2}$ as a source of nutritional N. Rainham plants had less dead shoot dry matter and a lower dead/live shoot ratio than nontolerant plants under chronic $\mathrm{NO}_{2}$ levels (long-term exposure to relatively low ambient concentrations). Thus, populations which have evolved tolerance to $\mathrm{NO}_{2}$ also may have evolved a dependence on atmospheric $\mathrm{NO}_{2}$, the result of which could be reduced fitness under nonpolluted conditions.

Differences between plants collected at $\mathrm{SO}_{2}$ polluted sites and bred cultivars of four species were consistent when evaluated under both acute and chronic $\mathrm{SO}_{2}$ levels (Bell et al., 1982). Despite the coincidence of tolerance to both acute and chronic injury in these natural populations, acute and chronic injury to $\mathrm{SO}_{2}$ (Bell et al., 1982) and $\mathrm{NO}_{2}$ (Taylor \& Bell, 1988) are uncorrelated on an individual plant basis. Indeed, avoidance mechanisms seem to be responsible for tolerance to acute injury in several species, while tolerance to chronic injury appears to be based on internal mechanisms (Ayazloo et al., 1982). Breeding programs aimed at tolerance to air pollutants may need to carefully address the issue of acute vs. chronic injury.

\section{Drought}

There has been considerable effort devoted to development of effective selection criteria for drought tolerance, a subject recently reviewed by Johnson and Asay (1993). Although numerous selection criteria have been developed and some tested for genetic variability, very few have been subjected to directional selection pressures and subsequently been tested for genetic response in coolseason forage grasses. Grain crops are exceptions to this, but will not be covered in this chapter.

Asay and Johnson (1980) and Berdahl and Barker (1984) both concluded that selection for high emergence from deep planting $(5 \mathrm{~cm})$ and high seed weight should be successful in Russian wildrye. Both studies showed positive correlations between these two variables and field emergence percentages and both were conducted with the goal of enhancing drought avoidance of seedlings during stand establishment. Four cycles of mass selection for emergence vigor from a $5-\mathrm{cm}$ planting depth resulted in a 175 to $254 \%$ increase in emergence percentage from a 5-cm planting depth over that of the original cultivar, Sawki Russian wildrye (Lawrence, 1979). Field emergence increased by $70 \%$ over Sawki in one trial, while establishment year forage yield increased $26 \%$ over Sawki, averaged over five trials, including both dryland and irrigated sites.

Two cycles of selection in perennial ryegrass were used to create two pairs of populations differing in stomatal resistance, $r_{\mathrm{s}}$ (Wilson, 1975a). Populations with long vs. short stomatal length ( $32.5 \mathrm{vs.} 24.4 \mu \mathrm{m}$ ) had $r_{\mathrm{s}}=4.4$ and $5.6 \mathrm{~s} \mathrm{~cm}^{-1}$, respectively, while those with frequent vs. infrequent stomata (124.5 vs. 85.2 $\mathrm{mm}^{-2}$ ) had $r_{\mathrm{s}}=4.7 \mathrm{vs.} 6.9 \mathrm{~s} \mathrm{~cm}^{-1}$, respectively. Upon deprivation of water, leaf extension rates declined more rapidly in the long stomata and the frequent stomata populations compared to their counterpart populations. Wilson (1975a) con- 
cluded that plants with low $r_{\mathrm{s}}$ : (i) used water more rapidly than those with high $r_{\mathrm{s}}$ and (ii) can be obtained either by selection for short or infrequent stomata, although selection for low stomatal frequency was the most effective means used in this study. Using the same base population ('Grasslands Ruanui') as in the above study, Wilson (1975b) also conducted two cycles of selection for deep vs. shallow epidermal ridging on the adaxial leaf surface. Deep- vs. shallow-ridged populations had $r_{\mathrm{s}}=4.4 \mathrm{vs} .5 .6 \mathrm{~s} \mathrm{~cm}^{-1}$. Plants from the shallow-ridged population were better able to save water during drought compared to plants from the deep-ridged population. Because epidermal ridging tended to affect transpiration more during the driest portion of the drought period, Wilson (1975b) concluded that reduced epidermal ridging and reduced stomatal frequency represent different strategies for water conservation, further suggesting that both traits could be combined for maximum protection.

Gay (1989) selected perennial ryegrass plants for divergent leaf water conductance (LWC). Although no progeny were produced in this study, repeatability of the LWC measurement was high, with high- vs. low group means maintaining 38 to $81 \%$ of their original divergence upon two subsequent evaluations. Variation in LWC was not related to stomatal length or frequency or to leaf or tiller growth rates (Gay, 1986). Both low-LWC plants and shallow-ridged plants maintained higher soil moisture at a $12-\mathrm{cm}$ depth during a 6-wk drought $(9-23 \%$ and $6-32 \%$ higher than the original population for low LWC and shallow ridges, respectively) (Wilson, 1976). Both populations also had a 19 to $25 \%$ higher crop growth rate than the base population.

Thomas and Evans (1989) conducted one cycle of selection for high vs. low osmotic potential $\left(\psi_{\mathrm{s}}\right)$ in perennial ryegrass. The low $\psi_{\mathrm{s}}$ population had $9 \%$ lower $\psi_{s}, 3 \%$ lower transpiration rate, $24 \%$ lower wilt score, and $10 \%$ fewer tillers than the high $\psi_{\mathrm{s}}$ population. The two populations did not differ in forage yield, accumulated during drought or upon rewatering, nor did they differ in mean growth rate or leaf extension rate during drought (Thomas \& Evans, 1991).

Based on prior knowledge of correlations between high water-use efficiency (WUE) and low values of the $\mathrm{C}$ isotope $\left({ }^{13} \mathrm{C}\right.$ vs. $\left.{ }^{12} \mathrm{C}\right)$ discrimination ratio $(\Delta)$, Read et al. (1993) conducted divergent selection for $\Delta$ in standard crested wheatgrass. Realized heritability for $\Delta$ was 0.8 and genetic progress was symmetrical, approximately $2 \%$ in each direction. Low- $\Delta$ progenies had $16 \%$ lower $\mathrm{CO}_{2}$ exchange rate, $30 \%$ lower stomatal conductance, $22 \%$ lower transpiration rate, and $19 \%$ higher WUE than high- $\Delta$ progenies. Divergent selection for $\Delta$ did not alter forage yield in the field conditions of northern Utah for either the parental or progeny generations.

Natural selection also may play a role in improving drought tolerance. Some Algerian perennial ryegrass accessions had higher forage yield following drought than locally grown cultivars in Victoria, Australia (Reed et al., 1987). The relatively low yield of Algerian accessions when water was more available, pointed out their narrow range of adaptation and suggested that efforts to transfer their drought tolerance to adapted germplasm will likely require large populations and intensive efforts, if indeed the apparent linkage between these two traits can be broken. Wedderburn et al. (1990) similarly reported perennial ryegrass collections from sites which were more subject to drought stress to have lower leaf 
area, fewer tillers, and lower forage production upon rewatering than collections from sites which were less subject to drought stress. They concluded that germplasm collected from the drier habitats had little value in developing superior cultivars for sites which are not consistently subject to drought. However, they also indicated that some plants fell within the upper $10 \%$ of the yield distribution for both stressed and nonstressed conditions, again suggesting that the apparent linkage between drought tolerance and narrow adaptation may be broken by intensive breeding efforts.

Selected populations were compared to wild or naturally occurring populations of seven species found in low fertility areas of New Zealand (Wedderburn et al., 1993). Although selection did not involve a drought tolerance evaluation per se, selected populations of five species (crested dogstail, colonial bentgrass, Yorkshire fog, sweet vernalgrass, and orchardgrass) had superior recovery from drought following rewatering than did their respective wild populations. Selected and wild populations generally had similar forage yields under nondroughtstressed conditions. The authors concluded that the improved drought recovery of the selected populations was due to traits which were not immediately obvious.

\section{Salinity}

Natural variation for tolerance to a saline growth environment has been demonstrated in numerous grass species ranging from those found in coastal salt marshes (Hannon \& Bradshaw, 1968; Wu, 1981) to rocky, alpine environments (Acharya et al., 1992). Much of this variation is correlated with common human perceptions or measurements of the degree to which salt defines the local growth conditions (Ahmad et al., 1981; Wu, 1981). Large variation in tolerance arose between collection sites as close together as $10 \mathrm{~m}$, and this variation was highly correlated (correlation coefficient as high as 0.93 ) with soil salinity measured at the specific site of origin for all six grass species collected from within a single pasture (Venables \& Wilkins, 1978). The latter study included species with a range of inherent salt tolerances, from perennial ryegrass, which has low tolerance and rarely occurs naturally on saline soils, to alkaligrass, which could not have existed on the site prior to salinization (Venables \& Wilkins, 1978).

Dewey (1962) selected five standard crested wheatgrass populations for germination under salt stress at three different salt concentrations. Significant improvement in adult-plant forage yield under saline conditions was made over untreated checks for selection at one or two salt concentrations, with the exception of 'Summit' for which no progress was observed (Fig. 14-3). The lack of relationship between selection response and salt concentration during selection, and the general lack of progress led Dewey (1962) to conclude that a selection strategy for salt tolerance should be based on several stages in a plant's life cycle. These results also might suggest that heritability and additive genetic variation for salt tolerance in standard crested wheatgrass populations are extremely low.

In contrast, Ashraf et al. (1986a) selected seven species (creeping bentgrass, colonial bentgrass, Yorkshire fog, perennial ryegrass, red fescue, orchardgrass, and alkaligrass) for long seedling root growth in salt solution culture and ob- 


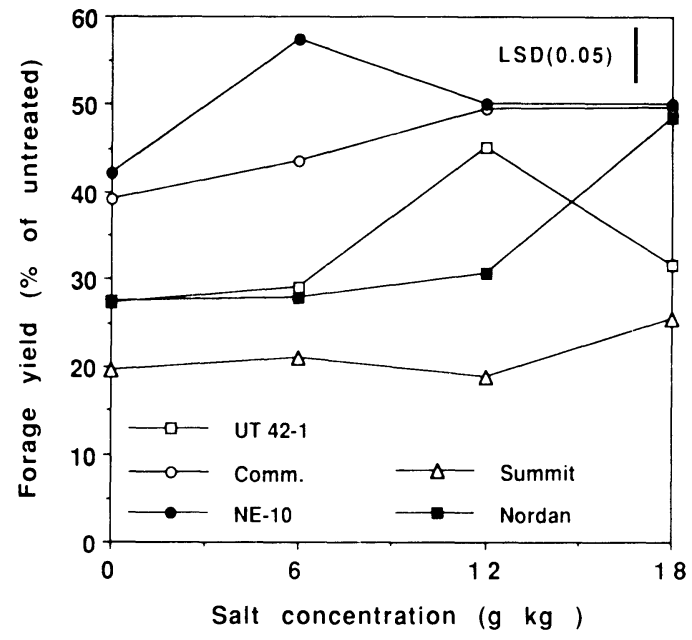

Fig. 14-3. Forage yield of crested wheatgrass progenies whose parents were selected for rapid germination at one of four salt concentrations. Forage yield of each population was measured at a constant salt application $\left(12 \mathrm{~g} \mathrm{~kg}^{-1}\right)$ and expressed as a percentage of forage yield for the respective population grown under no salt conditions (adapted from Dewey, 1962).

tained significant, consistent, and repeatable adult-plant responses in all seven species. Results were consistent with those of Venables and Wilkins (1978) in that large selection differentials were maintained for species with the entire range of inherent tolerance to salt. Ashraf et al. (1986b) produced polycross progenies of selected and unselected plants of four of the above species. Plant dry weight increased in the selected vs. unselected populations by 67 to $100 \%$, averaged over three salt concentration treatments. Selection also increased plant dry weight in a no-salt environment by 5 to $6 \%$ for perennial ryegrass, orchardgrass, and Yorkshire fog and by $80 \%$ for red fescue, suggesting that alleles for salt tolerance in these species did not carry a physiological cost. Selection also increased tiller number for all species at all salt concentrations, including zero, and decreased the shoot/root ratio in perennial ryegrass. Ashraf et al. (1986b) concluded that this selection protocol would have considerable agricultural impact if the results are as favorable through one or two more selection cycles. The success of these studies compared to that of Dewey's may be due to their greater selection intensities (0.0014-0.0094 for Ashraf et al., 1986a, vs. 0.025 for Dewey, 1962) and their reliance on a measurement of root growth in saline solution vs. speed of germination for the crested wheatgrass study.

\section{Heavy Metals}

Populations tolerant to at least one heavy metal element have been identified in at least 12 species and nine genera classified as cool-season grasses (Antonovics, 1975; Antonovics et al., 1971). Tolerance generally evolves in populations which are in close proximity to mine spoils or smelters and for which the soil has become heavily contaminated. Tolerance to $\mathrm{Zn}$ also can evolve from contamination by wind-blown mine waste or simply by $\mathrm{Zn}$ solubilization when 
rainwater comes in contact with electricity pylons (Coulaud \& McNeilly, 1992). Complete tolerance can evolve within 5 yr if selection pressures and genetic variability are great enough (Bradshaw, 1974; Wu et al., 1975). Evolution of specific metal tolerances is generally in response to the presence of that element in the soil (Antonovics et al., 1971). However, there are examples of cross tolerances to $\mathrm{Pb}$ and $\mathrm{Zn}$ in tufted hairgrass (Cox \& Hutchinson, 1980) and Ni in colonial bentgrass (Gregory \& Bradshaw, 1965) despite the absence of elevated levels of these elements in soils contaminated with other elements.

Tolerance to heavy metals in cool-season grasses has evolved through both avoidance (limited uptake) and true tolerance (exclusion from metal-sensitive sites, metal-resistant enzymes, or alteration of metabolism) mechanisms (reviewed by Ernst, 1976). Tolerance also may be environmentally sensitive, as illustrated by the breakdown of $\mathrm{Cd}$ tolerance in Yorkshire fog, tufted hairgrass, and red fescue when plants were transplanted from contaminated to uncontaminated soil (Baker et al., 1986). Cadmium tolerance lost in this way was not recovered when plants grown in uncontaminated soil were transplanted back into Cd-contaminated soil. Tolerance to heavy metals may carry a severe cost in both vegetative and reproductive fitness, although this generalization is by no means universal. Colonial bentgrass and sweet vernalgrass plants tolerant to $\mathrm{Pb}$ and $\mathrm{Zn}$ were extremely low in vegetative vigor and dry matter yield compared to nontolerant plants when grown in uncontaminated soil (Cook et al., 1972; Hickey \& McNeilly, 1975). Conversely, colonial bentgrass plants selected for varying degrees of $\mathrm{Cu}$ tolerance within three populations did not show a consistent association of inflorescence number or dry matter yield with $\mathrm{Cu}$ tolerance (Nicholls \& McNeilly, 1985).

Tolerance to heavy metals has been demonstrated to be heritable in several species (Bradshaw, 1976; Humphreys \& Bradshaw, 1977). Tolerance can be selected generally only in those species which are typically found to naturally colonize mine spoils or smelter grounds, although $\mathrm{Cu}$ tolerance in orchardgrass (Gartside \& McNeilly, 1974) and $\mathrm{Zn}$ tolerance in tall oatgrass (Humphreys \& Bradshaw, 1977) are exceptions to this. Because tolerance is so widespread in some species, Bradshaw (1974) concluded that tolerance alleles are present and maintained at very low frequency in populations of these species, increasing only when they confer a selective advantage. Fully tolerant plants may only exist in natural populations at a frequency of 1 to $2 \%$ (Walley et al., 1974). Furthermore, isozyme analysis of $\mathrm{Cu}$-tolerant creeping bentgrass populations show substantial polymorphism (Wu et al., 1975), suggesting that heavy metal selection pressures do not reduce genetic diversity, despite the high intensity of selection.

Macnair (1991) argued, on the basis of recent results and a selection response model, that only major genes for metal tolerance can explain the rapid and dramatic adaptive responses of these species to toxic soils. The consistent observation that fully tolerant individuals can be selected in a single generation suggests that a single major gene may be responsible for many of the observed metal tolerances. This also was suggested by one of the few conprehensive inheritance studies conducted on heavy metal tolerances, the case of arsenate tolerance in Yorkshire fog (Macnair et al., 1992). Conversely, the instability of $\mathrm{Cd}$ tolerance in some species (Baker et al., 1986) and the variable penetrance of 
arsenate tolerance in Yorkshire fog (Macnair et al., 1992) are suggestive of modifier genes, i.e., polygenic inheritance.

By the mid-1970s, three cultivars had been released for use in bioremediation of mine spoils-Merlin red fescue and Goginan colonial bentgrass with $\mathrm{Pb} / \mathrm{Zn}$ tolerance and Parys colonial bentgrass with $\mathrm{Cu}$ tolerance-all of which were increases of superior ecotypes (Humphreys \& Bradshaw, 1977). Relatively little effort has gone into development of screening techniques for methodically increasing heavy metal tolerance in a breeding program or investigating the inheritance of heavy metal tolerance. Gartside and McNeilly (1974), Symneonidis et al. (1985), and Walley et al. (1974) all screened populations otherwise unexposed to heavy metals, using either solution culture or artificially contaminated soil. A single screening identified fully Cu-tolerant (tolerance index $\geq 50 \%$ ) colonial bentgrass and orchardgrass plants occurring at a frequency of $0.8 \%$. In contrast, first-cycle survivors of four other species had tolerance indices ranging from only 7 to $20 \%$ (Gartside \& McNeilly, 1974). Parent-offspring heritability estimates were $\geq 0.66$ for each species. Walley et al. (1974) obtained fully $\mathrm{Cu}$ tolerant colonial bentgrass plants in a single screening. When the $\mathrm{Cu}$ survivors were screened for $\mathrm{Zn}$ tolerance, moderately $\mathrm{Zn}$-tolerant plants, which had retained their $\mathrm{Cu}$ tolerance, were identified.

Clearly, plant breeding efforts can aid in developing vegetative products for mine and smelter bioremediation. The extremely low frequency of metaltolerant plants in seven nontolerant colonial bentgrass populations, compared to high frequencies in cultivars Parys and Goginan (Symeonidis et al., 1985), suggest that plant breeding programs will require several cycles of intense selection to improve multiple metal tolerance in nontolerant populations. Two cycles of phenotypic selection with selection intensities of 0.003 to 0.004 increased $\mathrm{Zn}$ tolerance of four colonial bentgrass populations to approximately half the level acheived through 21 or $31 \mathrm{yr}$ of natural selection (Al-Hiyaly et al., 1993). Methodical selection for $\mathrm{Zn}$ tolerance in a fifth population was unsuccessful, mirroring the lack of evolved tolerance during the 31-yr exposure of this population to $\mathrm{Zn}$. Grass breeders with the objective of developing heavy metal tolerant germplasm would be wise to begin with germplasm already possessing some degree of tolerance to one or more metals.

\section{Seed Production}

As indicated earlier, seed production is one of the earliest selection criteria applied to forage grasses, both unconsciously and using methodical approaches. Yet it remains probably the most poorly documented of all selection criteria. It is one of the more contentious selection criteria, drawing wide opinions from grass breeders as to the attention to which it should be given compared to forage traits (Barker \& Kalton, 1989; Vogel et al., 1989). Kalton et al. (1996, see Chapter 13) discuss the problems and potentials associated with selection for improved seed production. Other authors (Sleper \& West, 1996; Vogel et al., 1996; Carlson et al., 1996; Jung et al., 1996; Berg et al., 1996; Wedin \& Huff, 1996; Asay \& Jensen, 1996a, b; Boe \& Delaney, 1996; see Chapters 15-24) discuss seed production practices and problems for individual species. We summarize the docu- 
mented progress in breeding cool-season forage grasses for improved seed production.

Lodge (1993) conducted three generations of pedigree selection to identify wild accessions of two wallaby grasses which might have potential for commercialization. High seed yield per inflorescence and compact inflorescence were the principal selection criteria. Both traits were markedly improved over the average wild accession, leading to a cultivar release for each species (Lodge \& Schipp, 1993). In orchardgrass, Falcinelli (1991) required only two generations of backcross selection to transfer seed retention from 'Marta' to 'Hallmark'. The Hallmark morphological phenotype was almost completely recovered, but with seed retention nearly equal to Marta, leading Falcinelli (1991) to conclude that seed shattering is controlled by a single partially or completely dominant gene. One cycle of selection for increased seed retention in perennial ryegrass had little effect on total seed production, but delayed seed shattering and increased 1000seed weight at maturity (Hides et al., 1993). Selection for earliness or seed yield per se had similar effects on a perennial ryegrass population, each approximately doubling seed yield per plant (Ceccarelli et al., 1981). Selection for increased 1000 -seed weight in this population was approximately half as effective at increasing seed yield as was selection for seed yield per se.

Knowles (1977) conducted five cycles of selection for increased seed yield, quality, and fertility in intermediate wheatgrass. Selection led to $89 \%$ higher seed yield, $8 \%$ higher volume weight of seed, $25 \%$ higher floret fertility index, and $65 \%$ less lodging. There appeared to be no detrimental effects of improved seed production, indeed forage yield also increased by $17 \%$. Lawrence and Ratzlaff (1988) selected for increased seed yield and quality along with foliage color in Altai wildrye. Combined selection for seed yield and blue foliage color approximately doubled seed yield during six cycles of mass selection. Increases in seed yield were considerably smaller when selected in conjunction with green or bluegreen foliage color. Two cycles of polycross selection for seed yield of smooth bromegrass led to a $40 \%$ increase in seed yield and a $15 \%$ increase in forage yield (Knowles et al., 1970).

Response to two cycles of selection for increased panicle seed yield varied among four orchardgrass germplasm sources, ranging from 4 to $18 \%$ per cycle for multilocation selection (convergent-divergent; Lonnquist et al., 1979) and 1 to $18 \%$ per cycle for single-location selection (Casler et al., 1993). The above selection protocols were carried out at four locations completely removed from normal orchardgrass seed production environments. When the original and selected populations were grown in Oregon, multilocation selection was superior to single-location selection, resulting in increased plot seed yield for two of the four germplasm sources, MO2 and WO11 (Barker et al., 1993). Apparently multilocation selection resulted in populations with greater genetic diversity than did single-location selection, giving them a greater buffering capacity and ability to produce high seed yields across a diverse range of sites. Seed yield of the MO2 and WO11 C2 populations also exceeded that of all eight check cultivars. Maturity was unconsciously shifted toward lateness in both of these populations (Barker et al., 1993), refuting the dogma present in the seed industry that lateness is always correlated with lower seed production. 


\section{Forage Nutritional Value}

Development of an in vitro procedure for rapid, repeatable, and relatively inexpensive evaluation of forage digestibility (Tilley \& Terry, 1963) is the single most important event in the evolution of cool-season forage grass selection criteria. Genetic variability exists for digestibility or related traits within nearly all economically important cool-season forage grass species (Hacker, 1982; Marten, 1989; Buxton \& Casler, 1993). Despite this knowledge, reports of actual genetic progress in breeding for improved forage digestibility of cool-season forage grasses are limited to orchardgrass (Breese \& Davies, 1970; Saiga, 1983; Rind \& Carlson, 1988), perennial ryegrass (Humphreys, 1989b), smooth bromegrass (Ehlke et al., 1986; Carpenter \& Casler, 1990), and timothy (Surprenant et al., 1990). Successful selection for crude protein concentration resulted in positive correlated selection responses for in vitro digestibility (Clements, 1969). Divergent phenotypic selection for neutral detergent fiber concentration, the single best laboratory predictor of intake potential (Van Soest, 1982), was successful in smooth bromegrass (Carpenter \& Casler, 1990) and reed canarygrass (Surprenant et al., 1988).

There are two principal reasons for this small number of studies reporting genetic improvements. First, while laboratory procedures are less expensive than actual animal evaluations, they are more expensive than most field-trait selection criteria. Limited funds or access to specialized laboratories prevents many breeders from using these selection criteria. Near-infrared reflectance spectrophotometry may be used to reduce the cost and time spent in the laboratory and increase the efficiency of selection in some cases (Reich \& Casler, 1985). Second, negative correlations between forage yield and nutritive value have been frequently reported and may serve as a deterrent to forage nutritional value breeding efforts (Van Bogaert, 1977). However, genetic improvements in forage digestibility do not necessarily lead to reduced forage yield (Casler \& Ehlke, 1986).

Eight experiments conducted on smooth bromegrass over a period of $20 \mathrm{yr}$ at numerous locations (Collins \& Drolsom, 1982; Casler et al., 1989; Carpenter \& Casler, 1990; and five other studies by Casler et al., 1989) suggested that $G \times$ $E$ interactions for forage nutritive value traits (involving locations, years, and harvest dates) are generally unimportant. Two cycles of phenotypic selection, using single-location testing, has led to a $2.8 \mathrm{~g} \mathrm{~kg}^{-1}$ increase in in vitro dry matter digestibility (IVDMD) of smooth bromegrass forage, when IVDMD was measured at different locations or in different years (Ehlke et al., 1986; Carpenter \& Casler, 1990). Genotype $\times$ year interactions appear to be important sources of variation in reed canarygrass (Hovin et al., 1976), tall fescue (Nguyen et al., 1982), and quackgrass (Greub et al., 1986). The relationship between genotype or population rankings in spaced plants and sward plots is relatively high in smooth bromegrass (Ugherughe et al., 1980; Ehlke et al., 1986; Carpenter \& Casler, 1990) and perennial ryegrass (Humphreys, 1989b). In these species, breeding for improved forage nutritive value with minimal or no replication of individual plants has been successful.

In species for which individual plants may have heading and anthesis dates up to $4 \mathrm{wk}$ apart, such as in orchardgrass, digestibility is negatively correlated 
with earliness when plants are harvested on an individual date (Frandsen, 1986). Conversely, digestibility is positively correlated with earliness when plants are harvested according to a specific stage of maturity (Christie \& Mowat, 1968; Davies, 1976). In either case, genetic changes due to selection for high digestibility would likely be due to accumulation of alleles for early or late maturity, rather than digestibility per se. Research on perennial ryegrass has shown an early maturing cultivar to have higher forage nutritive value than a late-maturing cultivar under a high stocking rate of dairy cows, but the effect was reversed under a low stocking rate (Gately, 1984). Thus, genetic changes in maturity can be used to more efficiently exploit a range of pasture management systems. Some authors have suggested using covariance analysis to adjust family or plant means to a constant level of maturity prior to selection, in cases where selection is based on replicated units (Frandsen, 1986; Buxton et al., 1987; van Santen \& Casler, 1990).

Humphreys (1989c) has shown the early maturing perennial ryegrass cultivar, Aurora, to be a source of high WSC concentration and in vitro digestibility. In segregating progeny of crosses between Aurora and late-maturing cultivars, WSC concentration could be increased independent of changes in maturity (Humphreys, 1989b). Water soluble carbohydrate concentration also appears to be positively related to in vitro digestibility in tall fescue (J.A. Balasko, 1991, unpublished data). High- and low-WSC tall fescue clones (183 vs. $23 \mathrm{~g}$ WSC $\mathrm{kg}^{-1}$ dry matter) differed by at least $59 \mathrm{~g} \mathrm{~kg}^{-1}$ in IVDMD for all fermentation times between 3 and $48 \mathrm{~h}$.

There is very little data to suggest what effect selection for increased IVDMD or other measures of forage nutritive value may have on adaptive traits such as pest or stress resistance. Buxton and Casler (1993) reviewed this subject and suggested that: (i) long-term unconscious selection has led to decreased nutritive value of forage crops due to emphasis on yield and vigor traits, and (ii) increased forage nutritive value, if accomplished by reducing the concentration of cell wall constituents such as lignin or phenolics, may lead to reduced pest resistance. On the other hand, selection for reduced leaf cellulose concentration or tensile strength, both associated with increased IVDMD, led to increased tolerance to freezing and drought (Lancashire et al., 1977; Silcock \& Wilson, 1982; Wilson, 1981). Silcock and Wilson (1982) speculated that greater cell wall flexibility may be partially responsible for both increased drought and freezing tolerance.

The relative ease with which digestibility of some forage crops can be increased by selection suggests that a considerable amount of additive genetic variation controls this trait. Genetic studies support this conclusion in a population of tall fescue (Nguyen et al., 1982), a population of reed canarygrass (Hovin et al., 1976), and three populations of smooth bromegrass (Ross et al., 1970; Sleper et al., 1973; Ehlke et al., 1986). There also is strong evidence for nonadditive gene action controlling traits related to digestibility in populations of smooth bromegrass (Tan et al., 1978), reed canarygrass (Marum et al., 1979), and perennial ryegrass (Hayward \& Abdullah, 1985; Humphreys, 1989b).

The ultimate test of a breeding program with improved forage nutritive value as its goal is in animal performance of the selected populations. A litera- 
ture review identified only three references to animal performance trials addressing this subject in cool-season forage grasses, the small number presumably due to their greater expense. Progenies of two smooth bromegrass synthetics selected for divergent IVDMD differed by $65 \mathrm{~g} \mathrm{~kg}^{-1}$ in IVDMD averaged over $2 \mathrm{yr}$ (Kamstra et al., 1973). Hay produced on four 0.135 -ha plots planted to each synthetic was fed to wether lambs over a 47-d period. Animal weight gains were $32 \%$ greater for the high-IVDMD synthetic, than for the low-IVDMD synthetic (62 vs. $47 \mathrm{~g} \mathrm{~d}^{-1}, 2.9$ vs. $2.2 \mathrm{~kg}$ over $47 \mathrm{~d}$ ). 'Badger' smooth bromegrass was selected for increased IVDMD and had $20 \mathrm{~g} \mathrm{~kg}^{-1}$ higher IVDMD than 'Rebound', the second highest cultivar for IVDMD averaged over six location-years in Wisconsin and Iowa field trials (Casler \& Drolsom, 1992, and unpublished data). In a set-stocking grazing trial, Badger averaged $11 \%$ higher sheep weight gains than Rebound ( 0.21 vs. $0.19 \mathrm{~kg} \mathrm{~d}^{-1}, 25$ vs. $23 \mathrm{~kg}$ over the 117 -d grazing season). Stocking rates were 45 animals per hectare from 15 May through 3 June and 29 animals per hectare from 12 June through 24 September and forage availability was equal for the two cultivars (Casler \& Drolsom, 1992, and unpublished data). 'Manska' intermediate wheatgrass (Mandan I 2781) was selected for increased IVDMD and had 11 and $25 \%$ higher average daily gain than two standard cultivars (Moore et al., 1990).

Munro and Walters (1986) summarized three ryegrass feeding trials in which cultivars differed by 12 to $30 \mathrm{~g} \mathrm{~kg}^{-1}$ in digestibility on offer. In each case, animal performance (dry matter intake and/or weight gains) was higher for the highdigestibility cultivar, ranging from a 4 to $35 \%$ increase. Although these studies are limited in both scope and duration they provide the only documentation that plant breeding efforts can improve animal performance from cool-season forage grasses. There are other documentations of this phenomenon in warm-season grasses (Anderson et al., 1988; Burton \& Monson, 1988; Shoop et al., 1976).

Animal evaluation of forage nutritive value are too expensive to use in early stages of breeding programs, but may be useful in discriminating among genotypes or families differing in palatability. The strong correlations between palatability and indole alkaloid concentration in reed canarygrass (Simons \& Marten, 1971) suggest that either animal preference or a laboratory analysis would be an appropriate selection criterion for low alkaloid concentration. There also is some evidence that the most palatable lines derived from ryegrass $\times$ fescue hybrids also are highest in water concentration and in vitro digestibility (Berg et al., 1979; Buckner et al., 1979).

Orchardgrass synthetics that produced relatively few reproductive tillers were developed with the idea that reduced stem development would enhance forage nutritive value of the crop (Berg et al., 1981). Panicle production was reduced by up to $80 \%$ in the northwest USA and $58 \%$ in Washington (Table 14-4). Large genetic variances within the Syn B and Syn C suggest they have potential to provide genotypes with good Washington seed production, but low panicle production in the northeast USA and similar environments (Hovin et al., 1966). Although forage yield of Syn B and Syn C was not reduced by suppressed panicle production, results are conflicting on laboratory measures of forage nutritive value (Berg et al., 1981; Sullivan et al., 1962). Berg et al. (1981) suggested the need to evaluate sparse-flowering orchardgrass synthetics for animal 
Table 14-4. Panicle numbers and seed yields of orchardgrass synthetics differing in reproductive stem frequency.

\begin{tabular}{|c|c|c|c|c|}
\hline \multirow[b]{2}{*}{ Synthetic } & \multicolumn{3}{|c|}{ Panicle number } & \multirow{2}{*}{$\begin{array}{c}\text { Seed yield } \\
\text { Washington }\end{array}$} \\
\hline & Vermont $\uparrow$ & Pennsylvania $†$ & Washington $\ddagger$ & \\
\hline & 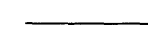 & $-2 \longrightarrow$ & plant $^{-1}$ & g plant ${ }^{-1}$ \\
\hline A & 131 & 170 & 116 & 50 \\
\hline B & 76 & 85 & 49 & 21 \\
\hline C & 46 & 35 & 63 & 32 \\
\hline
\end{tabular}

$\dagger$ Adapted from Berg et al. (1981).

$\ddagger$ Adapted from Hovin et al. (1966).

performance potential. These populations may be potential germplasm for orchardgrass pastures, reducing wasted dry matter that often results from excess stem production when stocking rates are too low during spring growth.

\section{Conclusions}

Numerous selection criteria have been used in the development of improved cool-season forage grass germplasm. Additive genetic variability exists for traits that allow development of distinct pasture or hay-type grasses and of mixtures with perennial legumes. Although cool-season forage grasses suffer from parasitism of numerous disease organisms, sources of resistance exist to most of these organisms. Breeding for increased forage yield is a slow and expensive process. There is little documentation of improvements by selecting for forage yield per se. Changes in certain morphological or physiological traits may lead to increased forage yield, but usually induce serious genotype $\times$ harvest management interactions. There is a wealth of genetic variability controlling tolerance to various abiotic stresses, much of which can be readily identified by study of edaphic factors and human disturbances. Some of this variation has been useful in bioremediation of disturbed sites. Recent laboratory technologies have allowed large and rapid improvements in forage nutritional value without sacrifices in forage yield, and there is strong evidence that these efforts can improve animal performance.

\section{BREEDING PROCEDURES}

Breeding procedures used in cool-season forage grass improvement are generally not unique to this group of plants. They are usually adaptations of procedures commonly used in cereal and other crop species. Selection of a procedure to accomplish a breeding objective is usually based on knowledge of the species being modified, and the amount and type of genetic variation that can be assessed by the breeder. Fiscal, physical, and time constraints imposed on the breeder also influence choice of breeding procedures.

Most cool-season forage grasses are outcrossing, polyploid, perennial, and can be propagated vegetatively (Hanson \& Carnahan, 1956; Hovin, 1980; Sleper, 1987). Due to their outcrossing nature, they exist in the wild as random or pseu- 
dorandom mating populations, and improved cultivars are usually maintained and marketed as random mating populations (Hayward, 1988). Because they are perennial, individual plants of most species can be maintained for several years, eliminating the need for selfing or inbred line development in some breeding procedures. The ability of the breeder to vegetatively propagate most cool-season forage grasses also eliminates the need for inbred development in some procedures and provides unique opportunities for modification and adaptation of breeding procedures to these species. Although many cool-season forage grasses are polyploid, they often behave as diploids and in practice are normally handled as such (Hanson \& Carnahan, 1956).

Because forage grasses have been cultivated and subjected to unconscious and methodical selection for a relatively short time, and because they generally have a wide geographic range (see Chapters 15-24), considerable genetic variation is present in most species. Furthermore, due to the heterogeneous nature of the populations, the heterozygous state of individuals, and the reliance on asexual propagation in the wild (tillering, rhizomes, etc.) additive gene action generally predominates (Breese \& Hayward, 1972). Considerable genetic variation has been collected for some species and is preserved in numerous national and international collections where it is readily available to breeders (Williams, 1984; Tyler et al., 1987; Natl. Res. Council, 1991). Maintaining genetic variation in working populations, as well as avoiding inbreeding depression, which is severe in most cool-season forages (Hanson \& Carnahan, 1956), is a concern in most breeding programs. Generally, effective population size is kept at 50 individuals or more (Vogel et al., 1989).

Breeding procedures used for cool-season forages range from primitive ecotype collection to genetic manipulation at the molecular level. Ecotype collection produced many of the cool-season forage grasses in widespread use today. Examples include 'Kentucky 31' tall fescue (Fergus \& Buckner, 1972), 'Clair' timothy (Buckner, 1962), 'Lincoln' smooth bromegrass (Hein, 1955), and 'Marshall' Italian ryegrass (Arnold et al., 1981). 'Grasslands Matua' rescuegrass was developed by increasing selected plants from a single high-performing accession, selected from among many accessions evaluated in New Zealand (Rumball, 1974). It has demonstrated potential utility as a forage crop in Oregon (Ballerstedt et al., 1990) and Pennsylvania (Jung \& Shaffer, 1990). In addition to ecotypes and accessions from plant collections, existing cultivars serve as source material in most cool-season grass breeding programs. In more mature cool-season grass breeding programs, elite plants may be kept for many years in a source nursery for later use in developing populations with particular traits (Sleper, 1987).

\section{Recurrent Selection}

Recurrent selection is a cyclical population improvement method for increasing the frequency of favorable alleles and superior genotypes (Hallauer \& Miranda, 1981). Mass selection and phenotypic selection are by far the most common recurrent selection methods employed in cool-season forage grass breeding. Mass selection is described by Poehlman (1983) as "a selection procedure in which individual plants with desirable traits are chosen, and the seed harvested 
from them is bulked to grow the following generation." It is usually based on phenotypic selection, and pollination is not controlled. Thus, effective population size is maintained at some level exceeding the number of selected individuals with this procedure (Falconer, 1989). This method is used widely in coolseason forage grass breeding and has produced cultivars such as AU Triumph tall fescue (Pedersen et al., 1983). It also is used by most breeders and foundation seed programs to keep cultivars true-to-type by eliminating off-types.

Phenotypic selection differs from mass selection in that some attempt is generally made to limit pollination to only those individuals selected to represent the next generation. This is facilitated in situ, by removing inflorescences from nonselected individuals prior to anthesis (Reich \& Casler, 1985) or ex situ, by taking vegetative propagules from each selected individual. Vegetative propagules may be transplanted into polycross blocks or may be placed in water or nutrient solution prior to anthesis. The latter approach is one of the main restrictions in the Recurrent Restricted Phenotypic Selection (RRPS) system designed by Burton (1974). Its other restrictions were the use of grid selection to help control environmental variation (Gardner, 1961) and the use of self-incompatible germplasm to reduce the incidence of selfing. Adaptations of the RRPS system have been applied to numerous species and selection criteria.

Marshall and Slinkard (1972) compared one cycle each of mass selection and phenotypic selection for increasing seed set and seed weight of Russian wildrye. Phenotypic selection resulted in greater gains than mass selection: $8 \%$ higher for seed set, $2 \%$ higher for seed weight, and $18 \%$ higher for seed yield per plant. However, phenotypic required an additional year for each cycle (3 vs. 2 yr), more than negating its advantage in pollen control in this study. Vogel and Pedersen (1993) predict that the theoretical superiority of phenotypic selection, in particular RRPS, over mass selection should make the latter obsolete. However, in view of Marshall and Slinkard's (1972) results, and the gains made by many breeders using mass selection (reviewed under "Selection Criteria"), it seems that mass selection will continue to hold a place in cool-season forage grass breeding programs, depending on the selection criteria and objectives of the breeder.

Because perennial plants can be maintained for several years, individuals also can be selected on the basis of their progeny performance (genotypic selection) and directly intermated following progeny evaluation. Both genetic and cultural factors influence the breeder's decision to use phenotypic or genotypic selection. Generally, phenotypic selection is used for highly heritable traits and genotypic selection is used for less heritable traits (Hallauer \& Miranda, 1981). Progeny testing of individual families or lines is common in genetic studies of cool-season forage grasses and is used in nearly all private breeding programs, but is relatively uncommon in published recurrent selection programs.

Vogel and Pedersen (1993) describe three systems for conducting progeny test selection in forage grasses: half-sib progeny test (HSPT), between and within family selection (B\&WFS), and recurrent multistep family selection (RMFS). The latter differs from B\&WFS only in that two populations are produced from each cycle, one representing all selected genotypes and used to advance to the next cycle, and the second representing a superior subset of genotypes for testing as a potential cultivar. They argue that HSPT is the least efficient of all breeding 
systems for forage grasses, and that, in most prior applications, failure to make genetic progress was due to linkage and/or Hardy-Weinberg disequilibrium, resulting in family variation due, in part, to nonadditive genetic effects. Similarly, Breese and Hayward (1972) argued that progeny test selection may squander additive genes, making dominance and epistasis more important in selected progenies compared to their parents. Generally, genotypic selection programs require a longer cycle time than phenotypic selection.

One cycle of HSPT selection ( $7 \mathrm{yr}$ ) was as effective as a combination of one cycle of mass selection plus one cycle of phenotypic selection (a total of 6 yr) for increasing seed yield of intermediate wheatgrass (Knowles, 1977). All selections were made in the $2 \mathrm{nd}$ or $3 \mathrm{rd}$ yr after establishment and Knowles warned that this delay is necessary to obtain accurate estimates of plant or family performance. Nevertheless, HSPT cycle time could be reduced to $5 \mathrm{yr}$, if selections are intercrossed during the winter following the 3rd yr of evaluation, as Knowles (1977) did in the phenotypic selection protocol, and if greenhouse seed production is adequate for progeny testing. After one cycle of selection for higher forage yield in perennial ryegrass, phenotypic selection led to a 9 and $54 \%$ higher yield than HSPT, while B\&WFS led to 4 and $25 \%$ higher yield than HSPT, for two evaluation experiments (Van Dijk, 1979).

\section{Synthetic Cultivars}

A synthetic cultivar is defined as "the advanced generations of open-pollinated seed mixtures of a group of strains, clones, or inbreds, or of hybrids among them" (Poehlman, 1983). According to Allard (1960), "the key point of distinction between synthetic cultivars and cultivars developed by mass selection... lies in the way the constituent genotypes are chosen." Genotypes are selected primarily for high general combining ability (the ability to pass on favorable alleles to their progeny when mated to other genotypes). They are then intermated in all possible combinations and maintained as random mating populations in succeeding generations. Heterosis or hybrid vigor is theoretically captured with the loss of only $l / n$ of the heterosis in the $\operatorname{Syn}_{2}$ generation where $n=$ the number of parents in the synthetic cultivar. According to the Hardy-Weinberg rule, if generations are advanced by random mating, there should be no further loss of heterosis (Allard, 1960). In practice, inbreeding depression and/or genetic instability can contribute to a decrease in performance in advanced generations (Hayward \& Abdullah, 1985).

The above description of synthetics is accurate for crops in which significant sources of heterosis can be identified. However, cultivars described as synthetic also are produced in cool-season forage grasses where predominantly additive genetic variance is expected. Breese and Hayward (1972) define synthetic cultivars as populations "produced by hybridizing in all possible combinations a number of selected genotypes, and thereafter maintained by random mating in isolation (over a limited number of generations). The stated aims are to increase the frequency of genes with favorable expression in particular characters while avoiding inbreeding depression." In practice, such synthetic cultivars are usually developed from a small number of parents (8-12) while a cultivar developed 
using mass selection may be based on an effective population size of $>100$ individuals.

\section{Interspecific and Intergeneric Hybridization}

Hybridization between plant species has occurred in nature, especially among the grasses, as an important mechanism of plant evolution. With the discovery of the colchicine technique in 1937 for inducing polyploidy (amphiploids) in hybrids, plant breeders have attempted to use amphiploids to break down perceived yield barriers by creating more variability within a species (Dewey, 1980).

In many cases, hybrids between species are male and female sterile. In nature, polyploids are most likely the result of an unreduced $(2 n)$ gamete. For example, a $2 n$ egg from one species is fertilized by haploid ( $n$ ) pollen from another species resulting in a triploid hybrid. If this triploid hybrid produces a $2 n$ egg which is fertilized by $2 n$ pollen from the same plant, the resulting plant is an allopolyploid (Harlan \& deWet, 1975). Production of these $2 n$ gametes often results from failure of the first or second meiotic division. Successful hybridizations that occur in nature usually result from crosses between races, ecotypes or cytotypes. Wide crosses that are successful, usually require in vitro culture procedures and/or colchicine-doubling. It was demonstrated by van Santen et al. (1991) that $2 n$ eggs and $2 n$ pollen were formed in orchardgrass, based on the recovery of tetraploid progeny from $2 x-4 x$ and $4 x$ - $2 x$ crosses. Also, cytological analyses of diploid crested wheatgrass indicated that $2 n$ pollen was produced via restitution of the second meiotic division (Ray \& Tokach, 1992).

The most prevalent method of obtaining fertility in interspecific and intergeneric hybrids of cool-season grasses is colchicine doubling to inhibit spindle fiber formation. The lack of spindle fiber formation prevents division from occurring, resulting in a cell with a doubled number of chromosomes (Singh, 1993). Variation can result from colchicine treatment as demonstrated in perennial ryegrass (Hague \& Jones, 1987; Francis \& Jones, 1989).

Breeding efforts that have concentrated on improving cool-season grasses and understanding their phylogeny through hybridization and colchicine doubling have focused on the ryegrass-fescue complex (Lewis, 1983; Thomas \& Humphreys, 1991; Van Bogaert, 1975), and members of the Triticeae tribe (Asay, 1992). The tall fescue cultivars Kenhy (Buckner et al., 1977) and Johnstone (Buckner et al., 1983) were derived from hybrids between Italian ryegrass and tall fescue (Fig. 14-4); the crested wheatgrass cultivar Hycrest (Asay et al., 1985) was derived from hybrids between the induced tetraploid, fairway crested wheatgrass, and the natural tetraploid, standard crested wheatgrass; and the wheatgrass cultivar NewHy (Asay et al., 1991) was derived from hybrids between quackgrass and bluebunch wheatgrass.

In perennial ryegrass, a stable cytoplasmic male sterile type is available as a result of crossing an $\mathrm{F}_{4}$ hybrid of perennial ryegrass $\times$ Italian ryegrass with meadow fescue (Wit, 1974). This line has been used in a breeding program aimed at the production of $F_{1}$-hybrid seed (Creemers-Molenaar et al., 1992). Similarly, 
GERMPLASM \& CULTIVAR DEVELOPMENT

447

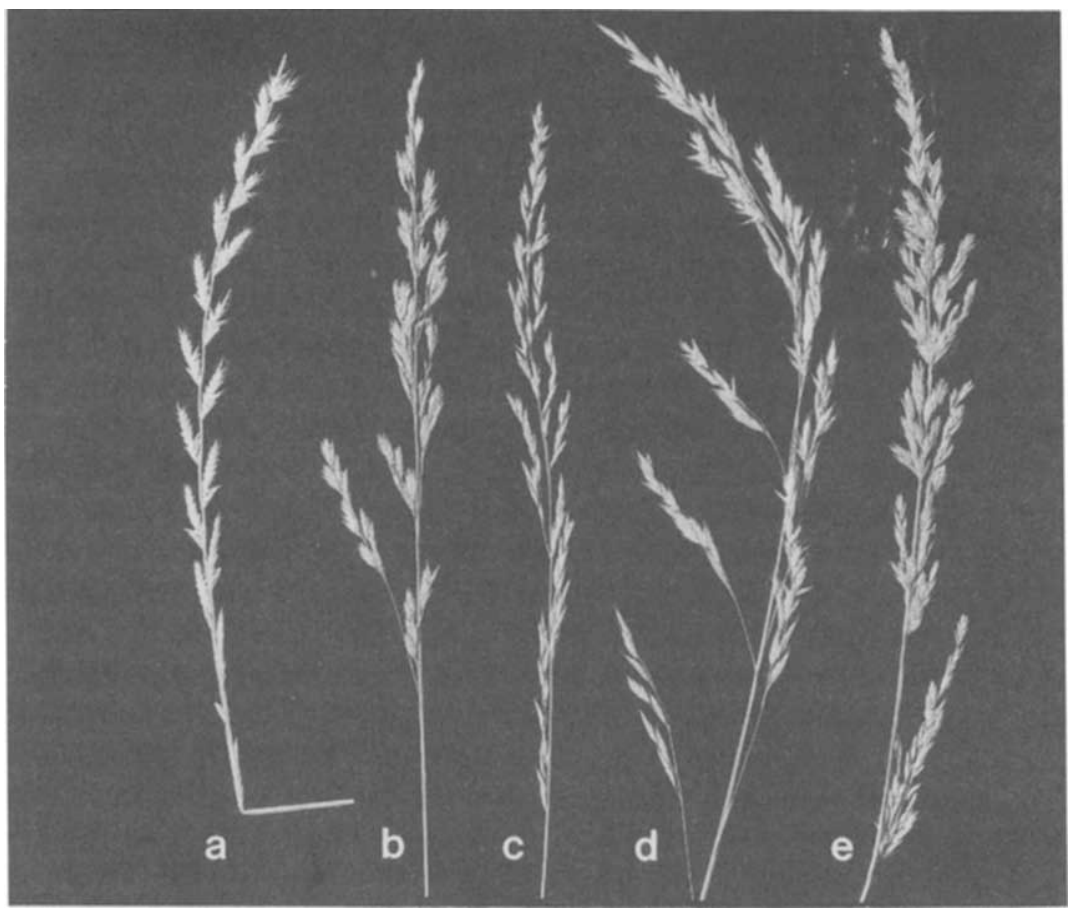

Fig. 14-4. Inflorescence from: $a$ ) Italian ryegrass, $b$ ) tall fescue, $c$ ) Italian ryegrass $\times$ tall fescue hybrid, $d$ ) colchicine-doubled Italian ryegrass $\times$ tall fescue amphiploid and $e$ ) one of the Kenny tall fescue clones derived from the amphiploid.

the orchardgrass cultivar Hawk was developed by hybridization using a cetoplasmic male sterile line.

Conclusions

Few breeding procedures applied to cool-season forage grasses are unique to this group of species. Because the history of domestication and breeding offorts on annual grain crops are much older and broader than perennial forage crops, most new procedures derive from research on annual grain crops. Nevertheless, forage breeders have used novel characteristics of cool-season forage grasses (perenniality, multiple inflorescences, and vegetative propagation) to cheate more efficient and effective modifications of existing procedures. These procedures are extremely effective at increasing the frequency of favorable alleles and superior genotypes in populations. The greatest weakness of current coolseason forage grass breeding procedures is the low amount of nonaddictive gemetic variation utilized in selection programs. Development of effective and economical mechanisms for: (i) hybrid seed production, (ii) large-scale vegetative propagation or micropropagation of superior clones, or (iii) somatic embryogenisis as a means of synthetic seed propagation (Gray \& Purohit, 1991) may revolutionize cool-season forage grass breeding in the same way that hybrids revolutionized maize and bermudagrass breeding. 


\section{IN VITRO AND MOLECULAR TECHNOLOGIES}

When interspecific crosses have been used to create new genetic variability, it often has been necessary to perform embryo rescue and to double the chromosome complement of the interspecific hybrid with colchicine to obtain plants that have reproductive fertility. More recently, inflorescence culture and protoplast fusion have expanded the possibilities for wide hybridization. Additional means of expanding variation are available through tissue culture (somaclonal variation), anther culture, and plant transformation. Selection can be facilitated by use of isozyme and/or DNA markers. In situ hybridization can be used either to: (i) determine genome donors in hybrid derivatives or (ii) locate DNA markers to a particular chromosome.

\section{Tissue Culture}

The tissue culture techniques discussed in this section have been used successfully with one or more cool-season grasses. These techniques include embryo rescue, meristem tip culture, inflorescence culture, and anther culture. The objective of this research is to: (i) expand the capabilities of the plant breeder, (ii) create new variablity, and/or (iii) make breeding more efficient.

Embryo rescue, the most utilized technique, is used when an incompatible relationship exists between the hybrid embryo and endosperm, or seed viability is questionable. Successful hybridizations of cool-season grasses that utilized embryo rescue include tall fescue $\times$ Italian ryegrass (Eizenga \& Buckner, 1986); tall fescue $\times$ orchardgrass (Matzk, 1981), Canada wildrye $\times$ rye (Park \& Walton, 1989a), Pseudoroegneria cognata (Hackel) A. Löve $\times$ Psathyrostachys huashanica Keng, $P$. cognata $\times$ beardless wheatgrass (Wang, 1978), and barley $\times$ slender wheatgrass (Aung, 1991).

Meristem tip culture can be used either to vegetatively propagate or eliminate viruses from cool-season forage grasses. Dale (1977a) successfully regenerated timothy, orchardgrass, meadow fescue, red fescue, tall fescue, Italian ryegrass and perennial ryegrass using meristem tip culture. He also demonstrated with Italian ryegrass that (i) the meristem tips could be stored in vitro using cold storage for a period of $3 \mathrm{yr}$ (Dale, 1980) and (ii) ryegrass mosaic virus could be eliminated (Dale, 1977b).

In inflorescence culture, the immature inflorescence is removed and plated on a medium containing auxin, to encourage regeneration of plantlets. Cool-season grass species from which plantlets have been regenerated via inflorescence culture include tall fescue (Dale \& Dalton, 1983; Eizenga \& Dahleen, 1990); Italian and perennial ryegrasses (Creemers-Molenaar et al., 1988); meadow fescue, timothy, and orchardgrass (Conger \& McDonnell, 1983; Dale \& Dalton, 1983); Canada wildrye (Park \& Walton, 1989b); and Kentucky bluegrass (van der Valk et al., 1988).

Inflorescences of hybrids have been cultured in an attempt to obtain amphiploids. Inflorescences of Italian ryegrass $\times$ tall fescue (Kasperbauer et al., 1979; Rybczynski et al., 1983); Wimmera ryegrass $\times$ tall fescue (Rybczynski et 
al., 1983); and slender wheatgrass $\times$ Canada wildrye (Kumar \& Walton, 1992) hybrids have been successfully cultured for this reason.

Another reason for attempting to obtain regeneration from inflorescence culture is to obtain haploid plants. Haploids are useful, first, to unmask undesirable recessive genes and enable the forage grass breeder to make selections more quickly. Second, inbred lines may be obtained more quickly by chromosome doubling of the haploid plants. Third, haploids can be used to more accurately determine the genome constitution of the polyploid species. Kasperbauer (1990a) was successful using inflorescence culture to obtain haploid tall fescue plants which he suggested developed from anthers. No other haploids of tall fescue have been reported to date. Based on mitotic analyses, the tall fescue haploids were doubled using inflorescence culture (Kasperbauer, 1990b).

Haploid plants have been obtained for some of the cool-season grasses by culturing individual anthers (Fig. 14-5). These plantlets most likely were regenerated from pollen cells. Reports of haploid or aneuhaploid regenerants include perennial ryegrass (Olesen et al., 1988; Boppenmeier et al., 1989), Italian ryegrass (Boppenmeier et al., 1990), tall wheatgrass (Wang et al., 1991; Niu et al., 1991), intermediate wheatgrass, and crested wheatgrass (Niu et al., 1991). Recently, six anther culture-deprived haploids of perennial ryegrass were spontaneously chromosome-doubled (Madsen et al., 1993). Some of the selfed offspring showed a significant increase in self-fertility.

Use of haploids to determine the genome constitution of the polyploid grass species was demonstrated with tall fescue by Eizenga and Kasperbauer (1985). The low pairing between the three genomes indicated tall fescue has three distinct genomes and is an allohexaploid species.

Somaclonal variation (Larkin \& Scowcroft, 1981) describes the genetic and chromosomal changes that occur as a result of tissue culture. Reports of somaclonal variation in cool-season species include changes in chromosome number and structure in regenerants from Italian ryegrass (Ahloowalia, 1976), perennial ryegrass (Ahloowalia, 1976), tall fescue (Reed \& Conger, 1985; Eizenga, 1989; Dahleen $\&$ Eizenga, 1990) and Italian ryegrass $\times$ tall fescue hybrids (Humphreys \& Dalton, 1992). Skipp and White (1988) showed a range of resistance to crown rust in perennial ryegrass regenerants from inflorescence culture. Additionally, isozyme variation was reported in tall fescue regenerants (Dahleen \& Eizenga, 1990; Eizenga \& Cornelius, 1991) and Italian ryegrass $\times$ tall fescue regenerants (Humphreys \& Dalton, 1992).

\section{Protoplast Fusion and Transformation}

Somatic cell fusion involves hybridizing protoplasts of two different species and obtaining plantlets from the fused protoplasts. It is the least developed method for obtaining hybrids, but has the potential to broaden the range of species that can be hybridized. Protoplasts have been obtained from tall fescue (Dalton, 1988a, b; Takamizo et al., 1990), perennial ryegrass (Dalton, 1988a,b; Creemers-Molenaar et al., 1989), Italian ryegrass (Dalton, 1988a), orchardgrass (Horn et al., 1988a), Kentucky bluegrass (van der Valk et al., 1988), redtop (Asano \& Sugiura, 1990), and meadow fescue (Wang et al., 1993). Basal leaf tissue, 

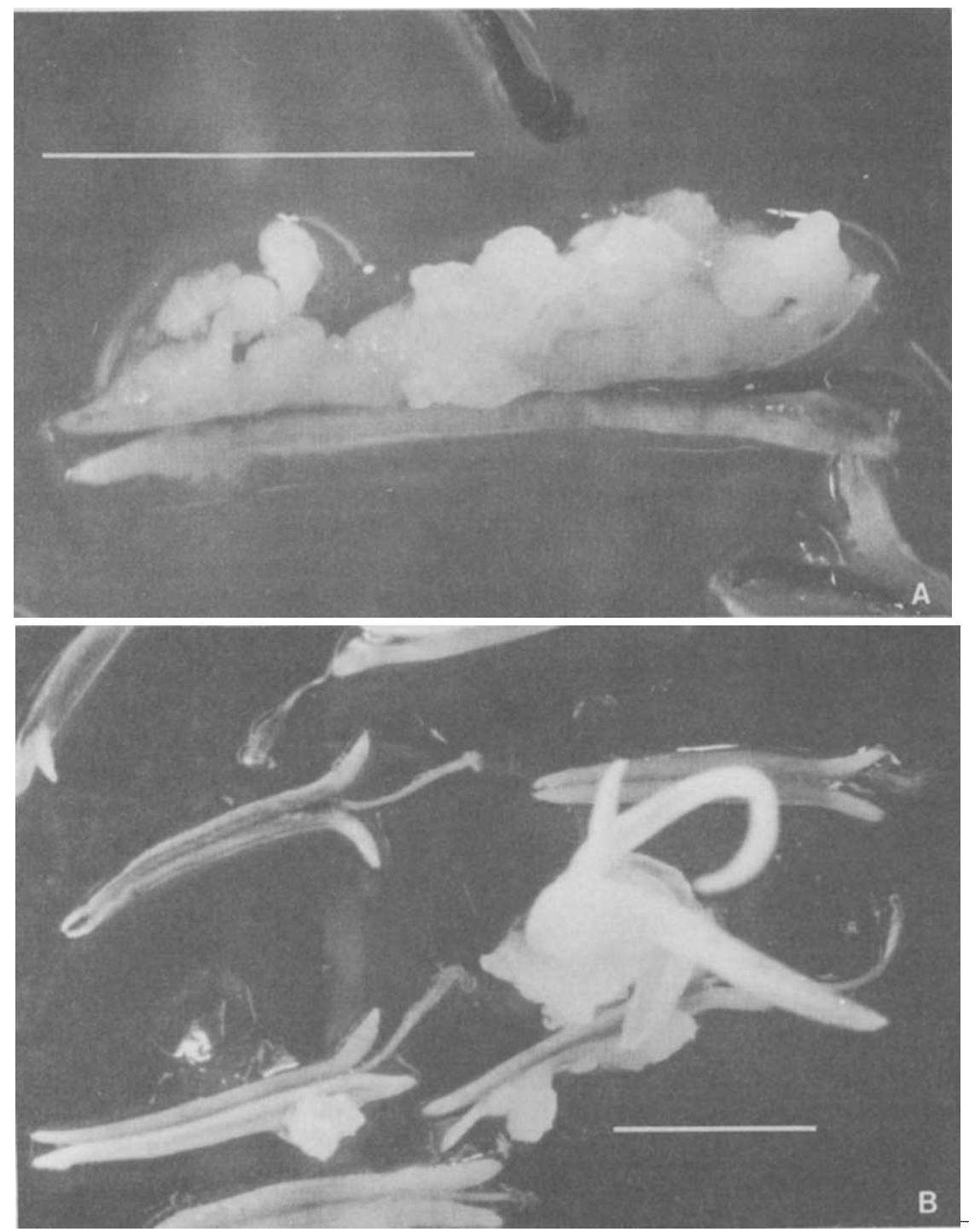

Fig. 14-5- Development of tall wheatgrass anther culture tissue: $a$ ) anther locule filled with embryoids and calli, and $b$ ) direct regeneration of a plantlet from an anther (reprinted from Marburger \& Wang, 1988).

immature inflorescences, immature embryos and seed have been used as explants for obtaining callus, which is used to develop suspension cultures from which protoplasts are obtained. Green and/or albino plantlets of the aforementioned species have been regenerated from protoplasts, but only the meadow fescue plants were reported to be fertile. Also, green plants have been obtained from somatic hybrids of tall fescue $\times$ Italian ryegrass (Takamizo et al., 1991). 
Reports of genetic transformation involve the incorporation of desirable gene(s) into a plant host often utilizing a vector such as a plasmid, particle gun, electroporation, or microinjection. The first successful transformation of a coolseason forage grass was incorporation of the single gene trait, hygromycin resistance, into orchardgrass (Horn et al., 1988b; Conger, 1991). Orchardgrass protoplasts were isolated from embryogenic suspension cultures, hygromycin resistance was incorporated by direct uptake of a DNA plasmid containing the gene, and whole plants were regenerated from the protoplasts. Unfortunately, these plants were low in vigor, could not be induced by flower, and eventually died. More recently, the same hygromycin resistance gene and a phosphinothricin acetyltransferase gene were introduced into tall fescue (Wang et al., 1992) using procedures similar to those reported for orchardgrass. Integration of these genes into the tall fescue genome was verified by Southern blot hybridization and in situ hybridization. Expression of the genes was confirmed by an enzyme assay for hygromycin or treatment with phosphinothricin. Fertility of the transgenic plants and transmission of the introduced genes is being determined. Using electroporation, Ha et al. (1992) incorporated the hygromycin resistance gene into tall fescue. These successes indicate that it should be possible to incorporate single gene traits such as pest and herbicide resistance into cool-season grass species.

The transfer of multigenic traits will be more difficult because of the number of genes that would need to be transferred. Work that is being done with DNA markers will make it possible to identify the location of traits that are multigenic. This should make it possible to transform or move multigenic traits. In the cool-season forage grasses, the multigenic traits of most interest would probably be forage quality or adaptation to a broader range of environments (Hanna \& Hill, 1985).

\section{Genetic Markers}

In most cool-season forage species there are very few genetic markers but, in the past $20 \mathrm{yr}$, work has progressed toward development of isozyme markers. More recently, the development of DNA-based markers which utilize the technology that is used to reveal DNA-based polymorphisms appears to be even more useful.

In some cases, plant breeding is enhanced by the use of isozyme markers that can be used to identify desirable traits if there is linkage between a specific trait and an isozyme marker. This was illustrated in perennial ryegrass where there was linkage between the PGI-2 (phosphoglucoisomerase) isozyme and the S locus for self-incompatibility (Cornish et al., 1980). Hayward (1992) evaluated the effect of isozyme selection on forage yield and flowering time in perennial ryegrass. His work suggested a possible linkage of quantitative trait loci for water soluble carbohydrates to the PGI-2 locus and heading date to the ACP-1 (acid phosphatase) locus.

The other major uses of isozymes are for clonal identification, identifying hybrids, and distinguishing cultivars (Sanders \& Barker, 1988). Specific clones can be identified based on given isozyme genotypes of the clones. Hybrids can 
be determined from the genotypes of the parents that result in specific genotypes for the hybrid progeny. For example, Eizenga et al. (1990) studied the parents, hybrids, and amphiploids of three different tall fescue $\times$ giant fescue crosses for three isozyme phenotypes. A unique isozyme phenotype was shown for the individual parents and these corresponded to the isozyme phenotypes of the hybrids and amphiploids. Using four different isozymes, 15 cultivars of perennial ryegrass and six cultivars of Italian ryegrass was distinguished (Nielsen et al., 1985). Similarly, 16 of the 22 Kentucky bluegrass cultivars evaluated by Weedon and Emmo (1985) were distinguished with a combination of four different isozymes.

Banding patterns of the seed storage proteins separated on a sodium dodecylsulphate polyacrylamide gel have been used to determine differences between various forage grass cultivars. Gardiner et al. (1986) showed the potential of this analysis using perennial ryegrass, Italian ryegrass, meadow fescue, tall fescue, creeping red fescue, and chewings fescue.

The technologies for revealing DNA-based polymorphisms are the restriction fragment length polymorphism (RFLP) assay, which detects DNA polymorphisms through restriction endonuclease digestions, coupled with DNA blot hybridizations (Tanksley et al., 1989), and the random amplified polymorphic DNA (RAPD) assay which amplifies random DNA segments with a single primer(s) of an arbitrary nucleotide sequence(s) (Williams et al., 1993). The RAPD assay is easier to perform but tends to provide only dominant markers which could be a disadvantage in cool-season grasses. Use of these techniques will enable the breeder to correlate the location of DNA markers with the location of quantitative trait loci or QTLs (Ratner, 1990) and some qualitative traits such as apomixis. Additionally, in situ hybridization can be used to determine the location of these DNA markers on the chromosome.

$\mathrm{Xu}$ et al. (1991) constructed a genomic DNA library for tall fescue and surveyed the library for RFLPs in the three Festuca species: meadow fescue (2x), $F$. arundinacea var. glaucescens Bioss. $(4 \mathrm{x})$ and tall fescue $(6 \mathrm{x})$. This work has permitted more accurate determination of the genome constitution of tall fescue and represents the preliminary step in development of a low-resolution RFLP map for tall fescue. Some of these heterologous genomic clones from tall fescue also were used to detect RFLPs in perennial ryegrass (Xu et al., 1992). The RFLPs detected in perennial ryegrass were similar to those in meadow fescue and differentiated five perennial ryegrass cultivars (Fig. 14-6). More recently, cluster analysis of the RFLP data confirmed the phylogenetic relationships for tall fescue (Xu et al., 1993).

Preliminary results with ryegrass using isozymes, RFLPs, and RAPDs have identified two regions of the genome which have a large effect on inflorescence production (Hayward, 1993). In another study, using progeny from an interspecific hybridization between homozygous pearl millet $\times$ heterozygous elephantgrass, Smith et al. (1993) investigated linkage of RFLP and RAPD markers with QTLs for complex productivity and forage quality traits. The DNA markers were identified for some of these traits which were linked to genes that accounted for more than $50 \%$ of the variation associated with the given trait. For example, $63 \%$ of the variation for in vitro organic matter digestibility (IVOMD) was found to be associated with one RFLP marker. The RFLP, RAPD, and a refinement of the 


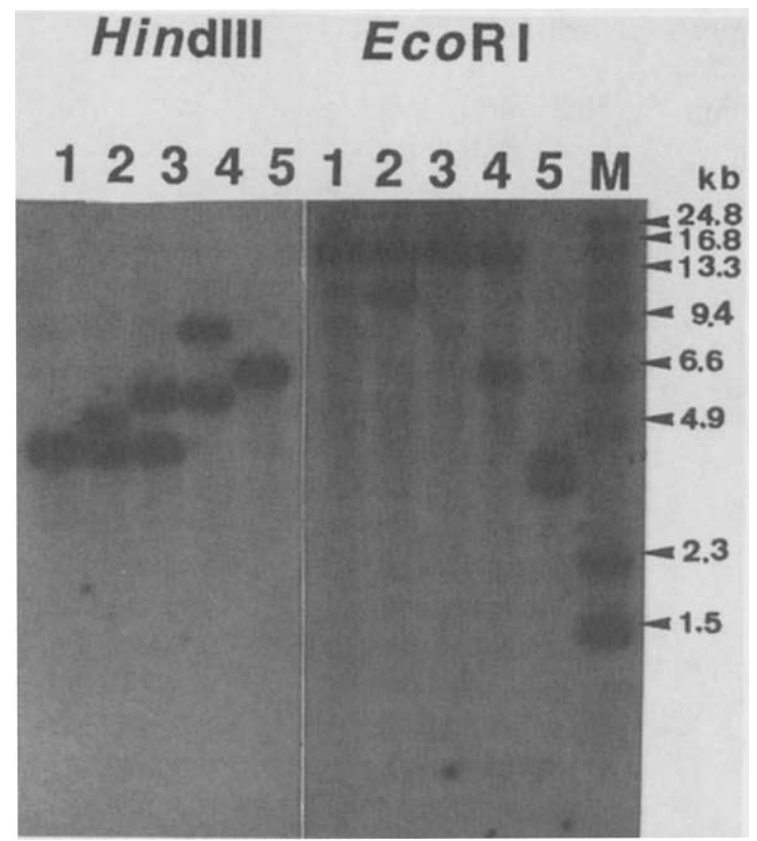

Fig. 14-6. Autoradiogram of HindIII- and EcoRI-digested genomic DNA of five cultivars of perennial ryegrass hybridized with the same probe. Lane $1=$ Derby, $2=$ Gator, $3=$ Regal, $4=$ Manhattan, $5=$ Linn, $M=$ molecular weight marker. This illustrates how the five varieties can be differentiated with a RFLP marker using two different genomic digestions. Reprinted from Xu et al. (1992).

RAPD, RAPD-DGGE (He et al., 1992), technologies had an average of 1.77, 7.5 and 10 polymorphic fragments, respectively.

With apomictic Kentucky bluegrass, Huff and Bara (1993) used flow cytometry to determine the ploidy level of the progeny and RAPD markers to distinquish apomictic versus cross-fertilized progeny. In another study, the ploidy of 34 Kentucky bluegrass cultivars was successfully determined by flow cytometry (Westerhold \& Riordan, 1992).

In situ hybridization involves hybridization of a DNA probe onto a mitotic (or meiotic) chromosome spread. This technique has been used to determine the incorporation of an introduced gene in a transgenic tall fescue plant (Wang et al., 1992) and to characterize unique repetitive DNA sequences from fescue and ryegrass species (Perez-Vicente et al., 1992). If this technique is used in conjunction with chromosome banding, it is possible to identify the chromosome to which the specific DNA sequence hybridizes. To use this technique, genetic stocks such as aneuploid lines are necessary. No trisomic or monosomic series have been reported in cool-season grass species, but there are scattered reports of cytogenetic studies on aneuploid plants such as primary trisomics of perennial ryegrass (Juahar, 1993; Lewis et al., 1980; Meijer \& Ahloowalia, 1981), primary trisomics of crested wheatgrass (Imanywoha \& Jensen, 1992), a primary trisomic of tall fescue (Jauhar, 1993), and tall fescue monosomics (Eizenga, 1989; Jauhar, 1993). 
The crested wheatgrass trisomics have been further identified by C-banding (Imanywoha \& Jensen, 1992).

A adaptation of in situ hybridization is genomic in situ hybridization (GISH) in which genomic DNA from each parental species is labeled differently through the use of (i) two different fluorochromes or (ii) biotin or fluorochrome for one parental DNA and no label for the other parental DNA. When the parental genomic DNA is hybridized to a mitotic (or meiotic) chromosome spread of a hybrid, amphiploid or polyploid plant, the chromosomes have the label of the parental species. This technique has been demonstrated with hybrids of Italian ryegrass $\times$ tall fescue (Perez-Vicente et al., 1992) and tetraploid Italian ryegrass $\times$ meadow fescue (Thomas, 1993). The potential value of this technique in hybridization is just beginning to be exploited.

\section{Conclusions}

In vitro and molecular techniques have provided a means for the plant breeder to expand the methods of creating variability. Embryo rescue has been used for decades and has proved valuable in the development of new germplasm. Technologies that involve more advanced tissue culture methods and/or molecular biology such as use of somatic hybrids via protoplast fusion and transformation require further development before the methods will be useful in the development of new germplasm. There is a need for additional genetic markers in all cool-season forage grasses. Isozymes, RFLPs, RAPDs, or maps developed from a combination of these markers will aid in identification of agronomically important loci. If the needed genetic stocks are available, in situ hybridization also can be used to locate these markers to the individual chromosomes.

\section{REFERENCES}

Acharya, S.N., B.A. Darroch, R. Hermesh, and J. Woosaree. 1992. Salt stress tolerance in native Alberta populations of slender wheatgrass and alpine bluegrass. Can. J. Plant Sci. 72:785792.

Ahloowalia, B.S. 1976. Chromosal changes in parasexually produced ryegrass. p. 115-122. In K. Jones and P.D. Brandham (ed.) Current chromosome research. Elsevier North Holland Biomed.Press, Amsterdam.

Ahmad, I., S.J. Wainwright, and G.R. Stewart. 1981. The solute and water relations of Agrostis stolonifera ecotypes differing in their salt tolerance. New Phytol. 87:615-629.

Al-Hiyaly, S.A.K., T. McNeilly, A.D. Bradshaw, and A.M. Mortimer.1993. The effect of zinc contamination from electricity pylons. Genetic constraints on selection for zinc tolerance. Heredity 70:22-32.

Antonovics, J. 1975. Metal tolerance in plants: Perfecting an evolutionary paradigm. p. 169-186. In T.C. Hutchinson et al. (ed.) Int. Conf. Heavy Metals Environ. Vol 2, Toronto, Canada. 27-31 October. Inst. Environ. Studies, Toronto.

Antonovics, J., A.D. Bradshaw, and R.G. Turner. 1971. Heavy metal tolerance in plants. Adv. Ecol. Res. 7:1-85.

Allard, R.W. 1960. Principles of plant breeding. John Wiley \& Sons, Inc., New York, London, Sydney.

Anderson, B., J.K. Ward, K.P. Vogel, H.J. Gorz, and F.A. Haskins. 1988. Forage quality and performance of yearlings grazing switchgrass strains selected for differing digestibility. J. Anim. Sci. 66:2239-2244.

Arnold, B.L., C.E. Watson, Jr., and N.C. Edwards, Jr. 1981. Registration of Marshall annual ryegrass. Crop Sci. 21:474-475. 
Arnold, G.W. 1981. Grazing behaviour. p. 79-104. In F.H.W. Morley (ed.) World animal science, B1. Elsevier, Amsterdam.

Arnold, G.W. 1987. Grazing behaviour p. 129-136. In R.W. Snaydon (ed.) Ecosystems of the world, 17B. Elsevier, Amsterdam.

Asano, Y., and K. Sugiura. 1990. Plant regeneration from suspension culture-derived protoplasts of Asrostis alba L. (Redtop). Plant Sci. 72:267-273.

Asay, K.H. 1992. Breeding potentials in perennial Triticeae grasses. Hereditas 116:167-173.

Asay, K.H., D.R. Dewey, F.B. Gomm, D.A. Johnson, and J.R. Carlson. 1985. Registration of 'Hycrest' crested wheatgrass (Reg. No. 16). Crop Sci. 25:368-369.

Asay, K.H., D.R. Dewey, W.H. Horton, K.B. Jensen, P.O. Currie, N.J. Chatterton, W.T. Hansen II, and J.R. Carlson. 1991. Registration of 'HewHy' RS wheatgrass. Crop Sci. 31:1384-1385.

Asay, K.H., and K.B. Jensen. 1996a. Wheatgrasses. p. 691-724. In L.E. Moser et al. (ed.) Coolseason forage grasses. Agron. Monogr. 34. ASA, CSSA, and SSSA, Madison, WI.

Asay, K.H., and K.B. Jensen. 1996b. Wildryes. p. 725-748. In L.E. Moser et al. (ed.) Cool-season forage grasses. Agron. Monogr. 34. ASA, CSSA, and SSSA, Madison, WI.

Asay, K.H., and D.A. Johnson. 1980. Screening for improved stand establishment in Russian wild ryegrass. Can. J. Plant Sci. 60:1171-1177.

Ashraf, M., T. McNeilly, and A.D. Bradshaw. 1986a. The potential for evolution of salt $(\mathrm{NaCl})$ tolerance in seven grass species. New Phytol. 103:299-309.

Ashraf, M., T. McNeilly, and A.D. Bradshaw. 1986b. The response of selected salt-tolerant and normal lines of four grass species to $\mathrm{NaCl}$ in sand culture. New Phytol. 104:453-461.

Aung, T. 1991. Intergeneric hybrids between Hordeum vulgare and Elymus trachycaulus resistant to Russian wheat aphid. Genome 34:954-960.

Ayazloo, M., S.G. Garsed, and J.N.B. Bell. 1982. Studies on the tolerance to sulphur dioxide of grass populations in polluted areas. II. Morphological and physiological investigations. New Phytol. 90:109-126.

Badoux, S. 1979. Relations between climatic conditions and growth of alpine fodder plant ecotypes. p. 51-56. In S. Ceccarelli (ed.) Breeding for stress conditions. Proc. Eur. Assoc. Res. Plant Breed. (EUCARPIA) 4-6 September. Ist. Allevament. Veg., Perugia, Italy.

Baker, A.J.M., C.J. Grant, M.H. Martin, S.C. Shaw, and J. Whitebrook. 1986. Induction and loss of cadmium tolerance in Holcus lanatus L. and other grasses. New Phytol. 102:575-587.

Ballerstedt, P.J., W.C. Young, III, D. Floyd, and T. Silberstein. 1990. Evaluation of the forage and seed production potential of rescuegrass (prairie grass) in western Oregon. p. 185. In Agronomy abstracts. ASA, Madison, WI.

Barker, R.E., M.D. Casler, I.T. Carlson, D.A. Sleper, C.C. Berg, and W.C. Young III. 1993. Convergent-divergent selection for seed yield and forage traits in orchardgrass. II. Seed yield response in Oregon. p. 81. In Agronomy abstracts. ASA, Madison, WI.

Barker, R.E., and R.R. Kalton. 1989. Cool-season forage grass breeding: Progress, potentials, and benefits. p. 5-20. In D.A. Sleper et al. (ed.) Contributions from breeding forage and turf grasses. CSSA Spec. Publ. 15. ASA, Madison, WI.

Beddows, A.R. 1953. The ryegrasses in British agriculture: A survey. Welsh P1. Breed. Stn. Bull. Ser. H, no. 17. Welsh Plant Breed. Stn., Aberystwyth, Ltd.

Beddows, A.R. 1968. A history of the introduction of timothy and cocksfoot into alternate husbandry in Britain. 1. The year 1763 and its significance. J. Br. Grassl. Soc. 23:317-321.

Beddows, A.R. 1969a. A history of the introduction of timothy and cocksfoot into alternate husbandry in Britain. 2. The impact of timothy on ley farming. J. Br. Grassl. Soc. 24:40-44.

Beddows, A.R. 1969b. A history of the introduction of timothy and cocksfoot into alternate husbandry in Britain. 3. The impact of cocksfoot on ley farming. J. Br. Grassl. Soc. 24:163167.

Bell, J.N.B., M. Ayazloo, and G.B. Wilson. 1982. Selection for sulphur dioxide tolerance in grass populations in polluted areas. p. 171-180. In R. Bornkamm et al. (ed.) Urban ecology, Berlin, Germany. 6-12 Sept. 1980. Blackwell Sci. Publ., Oxford, England.

Berdahl, J.D., and R.E. Barker. 1984. Selection for improved seedling vigor in Russian wild ryegrass. Can. J. Plant Sci. 64:131-138.

Berg, C.C., M.D. Casler, I.T. Carlson, and D.A. Sleper. 1993. Convergent-divergent selection for seed yield and forage traits in orchardgrass. III. Forage trait response. p. 82. In Agronomy abstracts. ASA, Madison, WI.

Berg, C.C., R.R. Hill Jr., R.C. Buckner, and R.F Barnes. 1979. Forage production and quality of synthetics derived from Lolium $\times$ Festuca hybrids. Crop Sci. 19:89-93.

Berg, C.C., A.R. McElroy, and H.T. Kunelius. 1996. Timothy, p. 643-664. In L.E. Moser et al. (ed.) Cool-season forage grasses. Agron. Monogr. 34. ASA, CSSA, and SSSA, Madison, WI. 
Berg, C.C., R.T. Sherwood, and K.E. Zeiders. 1986. Recurrent phenotypic selection for resistance to brown leaf spot in smooth bromegrass. Crop Sci. 26:533-536.

Berg, C.C., G.M. Wood, A.W. Hovin, and C.M. Rincker. 1981. Floral induction and forage yield and quality of sparse-flowering orchardgrass synthetics. Crop Sci. 21:677-680.

Boe, A., and R.H. Delaney. 1996. Creeping and meadow foxtail. p. 749-763. In L.E. Moser et al. (ed.) Cool-season forage grasses. Agron. Monogr. 34. ASA, CSSA, and SSSA, Madison, WI.

Boppenmeier, J., S. Zuchner, and B. Foroughi-Wehr. 1989. Haploid production from barley yellow dwarf virus resistant clones of Lolium. Plant Breed. 103:216-220.

Bradshaw, A.D. 1974. The evolutionary lessons of metal tolerance. Heredity 33:450.

Bradshaw, A.D. 1976. Pollution and evolution. p. 135-159. In T.A. Mansfield (ed.) Effects of air pollutants on plants. Cambridge Univ. Press, Cambridge, MA.

Braverman, S.W. 1986. Disease resistance in cool-season forage range and turf grasses II. Bot. Rev. 52:1-112.

Breese, E.L. 1983. Exploitation of the genetic resources through breeding: Lolium species. p. 275288. In J.G. McIvor and R.A. Bray (ed.) Genetic resources of forage plants. CSIRO, East Melbourne, Australia.

Breese, E.L., and W.E. Davies. 1970. Selection for factors affecting nutritive value. p. 33-37. In Ann. Rep. Welsh Plant Breed. Stn. for 1969. Aberystwyth, Wales.

Breese, E.L., and C.A. Foster. 1971. Breeding for increased winter hardiness in perennial ryegrass. p. 77-86. In Welsh Plant Breed. Stn. Ann. Rep. for 1970. Welsh Plant Breed. Stn., Aberystwyth, Wales.

Breese, E.L., and M.D. Hayward. 1972. The genetic basis of present breeding methods in forage crops. Euphytica 21:324-336.

Breese, E.L., and B.F. Tyler. 1986. Patterns of variation and the underlying genetic and cytological architecture in grasses with particular reference to Lolium p. 53-69. In B.T. Styles (ed.) Infraspecific classification of wild and cultivated plants. Clarendon Press, Oxford, England.

Brougham, R.W., A.C. Glenday, and S.O. Fejer. 1960. The effects of frequency and intensify of grazing on the genotypic structure of a ryegrass population. N.Z. J. Agric. Res. 3:442-453.

Brougham, R.W., and W. Harris. 1967. Rapidity and extent of changes in genotypic structure induced by grazing in a ryegrass population. N.Z. J. Agric. Res. 10:56-65.

Bruckner, P.L., P.L. Raymer, and G.W. Burton. 1991. Recurrent phenotypic selection for forage yield in rye. Euphytica 54:11-17.

Buckner, R.C. 1962. CLAIR. Crop Sci. 2:355.

Buckner, R.C., J.A. Boling, P.B. Burrus, II, L.P. Bush, and R.A. Hemken. 1983. Registration of Johnstone tall fescue. Crop Sci. 23:399-400.

Buckner, R.C., P.B. Burrus, II, and L.P. Bush. 1977. Registration of Kenhy tall fescue. Crop Sci. 17:672-673.

Buckner, R.C., L.P. Bush, and P.B. Burrus, II. 1979. Succulence as a selection criterion for improved forage quality in Lolium-Festuca hybrids. Crop Sci. 19:93-96.

Burner, D.M., J.A. Balasko, and P.M. O'Brien. 1988. Attributes of tall fescue germplasm of diverse geographic origin. Crop Sci. 28:459-462.

Burton, G.W. 1974. Recurrent restricted phenotypic selection increases forage yields of pensacola bahiagrass. Crop Sci. 14:831-834.

Burton, G.W., and W.G. Monson. 1988. Registration of 'Tifton 78' bermudagrass. Crop Sci. 28:187188.

Buxton, D.R., and M.D. Casler. 1993. Environmental and genetic effects on cell wall composition and degradability. p. 685-714. In H.G. Jung et al. (ed.) Forage cell wall structure and digestibility. ASA, CSSA, and SSSA, Madison, WI.

Buxton, D.R., J.S. Hornstein, and G.C. Marten. 1987. Genetic variation for forage quality of alfalfa stems. Can. J. Plant Sci. 67:1057-1067.

Byers, R.A., and R.T. Sherwood. 1979. Differential reaction of clones of Phalaris arundinacea to Oscinella frit. Environ. Entomol. 8:408-411.

Carlson, I.T. 1985. Breeding for increased forage yield in reed canarygrass. p. 282-283. In Proc. 15th Int. Grassl. Conf., Kyoto, Japan. 24-31 August. Jpn. Soc. Grassl. Sci., Nishi-nasuno, Tochigi-ken, Japan.

Carlson, I.T. 1990. Direct and indirect selection for forage yield in reed canarygrass. p. 83-84. In Agronomy abstracts. ASA, Madison, WI.

Carlson, I.T., D.K. Christensen, and R.B. Pearce. 1983. Selection for specific leaf weight in reed canarygrass and its effects on the plant. p. 207-209. In J.A. Smith and V.W. Hays (ed.) Proc. 14th Int. Grassl. Congr., Lexington, KY. 15-24 June 1981. Westview Press, Boulder, $\mathrm{CO}$. 
Carlson, I.T., R.N. Oram, and J. Suprenant. 1995. Reed canarygrass and other Phalaris species. p. 569-604. In L.E. Moser et al. (ed.) Cool-season forage grasses. Agron. Monogr. 34. ASA, CSSA, and SSSA, Madison, WI.

Carpenter, J.A., and M.D. Casler. 1990. Divergent phenotypic selection response in smooth bromegrass for forage yield and nutritive value. Crop Sci. 30:17-22.

Casler, M.D. 1988. Performance of orchardgrass, smooth bromegrass, and ryegrass in binary mixtures with alfalfa. Agron. J. 80:509-514.

Casler, M.D. 1990. Cultivar and cultivar $\times$ environment effects on relative feed value of temperate perennial grasses. Crop Sci. 30:722-728.

Casler, M.D. 1991. Genetic variation and covariation in a population of tetraploid Dactylis L. accessions. Theor. Appl. Genet. 81:253-264.

Casler, M.D., and P.N. Drolsom. 1992. Registration of 'Badger' smooth bromegrass. Crop Sci. 32:1073-1074.

Casler, M.D., J.A. Carpenter, and J.R. Attewell. 1989. Selection strategies for developing smooth bromegrass cell wall ideotypes. Theor. Appl. Genet. 70:775-782.

Casler, M.D., and N.J. Ehlke. 1986. Forage yield and yield component changes with divergent selection for in vitro dry matter digestibility of smooth bromegrass. Crop Sci. 26:478-481.

Casler, M.D., and A.W. Hovin. 1985. Predicting forage yield from morphological traits in reed canarygrass. Crop Sci. 25:783-787.

Casler, M.D., D.A. Sleper, I.T. Carlson, C.C. Berg, and R.E. Barker. 1993. Convergent-divergent selection for seed yield and forage traits in orchardgrass. I. Direct selection responses. p. 84. In Agronomy abstracts. ASA, Madison, WI.

Casler, M.D., and R.P. Walgenbach. 1990. Ground cover potential of forage grass cultivars mixed with alfalfa at divergent locations. Crop Sci. 30:825-831.

Catherall, P.L. 1987. Selection of cocksfoot (Dactylis glomerata) with resistances to cocksfoot mottle virus. Tests Agrochem. Cult. 8:144-145.

Ceccarelli, S., M. Falcinelli, and F. Damiani. 1980. Selection for dry matter yield in Lolium perenne L. I. Direct response to selection. Can. J. Plant Sci. 60:491-500.

Ceccarelli, S., M. Falcinelli, and F. Damiani. 1981. Selection for seed yield in Lolium perenne L. Genet. Agrar. 35:131-146.

Ceccarelli, S., E. Falistocco, and P.G. Cionini. 1992. Variation of genome size and organization within hexaploid Festuca arundinacea. Theor. Appl. Genet. 83:273-278.

Chamberlain, J.A., and P.E. Evans. 1979. Relationship between depth of leaf ridging and numbers of a possible mite vector. p. 197-198. In Welsh Plant Breed. Stn. Ann. Rep. for 1978. Welsh plant breed. Stn., Aberystwyth, Wales.

Charles, A.H. 1961. Differential survival of cultivars of Lolium, Dactylis, and Phleum. J. Br. Grassl. Soc. 16:69-75.

Charles, A.H. 1964. Differential survival of plant types in swards. J. Br. Grassl. Soc. 19:198-204.

Charles, A.H. 1972. Ryegrass populations from intensively managed leys. III. Reaction to management, nitrogen application and Poa trivialis L. in field trials. J. Agric. Sci. 79:205-215.

Christie, B.R., and D.N. Mowat. 1968. Variability of in vitro digestibility among clones of bromegrass and orchardgrass. Can. J. Plant Sci. 48:67-73.

Churchill, B.R. 1947. Productiveness of bromegrass strains from different regions when grown in pure stands and in mixture with alfalfa in Michigan. J. Am. Soc. Agron. 39:750-761.

Clay, K. 1990. Fungal endophytes of grasses. Ann. Rev. Ecol. Syst. 21:275-297.

Clements, R.J. 1969. Selection for crude protein content in Phalaris tuberosa L. I. Response to selection and preliminary studies on correlated response. Aust. J. Agric. Res. 20:643-652.

Coleman, S.W., T.D.A. Forbes, and J.W. Stuth. 1989. Measurements of the plant-animal interface in grazing research. p. 37-51. In G.C. Marten (ed.) Grazing research: Design, methodology, and analysis. CSSA Spec. Publ. 16. CSSA, Madison, WI.

Collins, M., and P.N. Drolsom. 1982. Composition and digestibility of smooth bromegrass clones selected for high and low IVDMD. Agron. J. 74:287-290.

Conger, B.V. 1991. Applications of cell and tissue culture to forage grass breeding. p. 67-78. In D.A. Sleper (ed.) Proc. 31st Grass Breeders Work Planning Conf., Columbia, MO. 5-6 August. Grass Breed. Work Planning Conf., Mandan, ND.

Conger, B.V., and R.E. McDonnell. 1983. Plantlet formation from cultured inflorescences of Dactylis glomerata L. Plant Cell Tiss. Org. Cult. 2:191-197.

Cook, S.C.A., C. Lefébvre, and T. McNeilly. 1972. Competition between metal tolerant and normal plant populations on normal soil. Evolution 26:366-372.

Cooper, J.P. 1959. Selection and population structure in Lolium. III. Selection for date of ear emergence. Heredity 13:461-479. 
Cooper, J.P. 1960. Selection and population structure in Lolium. IV. Correlated response to selection. Heredity 14:229-246.

Cornish, M.A., M.D. Hayward, and M.J. Lawrence. 1980. Self-incompatibility in ryegrass. III. The joint segregation of S and PGI-2 in Lolium perenne L. Heredity 44:55-62.

Coulaud, J., and T. McNeilly. 1992. Zinc tolerance in populations of Deschampsia cespitosa (Gramineae) beneath electricity pylons. Plant Syst. Evol. 179:175-185.

Cox, R.M., and T.C. Hutchinson. 1980. Multiple metal tolerances in the grass Deschampsia cespitosa (L.) Beauv. from the Sudbury smelting area. New Phytol. 84:631-647.

Creemers-Molenaar, J., R.D. Hall, and F.A. Krens. 1992. Asymmetric protoplast fusion aimed at intraspecific transfer of cytoplasmic male sterility (CMS) in Lolium perenne L. Theor. Appl. Genet. 84:763-770.

Creemers-Molenaar, J., J.P.M. Loeffen, and P. VanDerValk. 1988. The effect of 2,4dichlorophenoxyacetic acid and donor plant environment on plant regeneration from immature inflorescence-derived callus of Lolium perenne L. and Lolium multiflorum Lam. Plant Sci. 57:165-172.

Creemers-Molenaar, J., P. Van Der Valk, J.P.M. Loeffen, and M.A.C.M. Zaal. 1989. Plant regeneration from suspension cultures and protoplasts of Lolium perenne L. Plant Sci. 63:167176.

Crossley, G.K., and A.D. Bradshaw. 1968. Differences in response to mineral nutrients of populations of ryegrass, Lolium perenne L., and orchardgrass, Dactylis glomerata L. Crop Sci. 8:383-387.

Dahleen, L.S., and G.C. Eizenga. 1990. Meiotic and isozymic characterization of plants regenerated from euploid and selfed monosomic tall fescue embryos. Theor. Appl. Genet. 79:3944.

Dale, P.J. 1977a. Meristem tip culture in Lolium, Festuca, Phleum, and Dactylis. Plant Sci. Lett. 9:333-338.

Dale, P.J. 1977b. The elimination of ryegrass mosaic virus from Lolium multiflorum by meristem tip culture. Ann. Appl. Biol. 85:93-96.

Dale, P.J. 1980. A method for in vitro storage of Lolium multiflorum Lam. Ann. Bot. 45:497-502.

Dale, P.J., and S.J. Dalton. 1983. Immature inflorescence culture in Lolium, Festuca, Phleum, and Dactylis. Z. Pflanzenphysiol. 111:39-45.

Dalton, S.J. 1988a. Plant regenetation from cell suspension protoplasts of Festuca arundinacea Schreb., Lolium perenne L., and L. multiflorum Lam. Plant Cell Tiss. Org. Cult. 12:137140.

Dalton, S.J. 1988b. Plant regeneration from cell suspension protoplasts of Festuca arundinacea Schreb. (tall fescue) and Lolium perenne L. (perennial ryegrass). J. Plant Physiol. 132:170175.

Darwin, C. 1868. The variation of animals and plants under domestication. Murray, London.

Darwin, C. 1875. The variation of animals and plants under domestication. 2nd ed. Murray, London.

Davies, I. 1976. Developmental characteristics of grass varieties in relation to their herbage production. 1. An analysis of high-digestibility varieties of Dactylis glomerata at three stages of development. J. Agric. Sci. 87:25-32.

Davies, M.S., and R.W. Snaydon. 1973a. Physiological differences among populations of Anthoxanthum odoratum L. collected from the Park Grass Experiment, Rothamstead. I. Response to Calcium. J. Appl Ecol. 10:33-45.

Davies, M.S., and R.W. Snaydon. 1973b. Physiological differences among populations of Anthoxanthum odoratum L. collected from the Park Grass Experiment, Rothamstead. II. Response to Aluminum. J. Appl Ecol. 10:47-55.

Davies, M.S., and R.W. Snaydon. 1974. Physiological differences among populations of Anthoxanthum odoratum L. collected from the Park Grass Experiment, Rothamstead. III. Response to Phosphate. J. Appl. Ecol. 11:699-707.

Davies, M.S., and R.W. Snaydon. 1976. Rapid population differentiation in a mosaic environment. III. Measures of selection pressures. Heredity 36:59-66.

Davies, W.E., B.F. Tyler, M. Borrill, J.P. Cooper, H. Thomas, and E.L. Breese. 1973. Plant introduction at the Welsh Plant Breeding Station. p. 143-162. In Welsh Plant Breed. Stn. Ann. Rep. for 1972. Welsh Plant Breed. Stn., Aberystwyth, Wales.

Davison, A.W., and I.F. Bailey. 1982. $\mathrm{SO}_{2}$ pollution reduces the freezing resistance of ryegrass. Nature (London) 297:400-402.

Dewey, D.R. 1962. Breeding crested wheatgrass for salt tolerance. Crop Sci. 2:403-407. 
Dewey, D.R. 1980. Some applications and misapplications of induced polyploidy to plant breeding. p. 445-470. In W.H. Lewis (ed.) Polyploidy: Biological relevance. Plenum Publ. Corp., New York.

Ehlke, N.J., M.D. Casler,P.N. Drolsom, and J.S. Shenk. 1986. Divergent selection for in vitro dry matter digestibility in smooth bromegrass. Crop Sci. 26:1123-1126.

Eizenga, G.C. 1989. Meiotic analyses of tall fescue somaclones. Genome 32:373-379.

Eizenga, G.C., and R.C. Buckner. 1986. Cytological and isozyme evaluation of tall fescue $\times$ Italian ryegrass hybrids. Plant Breed. 97:340-344.

Eizenga, G.C., D.M. Burner, and R.C. Buckner. 1990. Meiotic and isozymic analysis of tall fescue $\times$ giant fescue hybrids and amphiploids. Plant Breed. 104:202-211.

Eizenga, G.C., and P.L. Cornelius. 1991. Comparison of the isozyme variation in tall fescue parents and their somaclones. Euphytica 51:249-256.

Eizenga, G.C., and L.S. Dahleen. 1990. Callus production, regeneration and evaluation of plants from cultured inflorescences of tall fescue (Festuca arundinacea Schreb.). Plant Cell Tiss. Org. Cult. 22:7-15.

Eizenga, G.C., and M.J. Kasperbauer. 1985. Chromosome pairing in tall fescue haploids derived by anther-panicle culture. J. Hered. 76:99-103.

Ellenberg, H. 1963. Vegetation Mitteleuropas mit den Alpen in kavsaler, dynamischer und historisher Sicht. In H. Walter (ed.) Einführung in die Phytologie. Vol. 4. Part 2. Stuttgart, Germany.

Ernst, W. 1976. Physiological and biochemical aspects of metal tolerance. p. 115-133. In T.A. Mansfield (ed.) Effects of air pollutants on plants. Cambridge Univ. Press, Cambridge.

Evans, D.R., J. Hill, T.A. Williams, and I. Rhodes. 1989. Coexistence and the productivity of white clover-perennial ryegrass mixtures. Theor. Appl. Genet. 77:65-70.

Evans, G., W.E. Davies, and A.H. Charles. 1961. Shift and the production of authenticated seed of herbage cultivars. p. 99-105. In Welsh Plant Breed. Stn. Ann. Rep. 1960. Welsh Plant Breed. Stn., Aberystywth, Wales.

Evans, M.W. 1937. Improvement of timothy. p. 1103-1121. In Yearbook of agriculture, 1937. U.S. Govt. Print. Office, Washington, DC.

Falcinelli, M. 1991. Backcross breeding to increase seed retention in cocksfoot (Dactylis glomerata L.). Euphytica 56:133-135.

Falconer, D.S. 1989. Introduction to quantitative genetics. 3rd ed. Longman Group UK Ltd., Essex, England.

Fergus, E.N., and R.C. Buckner. 1972. Registration of Kentucky 31 tall fescue. Crop Sci. 12:714.

Fily, M., C. Tosca, and G. Balent. 1991. Réaction à un composé salivaire et tolérance à la coupe de génotypes de Dactylis glomerata L issus de populations ayant une expérience contrastée du pâturage. Agronomie 11:247-257.

Forde, M.B., and F.E.T. Suckling. 1980. Genetic resources in high-rainfall hill pastures of New Zealand. N.Z. J. Agric. Res. 23:179-189.

Francis, A., and R.N. Jones. 1989. Heritable nature of colchicine induced variation in diploid Lolium perenne. Heredity 62:407-410.

Frandsen, K.J. 1949. Forædling af fremmedbefrugtere. Resultater of erfaringer fra forædlingsarbejdet med fremmedbefrugtende planter. Nordisk Jordbrugsfors. 31:233-253.

Frandsen, K.J. 1986. Variability and inheritance of digestibility in perennial ryegrass (Lolium perenne), meadow fescue (Festuca pratensis), and cocksfoot (Dactylis glomerata). II. $\mathrm{F}_{1}$ and $F_{2}$ progeny. Acta Agric. Scand. 36:241-263.

Frandsen, K.J. 1991. A Danish plant breeding enterprise. Danish Plant Breeding, Boelshøj, Denmark.

Fujimoto, F., and S. Suzuki. 1975. Studies on variation and selection in Italian ryegrass populations. III. Response to selection for higher dry matter weight. Jpn. J. Breed. 25:323-333.

Gallais, A. 1992. Porquoi faire des variétés synthétiques? Agronomie 12:601-609.

Gardiner, S.E., M.S. Fords, and C.R. Slack. 1986. Grass cultivar identification by sodium dodecylsulphate polyacrylamide gel electrophoresis. N.Z. J. Agric. Res. 29:193-206.

Gardner, C.O. 1961. An evaluation of effects of mass selection and seed irradiation with thermal neutrons on yield of corn. Crop Sci. 1:241-245.

Gartside, D.W., and T. McNeilly. 1974. The potential for evolution of heavy metal tolerance in plants. II. Copper tolerance in normal populations of different plant species. Heredity 32:335348.

Gately, T.F. 1984. Early versus late perennial ryegrass (Lolium perenne) for milk production. Ir. J. Agric. Res. 23:1-9. 
Gay, A.P. 1986. Variation in selection for leaf water conductance in relation to growth and stomatal dimensions in Lolium perenne L. Ann. Bot. 57:361-369.

Gay, A.P. 1989. Assessment of the response to selection for leaf water conductance in Lolium perenne. Ann. Bot. 64:593-598.

Gay, A.P., and C.F. Eagles. 1991. Quantitative analysis of cold hardening and dehardening in Lolium. Ann. Bot. 67:339-345.

Gray, D.J., and A. Purohit. 1991. Somatic embryogenesis and development of synthetic seed technology. Crit. Rev. Plant Sci. 10:33-61.

Gregor, J.W., and F.W. Sansome. 1927. Experiments on the genetics of wild populations. Part I. Grasses. J. Genet. 17:349-364.

Gregory, R.P.G., and A.D. Bradshaw. 1965. Heavy metal tolerance in populations of Agrostis tenuis Sibth and other grasses. New Phytol. 64:131-143.

Greub, L.J., M. Collins, S.K. Carlson, and M.D. Casler. 1986. Relationship of morphological characteristics to forage quality in quackgrass. Crop Sci. 26:819-822.

Ha, S.-B., F.-S. Wu, and T.K. Thorne. 1992. Transgenic turf-type tall fescue (Festuca arundinacea Schreb.) plants regenerated from protoplasts. Plant Cell Rep. 11:601-604.

Hacker, J.B. 1982. Selection and breeding better quality grasses. p. 355-326. In J.B. Hacker (ed.) Nutritional limits to animal production from pastures. Commonw. Agric. Bur., Farnham House, Farnham Royal, Slough, England.

Hague, L.M., and R.N. Jones. 1987. Cytogenetics of Lolium perenne. IV. Colchicine induced variation in diploids. Theor. Appl. Genet. 74:233-241.

Hallauer, A.R., and J.B. Miranda Fo. 1981. Quantitative genetics in maize breeding. Iowa State Univ. Press, Ames, IA.

Hanna, W.W., and R.R. Hill, Jr. 1985. Forage crop breeding. p. 80-88. In M.E. Heath, R.F Barnes, and D.S. Metcalfe (ed.) Forages, 4th ed. Iowa State Univ. Press, Ames, IA.

Hannon, N., and A.D. Bradshaw. 1968. Evolution of salt tolerance in two coexisting species of grass. Nature (London) 220:1342-1343.

Hanson, A.A. 1972. Breeding of grasses. p. 36-52. In V.B. Youngner and C.M. McKell (ed.) The biology and utilization of grasses. Acad. Press, New York.

Hanson, A.A., and H.L. Carnahan. 1956. Breeding perennial forage grasses. USDA Tech. Bull. 1145. U.S. Gov. Print. Office, Washington, DC.

Harberd, D.J. 1962. Some observations on natural clones in Festuca ovina. New Phytol. 61:85100 .

Harberd, D.J. 1961. Observations on population structure and longevity of Festuca rubra L. New Phytol. 60:184-206.

Harlan, J.R. 1975. Crops and man. CSSA and ASA, Madison, WI.

Harlan, J.R., and J.M.J. deWet. 1975. On Ö. Winge and a prayer: The origins of polyploidy. Bot. Rev. 41:361-390.

Hays, W.M. 1892. Improvement of timothy. Minnesota Agric. Exp. Stn. Bull. 20:45-46.

Hayward, M.D. 1970. Selection and survival in Lolium perenne L. Heredity 25:441-447.

Hayward, M.D. 1977. Genetic control of resistance to crown rust (Puccinia coranato Corda) in Lolium perenne L. and its implications in breeding. Theor. Appl. Genet. 51:49-53.

Hayward, M.D. 1983. Selection for yield in Lolium perenne. I. Selection and performance under spaced plant conditions. Euphytica 32:85-95.

Hayward, M.D. 1988. Exploitation of the incompatability mechanism for the production of $F_{1}$ hybrid forage grasses. Euphytica 39:33-37.

Hayward, M.D. 1992. Association of agronomic traits with isozyme loci in perennial ryegrass (Lolium perenne L.). Euphytica 59:141-150.

Hayward, M.D. 1993. Genome mapping and QTL analysis in Lolium. p. 25. In AFRC Inst. Grassl. Environ. Res. Rep. 1992. Welsh Plant Breed. Stn., Aberystwyth, Wales.

Hayward, M.D., and I.B. Abdullah. 1985. Selection and stability of synthetic varieties of Lolium perenne. 1. The selected character and its expression over generations of multiplication. Theor. Appl. Genet. 70:48-51.

Hayward, M.D., I.H. DeLacey, B.F. Tyler, and D.W. Drake. 1982. The application of pattern analysis for the recognition of adaptation in a collection of Lolium multiflorum populations. Euphytica 31:383-396.

Hayward, M.D., and J.L. Vivero. 1984. Selection for yield in Lolium perenne. II. Performance of spaced plant selections under competitive conditions. Euphytica 33:787-800.

$\mathrm{He}, \mathrm{S} ., \mathrm{H}$. Ohm, and S. Mackenzie. 1992. Detection of DNA sequence polymorphisms among wheat varieties. Theor. Appl. Genet. 84:573-578. 
Hein, M.A. 1955. Registration of varieties and strains of bromegrass (Bromus spp.). II. Lincoln smooth bromegrass. Agron. J. 47:533-534.

Hewitt, G.B. 1980. Tolerance of ten species of Agropyron to feeding by Labops hesperius. J. Econ. Entomol. 73:779-782.

Hickey, D.A., and T. McNeilly. 1975. Competition between metal tolerant and normal plant populations; a field experiment on normal soil. Evolution 29:458-464.

Hides, D.H. 1978. Winter hardiness in Lolium multiflorum Lam. II. The effect of defoliation and nitrogen application as assessed by low temperature response in a controlled environment. J. Br. Grassl. Soc. 33:175-179.

Hides, D.H. 1979. Winter hardiness in Lolium multiflorum Lam. III. Selection for improved cold tolerance and its effect on agronomic performance. Grass Forage Sci. 34:119-124.

Hides, D.H., C.A. Kute, and A.H. Marshall. 1993. Seed development and seed yield potential of Italian ryegrass (Lolium multiflorum Lam.) populations. Grass Forage Sci. 48:181-188.

Hides, D.H., and P.W. Wilkins. 1978. Selection for resistance to ryegrass mosaic virus and crown rust (Puccinia coronata Corda) in Italian ryegrass populations. J. Br. Grassl. Soc. 33:253260.

Horn, M.E., B.V. Conger, and C.T. Harms. 1988a. Plant regeneration from protoplasts of embryogenic suspension cultures of orchardgrass (Dactylis glomerata L.). Plant Cell Rep. 7:371374.

Horn, M.E., R.D. Shillito, B.V. Conger, and C.T. Harms. 1988b. Transgenic plants of orchardgrass (Dactylis glomerata L.) from protoplasts. Plant Cell Rep. 7:469-472.

Horsman, D.C., T.M. Roberts, and A.D. Bradshaw. 1979. Studies on the effect of sulphur dioxide on perennial ryegrass (Lolium perenne L.). II. Evolution of sulphur dioxide tolerance. J. Exp. Bot. 30:495-501.

Hovin, A.W. 1980. Cool-season grasses. p. 285-298. In W.R. Fehr and H.H. Hadley (ed.) Hybridization of crop plants. ASA, CSSA, Madison, WI.

Hovin, A.W., G.C. Marten, and R.E. Stucker. 1976. Cell wall constituents of reed canarygrass: Genetic variability and relationship to digestibility and yield. Crop Sci. 16:575-578.

Hovin, A.W., C.M. Rincker, and G.M Wood. 1966. Breeding of nonflowering orchardgrass, Dactylis glomerata L. Crop Sci. 6:239-241.

Huff, D.R., and J.M. Bara. 1993. Determining genetic origins of aberrant progeny from facultative apomictic Kentucky bluegrass using a combination of flow cytometry and silver-stained RAPD markers. Theor. Appl. Genet. 87:201-208.

Humphreys, M.O. 1989a. Assessment of perennial ryegrass (Lolium perenne L.) for breeding. II. Components of winter hardiness. Euphytica 41:99-106.

Humphreys, M.O. 1989b. Water-soluble carbohydrates in perennial ryegrass breeding. II. Cultivar and hybrid progeny performance in cut plots. Grass Forage Sci. 44:237-244.

Humphreys, M.O. 1989c. Breeding for quality in perennial ryegrass. p. 22 In O. Jewiss and C. Eagles (ed.) AFRC Int. Grassl. Anim. Prod. Ann. Rep. for 1988. Vol. 2. Welsh Plant Breed. Stn., Aberystwyth, Wales.

Humphreys, M.O., and A.D. Bradshaw. 1977. Genetic potentials for solving problems of soil mineral stress: heavy metal toxicities. p. 95-123. In M.J. Weight (ed.) Plant adaptation to mineral stress in problem soils. Cornell Univ., Ithaca, NY.

Humphreys, M.O., and C.F. Eagles. 1988. Assessment of perennial ryegrass (Lolium perenne L.) for breeding. I. Freezing tolerance. Euphytica 38:75-84.

Humphreys, M.W., and S.J. Dalton. 1992. Stability at the phosphoglucoisomerase (PGI/2) locus in Lolium multiflorum $(2 n=4 x=28) \times$ Festuca arundinacea $(2 n=6 x=42)$ plants regenerated from cell suspension. Genome 35:461-467.

Hunt, W.F., and H.S. Easton. 1989. Fifty years of ryegrass research in New Zealand. Proc. N.Z. Grassl. Assoc. 50:11-23.

Imanywoha, J., and K.B. Jensen. 1992. Production and identification of primary trisomics in diploid crested wheatgrass (Agropyron cristatum) p. 100. In Agronomy abstracts. ASA, Madison, WI.

Isaac, E. 1970. Geography of domestication. Prentice Hall, Englewood Cliffs, NJ.

Jauhar, P.P. 1993. Aneuploids. p. 113-119. Cytogenetics of the Festuca-Lolium complex: Relevance to breeding. Springer-Verlag, New York, Berlin, Heidelberg.

Jenkin, T.J. 1943. Aberystwyth strains of grasses and clovers. Agriculture (London) 50:343-349.

Jessen, D.L., and I.T. Carlson. 1985. Response to selection for seed and forage traits in smooth bromegrass. Crop Sci. 25:502-505.

Jessen, D.L., I.T. Carlson, and C.F. Hodges. 1983. Growth-chamber and field reaction of three smooth bromegrass strains to Pyrenophora bromi (Died.) Drechsl. Crop Sci. 23:709-711.

Johnson, D.A., and K.H. Asay. 1993. Viewpoint: Selection for improved drought response in coolseason grasses. J. Range Manage. 46:194-202. 
Jones, M.L., and M.O. Humphreys. 1993. Progress in breeding interspecific hybrid ryegrasses. Grass Forage Sci. 48:18-25.

Jones, T.A., I.T. Carlson, and D.R. Buxton. 1989. Legume compatability of reed canarygrass clones related to agronomic and other morhpological traits. Crop Sci. 29:1-7.

Jowett, D. 1959. Adaptation of a lead-tolerant population of Agrostis tenuis to low soil fertility. Nature (London) 184:43.

Jung, G.A., and J.A. Shaffer. 1990. Fall management studies with Matura prairie grass. p. 147. In Agronomy abstracts. ASA, Madison, WI.

Jung, G.A., A.J.P. Van Wijk, W.F. Hunt, and C.E. Watson. 1996. Ryegrasses. p. 605-641. In L.E. Moser et al. (ed.) Cool-season forage grasses. Agron. Monogr. 34. ASA, CSSA, and SSSA, Madison, WI.

Kalton, R.R., R.E. Barker, and R.E. Welty. 1996. Seed production. p. 383-411. In L.E. Moser (ed.) Cool-season forage grasses. Agron. Monogr. 34. ASA, CSSA, and SSSA, Madison, WI.

Kamstra, L.D., J.G. Ross, and D.C. Ronning. 1973. In vivo and in vitro relationships in evaluating digestibility of selected smooth bromegrass synthetics. Crop Sci. 13:575-576.

Karn, J.F., J.M. Krupinsky, and J.D. Berdahl. 1989. Nutritive quality of foliar disease resistant and susceptible strains of intermediate wheatgrass. Crop Sci. 29:436-439.

Kasperbauer, M.J. 1990a. Haploids: Derivation and evaluation. p. 79-96. In M.J. Kasperbauer (ed.) Biotechnology in tall fescue improvement. CRC Press, Inc., Boca Raton, FL.

Kasperbauer, M.J. 1990b. Doubled haploids: Derivation and evaluation. p. 97-108. In M.J. Kasperbauer (ed.) Biotechnology in tall fescue improvement. CRC Press, Inc., Boca Raton, FL.

Kasperbauer, M.J., R.C. Buckner, and L.P. Bush. 1979. Tissue culture of annual ryegrass $\times$ tall fescue $F_{1}$ hybrids: Callus establishment and plant regeneration. Crop Sci. 19:457-460.

Kindler, S.D., T.L. Springer, and K.B. Jensen. 1991. Differential damage to range grass seedlings by Russian wheat aphid (Homoptera: Aphididae). J. Econ. Entomol. 84:333-336.

Klebesadel, L.J., and D. Helm. 1986. Food reserve storage, low-temperature injury, winter survival, and forage yields of timothy in subarctic Alaska as related to latitude-of-origin. Crop Sci. 26:325-334.

Knowles, R.P. 1977. Recurrent mass selection for improved seed yields in intermediate wheatgras. Crop Sci. 17:51-54.

Knowles, R.P., D.A. Cooke, and E. Buglass. 1970. Breeding for seed yield and seed quality in smooth bromegrass, Bromus inermis Leyss. Crop Sci. 10:539-542.

Krueger, C.R., and J.M. Scholl. 1970. Performance of bromegrass, orchardgrass and reed canarygrass grown at five nitrogen levels and with alfalfa. Univ. Wisconsin Agric. Exp. Stn. Res. Rep. 69. Univ. Wisconsin, Madison.

Krupinsky, J.M., and J.D. Berdahl. 1982. Selection for resistance in intermediate wheatgrass to leaf spot caused by Helminthosporium sativum. Can. J. Plant Pathol. 4:65-68.

Kumar, P.S., and P.D. Walton. 1992. Plant regeneration and chromosome instability in tissue culture Elymus canadensis $\times$ E. trachycaulus $\mathrm{F}_{1}$ hybrid. Genome 35:88-91.

Lancashire, J.A., D. Wilson, R.W. Bailey, M.J. Ulyatt, and P. Singh. 1977. Improved summer performance of a 'Low Cellulose' selection from 'Grasslands Ruanui' hybrid perennial ryegrass. N.Z. J. Agric. Res. 20:63-67.

Larkin, P.J., and W.R. Scowcroft. 1981. Somaclonal variation-a novel source of variability from cell cultures for plant improvement. Theor. Appl. Genet. 60:197-214.

Lawrence, T. 1977. Effects of selection for speed of germination on establishment, vigor, and yield in Altai wild ryegrass. Can. J. Plant Sci. 57:1085-1090.

Lawrence, T. 1979. Swift, Russian wild ryegrass. Can. J. Plant Sci. 59:515-518.

Lawrence, T., and C.D. Ratzlaff. 1988. Effects of selection for foliage color on the seed and forage yield of Altai wild ryegrass. Can. J. Plant Sci. 68:1003-1007.

Lazenby, A., and H.H. Rogers. 1964. Selection criteria for grass breeding. II. Effect, on Lolium perenne, of differences in population density, variety and available moisture. J. Agric. Sci. 62:285-298.

Levin, D.A. 1973. The role of trichomes in plant defense. Quart. Rev. Biol. 48:3-15.

Levin, D.A. 1976. The chemical defenses of plants to pathogens and herbivores. Ann. Rev. Ecol. Syst. 7:121-159.

Levy, E.B. 1929. Strain investigation relative to grasses and cloyers. N.Z. J. Agric. 39:1-8.

Levy, E.B. 1932. New Zealand pasture seeds. What the dominion has to offer. N.Z. J. Agric. 44:253262. 
Levy, E.B., and S.H. Saxby. 1933. Strain investigation of grasses and clover. N.Z. J. Agric. 47:366375.

Lewis, E.J. 1983. Cytogenetic aspects of interspecific hybridization in relation to breeding in the ryegrass/fescue complex. p. 218-235. In Welsh Plant Breeding Stn. Ann. Rep. for 1982. Welsh Plant Bred. Stn., Aberystywth, Wales.

Lewis, E.J., M.W. Humphreys, and M.P. Caton. 1980. Chromosome location of two isozyme loci in Lolium perenne using primary trisomics. Theor. Appl. Genet. 57:237-239.

Lodge, G.M. 1993. The domestication of the native grasses Danthonia richardsonii Cashmore and Danthonia linkii Kunth for agricultural use. I. Selecting for inflorescence seed yield. Aust. J. Agric. Res. 44:59-77.

Lodge, G.M., and A.J. Schipp. 1993. The domestication of the native grasses Danthonia richardsonii Cashmore and Danthona linkii Kunth for agricultural use. II. Agronomic and morphologic variation. Aust. J. Agric. Res. 44:79-88.

Lonnquist, J.H., W.A. Compton, J.L. Geadelmann, F.A. Loeffel, B. Shank, and A.F. Troyer. 1979. Convergent-divergent selection for area improvement in maize. Crop Sci. 19:602-604.

Love, R.M. 1969. Registration of Palestine orchardgrass. Crop Sci. 9:523.

Macnair, M.R. 1991. Why the evolution of resistance to anthropogenic toxins normally involves major gene changes: the limits to natural selection. Genetica 84:213-219.

Macnair, M.R., Q.J. Cumbes, and A.A. Meharg. 1992. The genetics of arsenate tolerance in Yorkshire fog, Holcus lanatus L. Heredity 69:325-335.

Madsen, S., A. Olesen, and S.B. Andersen. 1993. Self-fertile doubled haploid plants of perennial ryegrass (Lolium perenne L.). Plant Breed. 110:323-327.

Mansat, P., and M. Betin. 1979. Sélection du Ray-grass d'Italie pour la résistance à la Rouille couronnée en conditions artificielles. Ann. Amélior. Plant. 29:337-347.

Marburger, J.E., and R.R.-C. Wang. 1988. Anther culture of some perennial triticeae. Plant Cell Rep. 7:313-317.

Marshall, S.W., and A.E. Slinkard. 1972. Mass selection versus maternal-line selection in Russian wildrye. Crop Sci. 12:537-538.

Marten, G.C. 1973. Alkaloids in reed canarygrass. p. 15-31. In A.G. Matches (ed.) Anti-quality components of forages. CSSA Spec. Publ. 3. CSSA, Madison, WI.

Marten, G.C. 1989. Breeding forage grasses to maximize animal performance. p. 71-104. In D.A. Sleper et al. (ed.) Contributions from breeding forage and turf grasses. CSSA Spec. Publ. 15. ASA and CSSA, Madison, WI.

Marum, P., A.W. Hovin, G.C. Marten, and J.S. Shenk. 1979. Genetic variability for cell wall constituents and associated quality traits in reed canarygrass. Crop Sci. 19:355-360.

Matches, A.G. 1992. Plant response to grazing: A review. J. Prod. Agric. 5:1-7.

Matzk, F. 1981. Successful crosses between Festuca arundinacea and Dactylis glomerata L. Theor. Appl. Genet. 60:119-122.

McLean, S.D., and C.E. Watson, Jr. 1992. Divergent selection for anthesis date in annual ryegrass. Crop Sci. 32:847-851.

McNaughton, S.J. 1979. Grassland-herbivore dynamics. p. 46-81. In A.R.E. Sinclair and M. NortonGriffiths (ed.) Serengeti. Dynamics of an ecoysstem. Univ. Chicago Press, Chicago, IL.

McNaughton, S.J., M.B. Coughenour, and L.L. Wallace. 1982. Interactive processes in grassland ecosystems. p. 167-193. In J.R. Estes et al. (ed.) Grasses and grasslands. Sysematics and ecology. Univ. Oklahoma Press, Norman.

McWilliam, J.R. 1963. Selection of seed retention in Phalaris tuberosa L. Aust. J. Agric. Res. 14:755-764.

Meijer, E.G.M., and B.S. Ahloowalia. 1981. Trisomics of ryegrass and their tramsmission. Theor. Appl. Genet. 60:135-140.

Miller, T.L., and I.T. Carlson. 1982. Breeding for rust resistance in orchardgrass by phenotypic and phenotypic-genotypic selection. Crop Sci. 22:1218-1221.

Moodie, A.W.S. 1934. Strains in perennial ryegrass and cocksfoot, with particular reference to types found in pastures in New South Wales. Herb. Rev.2:85-87.

Moore, K.J., K.P. Vogel, T.J. Klopfenstein, and B.E. Anderson. 1990. Forage quality of intermediate wheatgrass under grazing. p. 190. In Agronomy abstracts. ASA, Madison, WI.

Munro, J.M.M., and R.J.K. Walters. 1986. The feeding value of grass. p. 65-78. In J. Frame (ed.) Grazing. Proc. Occ. Symp. no. 19, Malvern, Worcestershire, England. 5-7 Nov. 1985. Br. Grassl. Soc., Reading, England.

National Research Council. 1991. Managing global genetic resources. The U.S. National Plant Germplasm System. Natl. Acad. Press. Washington, DC. 
Nelson, C.J., K.M. Hasson, D.A. Sleper, and J.R. Forwood. 1989. Compatibility of birdsfoot trefoil with tall fescue selected for high and low leaf area expansion rate. p. 467-468. In R.R. Jarrige et al. (ed.) Proc. 16th Int. Grassl. Congr., Nice, France. 4-11 October. French Grassl. Soc.

Nguyen, H.T., D.A. Sleper, and A.G. Matches. 1982. Inheritance of forage quality and its relationship to leaf tensile strength in tall fescue. Crop Sci. 22:67-72.

Nicholls, M.K., and T. McNeilly. 1985. The performance of Agrostis capillaris L. genotypes, differing in copper tolerance, in ryegrass swards on normal soil. New Phytol. 101:207217.

Nielson, D.C., K.H. Asay, and T.A. Jones. 1993. Bluegrass billbug feeding response to perennial triticeae grasses. J. Range Manage. 46:237-240.

Nielsen, G., H. Østergaard, and H. Johansen. 1985. Cultivar identification by means of isoenzymes. II. Genetic variation at four enzyme loci in diploid ryegrass.Plant Breed. 94:74-86.

Niu, Y., G.J. Scoles, and K.N. Kao. 1991. Anther culture of seven perennial Triticeae. p. 199. In Agronomy abstracts. ASA, Madison, WI.

Noitsakis, B., and P. Jacquard. 1992. Competitoin between cyanogenic and acyanogenic morphs of Trifolium repens. Theor. Appl. Genet. 83:433-450.

Norton, B.E., and P.S. Johnson. 1981. Pattern of defoliation by cattle grazing crested wheatgrass pastures. p. 462-464. In J.A. Smith and V.W. Hays (ed.) Proc. 14th Int. Grassl. Congr., Lexington, KY. 15-24 June. Westview Press, Boulder, CO.

Novy, E.M., M.D. Casler, and R.R. Hill, Jr. 1995. Selection for persistence of tetraploid ryegrasses and festulolium in mixture with perennial legumes. Crop Sci. 35:1046-1051.

Oberheim, R.L., C.C. Berg, R.T. Sherwood, and K.E. Zeiders. 1987. Yield and quality of forage from orchardgrass selected for resistance to purple leaf spot. Crop Sci. 27:673-676.

Olesen, A., S.B. Andersen, and I.K. Due. 1988. Anther culture response in perennial ryegrass (Lolium perenne L.). Plant Breed. 101:60-65.

Owen, D.F., and R.G. Wiegert. 1981. Mutualism between grasses and grazers: An evolutionary hypothesis. Oikos 36:376-378.

Park, C.H., and P.D. Walton. 1989a. Embryo-callus-regenerated hybrids and their colchicine-induced amphiploids between Elymus canadensis and Secale cereale. Theor. Appl. Genet. 78:721-727.

Park, C.H., and P.D. Walton. 1989b. Embryogenesis and plant regeneration from tissue culture of Canada wildrye, Elymus canadensis L. Plant Cell Rep. 8:289-291.

Pedersen, J.F., R.L. Haaland, C.S. Hoveland, C.D. Berry, P. Schmidt, and R.R. Harris. 1983. Registration of AU Triumph tall fescue. Crop Sci. 23:182.

Perez-Vicente, R., L. Petris, M. Osusky, I. Potrykus, and G. Spangenberg. 1992. Molecular and cytogenetic characterization of repetitive DNA sequences from Lolium and Festuca: Applications in the analysis of Festulolium hybrids. Theor. Appl. Genet. 84:145-154.

Petersen, H.L. 1976. Competition in Lolium perenne L. as measured by yield and persistency. p. 129-140. In B. Dennis (ed.) Breeding methods and variety testing in forage plants. Proc. EUCARPIA Fodder Crops Sec, Lyngby Landbrugsskole, Denmark. 7-9 Sept. R. Vet. Agric. Univ., Højbakkegård, Denmark.

Pfitzermeyer, C.D.C. 1962. Arrhenatherum eliatus (L.) J. et C. Presl. (A. avenaceum Beauv.). J. Ecol. 50:235-245.

Poehlman, J.M. 1983. Breeding field crops. AVI Publ. Co., Inc., Westport, CN.

Ratner, J. 1990. Identifying quantitative traits in plants. Bio/Technology 8:401-403.

Ray, I., and M.K. Tokach. 1992. Cytology of 2 n pollen formation in diploid crested wheatgrass, Agropyron cristatum (L.) Gaernt. Crop Sci. 32:1361-1365.

Read, J.J., K.H. Asay, and D.A. Johnson. 1993. Divergent selection for carbon isotope discrimination in crested wheatgrass. Can. J. Plant Sci. 73:1027-1035.

Reed, J.N., and B.V. Conger. 1985. Meiotic analyses of tall fescue plants regenerated from callus cultures. Environ. Exp. Bot. 25:277-284.

Reed, K.F.M., P.J. Cunningham, J.T. Barrie, and J.F. Chin. 1987. Productivity and persistence of cultivars and Algerian introductions of perennial ryegrass (Lolium perenne L.) in Victoria. Aust. J. Exp. Agric. 27:267-274.

Reich, J.M., and M.D. Casler. 1985. Effect of maturity and alfalfa competition on expected selection response for smooth bromegrass forage quality traits. Crop Sci. 25:635-640.

Rhodes, I. 1969. The relationship between productivity and some components of canopy structure in ryegrass (Lolium spp.). I. Leaf length. J. Agric. Sci. 7:315-319.

Rhodes, I. 1971. The relationship between productivity and some components of canopy structure in ryegrass (Lolium spp.). II. Yield, canopy structure and light interception. J. Agric. Sci. 77:283-292. 
Rhodes, I. 1975. The relationship between productivity and some components of canopy structure in ryegrass (Lolium spp.). IV. Canopy characters and their relationship with sward yields in some intra population selections. J. Agric. Sci. 84:345-351.

Rind, M.J., and I.T. Carlson. 1988. Bidirectional greenhouse selection for dry-matter digestibility in orchardgrass. p. 94. In Agronomy abstracts. ASA, Madison, WI.

Robson, M.J. 1982a. The growth and carbon economy of selection lines of Lolium perenne cv. S23 with differing rates of dark respiration. 1. Grown as simulated swards during a regrowth period. Ann. Bot. 49:321-329.

Robson, M.J. 1982b. The growth and carbon economy of selection lines of Lolium perenne cv. S23 with differing rates of dark respiration. 2. Grown as young plants from seed. Ann. Bot. 49:331-339.

Ross, J.G., S.S. Bullis, and K.C. Lin. 1970. Inheritance of in vitro digestibility in smooth bromegrass. Crop Sci. 10:672-673.

Rotili, P., L. Zannone, and G. Gnocchi. 1976. Effects of association and density in clones of tall fescue (Festuca arundinacea L.). p. 141-151. In B. Dennis (ed.) Breeding methods and variety testing in forage plants. Proc. EUCARPIA Fodder Crops Sec., Lyngby Landbrugsskole, Denmark. 7-9 September. R. Vet. Agric. Univ., Højbakkegård, Denmark.

Rumball, W. 1974. 'Grasslands Matua' prairie grass (Bromus catharticus Vahl.). N.Z. J. Exp. Agric. 2:1-5.

Rybczynski, J.J., Z. Zwierzykowski, and A. Slusarkiewicz-Jarzina. 1983. Plant regeneration with doubled chromosome number in tissue culture of $\mathrm{F}_{1}$ Lolium-Festuca hybrids. Genet. Pol. $24: 1-7$

Sachs, A.P.W., and B.E. Coulman. 1983. Variability in reed canarygrass collections from Eastern Canada. Crop Sci. 23:1041-1044.

Saiga, S. 1983. Selection effect for digestibility of summer regrowth in orchardgrass. p. 143-146. In J.A. Smith and V.W. Hays (ed.) Proc. 14th Int. Grassl. Congr., Lexington, KY. 15-24 June 1981. Westview Press, Boulder, CO.

Sanders, P.M., and D.J. Barker. 1988. Pasture plant identification using enzyme electrophoresis. Proc. N.Z. Grassl. Assoc. 49:77-80.

Schmidt, D.R., and G.H. Tenpas. 1965. Seasonal response of grasses fertilized with nitrogen compared to a legume-grass mixture. Agron. J. 57:428-431.

Scholz, H. 1975. Grassland evolution in Europe. Taxon 24:81-90.

Shoop, M., E.H. Mcllvain, and P.W. Voigt. 1976. Morpa weeping lovegrass produces more beef. J. Range Manage. 29:101-103.

Short, K.E., and I.T. Carlson. 1989. Bidirectional selection for birdsfoot trefoil-compatibility traits in orchardgrass. Crop Sci. 29:1131-1136.

Silcock, R.G., and D. Wilson. 1982. Effect of reduced soil moisture availability on leaf morphology and in vitro dry matter digestibility of Festuca arundinacea genotypes with contrasting leaf tensile strength. New Phytol. 91:277-285.

Simons, A.B., and G.C. Marten. 1971. Relationship of indole alkaloids to palatability of Phalaris arundinacea L. Agron. J. 63:915-919.

Singh, R.J. 1993. Plant cytogenetics. CRC Press, Boca Raton, FL.

Skipp, R.A., and D.W.R. White. 1988. Somaclonal variation in resistance of perennial ryegrass to crown rust. Proc. N.Z. Grassl. Assoc. 49:93-96.

Sleper, D.A. 1987. Forage grasses. p. 161-208. In W.R. Fehr (ed.) Principles of cultivar development. Vol. 2. Macmillian Publ. Co., New York.

Sleper, D.A., P.N. Drolsom, and N.A. Jorgensen. 1973. Breeding for improved dry matter digestibility in smooth bromegrass (Bromus inermis Leyss). Crop Sci. 13:556-558.

Sleper, D.A., and C.J. Nelson. 1989. Productivity of selected high and low leaf area expansion Festuca arundinacea strains. p. 379-380. In R. Jarrige et al. (ed.) Proc. 16th Int. Grassl. Congr., Nice, France. 4-11 October. French Grassl. Soc.,

Sleper, D.A., and C.P. West. 1996. Tall fescue. p. 471-502. In L.E. Moser et al. (ed.) Cool-season forage grasses. Agron. Monogr. 34. ASA, CSSA, and SSSA, Madison, WI.

Smith, D., A.V.A. Jacques, and J.A. Balasko. 1973. Persistence of several temperate grasses grown with alfalfa and harvested two, three, and four times annually at two stubble heights. Crop Sci. 13:553-556.

Smith, D.C. 1948. The breeder's ways and means. p. 331-341. In A. Stefferud (ed.) Grass, the yearbook of agriculture, 1948. U.S. Govt. Print. Office, Washington, DC.

Smith, D.C. 1956. Nature of forage crop varieties in relation to methods of improvement. p. 404414. In G.J. Neale (ed.) Proc. 7th Int. Grassl. Congr., Palmerston North, NZ. 6-15 November. Wright and Carman, Ltd., Wellington, NZ. 
Smith, J.D., and R.P. Knowles. 1967. Mass selection for resistance to Selenophoma bromigena in northern and southern types of Bromus inermis. Can. J. Plant Sci. 47:679-681.

Smith, M.A., C.E. Watson, Jr., S.D. Linscombe, and L.E. Trevathan. 1986. Selection for resistance to Cochliobolus sativus in tall fescue (Festuca arundinacea Schreb.). Theor. Appl. Genet. 72:807-810.

Smith, R.L., M.E. Schweder, M.K.U. Chowdhury, J.E. Seib, and S.C. Schank. 1993. Development and appliction of RFLP and RAPD DNA markers in genetic improvement of Pennisetum for biomass production. Biomass Bioener. 5:51-62.

Snaydon, R.W. 1970. Rapid population differentiation in a mosaic environment. I. The response of Anthoxanthum odoratum populations to soils. Evolution 24:257-269.

Snaydon, R.W. 1973. Ecological factors, genetic variation and speciation in plants. p. 1-29. In V.H. Heywood (ed.) Taxonomy and ecology. Acad. Press, New York.

Snaydon, R.W. 1978. Genetic changes in pasture populations. p. 253-269. In J.R. Wilson (ed.) Plant relations in pastures. CSIRO, East Melbourne, Australia.

Snaydon, R.W., and M.W. Davies. 1972. Rapid population differentiation in a mosaic environment. II. Morphological variation in Anthoxanthum odoratum. Evolution 26:390-405.

Stapledon, R.G. 1924. The economic significance of the concepts, nationality, variety and strain, as applied more particularly to herbage plants. J. Natl. Inst. Agric. Bot. 2:1-10.

Stapledon, R.G. 1928. Cocksfoot grass (Dactylis glomerata L.): Ecotypes in relation to the biotic factor. J. Ecol. 16:71-104.

Stebbins, G.L. 1981. Coevolution of grasses and herbivores. Ann. Missouri Bot. Gard. 68:75-86.

Sullivan, J.T., E.S. Titlar, and T.V. Hershberger. 1962. Chemical composition of nonheading orchardgrass plants. J. Anim. Sci. 21:138.

Surprenant, J., D.K. Barnes, R.H. Busch, and G.C. Marten. 1988. Bidirectional selection for neutral detergent fiber and yield in reed canarygrass. Can. J. Plant Sci. 68:705-712.

Surprenant, J., R. Michaud, and G. Allard. 1990. Effect of one cycle of divergent phenotypic selection for crude protein, digestibility and digestible yield in timothy. Can. J. Plant Sci. 70:757-765.

Symeonidis, L., T. McNeilly, and A.D. Bradshaw. 1985. Interpopulation variation in tolerance to cadmium, copper, lead, nickel, and zinc in nine populations of Agrostis capillaris L. New Phytol. 101:317-324.

Takamizo, T., G. Spangenberg, K. Suginobu, and I. Potrykus. 1991. Intergeneria somatic hybridization in Gramineae: somatic hybrid plants between tall fescue (Festuca arundinacea Schreb.) and Italian ryegreass (Lolium multiflorum Lam.). Mol. Gen. Genet. 231:1-6.

Takamizo, T., K.-I. Suginobu, and R. Ohsugi. 1990. Plant regeneration from suspension culture derived protoplasts of tall fescue (Festuca arundinacea Schreb.) of a single genotype. Plant Sci. 72:125-131.

Tan, Y., G. Tan, and P.D. Walton. 1978. Genetic variability in acid detergent fiber, crude protein, and their association with some morphological characters in smooth bromegrass. Crop Sci. 18:119-121.

Tanksley, S.D., N.D. Young, A.H. Paterson, and M.W. Boniarbale. 1989. RFLP mapping in plant breeding: New tools for an old science. Bio/Technology 7:257-264.

Taylor, H.J., and J.N.B. Bell. 1988. Studies on the tolerance to $\mathrm{SO}_{2}$ of grass populations in polluted areas. V. Investigations into the development to tolerance to $\mathrm{SO}_{2}$ and $\mathrm{NO}_{2}$ in combination and $\mathrm{NO}_{2}$ alone. New Phytol. 110:327-338.

Tcacenco, F.A., C.F. Eagles, and B.F. Tyler. 1989. Evaluation of winter hardiness in Romanian introductions of Lolium perenne. J. Agric. Sci. 112:249-255.

Terrell, E.E. 1968. A taxonomic revision of the genus Lolium. USDA Tech. Bull. 1392. U.S. Gov. Print. Office, Washington, DC.

Thomas, H. 1993. Fluorescence in situ hybridization. p. 13-14. In AFRC Inst. Grassland Environmental Res. Rep., 1992. Welsh Plant Breed. Stn., Aberystwyth, Wales.

Thomas, H., and C. Evans. 1989. Effects of divergent selection for osmotic adjustment of water relations and growth of plants of Lolium perenne. Ann. Bot. 64:581-587.

Thomas, H., and C. Evans. 1991. Growth and water relations of simulated swards of Lolium perenne L. selection lines with contrasting leaf osmotic potentials. Grass Forage Sci. 46:391-397.

Thomas, H., and M.O. Humphreys. 1991. Progress and potential of interspecific hybrids of Lolium and Festuca. J. Agric. Sci. (Cambridge) 117:1-8.

Tilley, J.M.A., and R.A. Terry. 1963. A two-stage technique for in vitro digestion of forage crops. J. Br. Grassl. Soc. 18:104-111.

Trupp, C.R., and I.T. Carlson. 1971. Improvement of seedling vigor of smooth bromegrass (Bromus inermis Leyss.) by recurrent selection for high seed weight. Crop Sci. 11:225-228. 
Tsurumi, Y., T. Yoshiyama, K. Nakashima, and H. Yamaguchi. 1985. Characteristic differences of survival plants under grazing from the original varieties in orchardgrass (Dactylis glomerata L.). p. 286-287. In Proc. 15th Int. Grassl. Conf., Kyoto, Japan. 24-31 August. Jpn. Soc. Grassl. Sci., Nishi-nasuno, Tochigi-ken, Japan.

Turesson, G. 1922. The genotypical response of the plant species to the habitat. Hereditas 3:211350 .

Tyler, B.F. 1987. Description and distribution of natural variation in forage grasses. p. 13-22. In Natural variation and breeding for adaptation. Proc. EUCARPIA Fodder Crops Sect., Lusignan, France. 22-24 Sept. 1987. INRA Stn. d'Amélioration des plants Fourragèros, France.

Tyler, B.F., K.H. Chorlton, and I.D. Thomas. 1987. Collection and field-sampling techniques for forages. p. 3-10. In B.F. Tyler (ed.) Collection, characterization and utilization of genetic resources of temperate forage grass and clover. IBPGR Train. Courses: Lect. Ser. 1. Int. Bd. Plant Gen. Resour., Rome.

Ugherughe, P.O., P.N. Drolsom, and J.R. Davis. 1980. Influence of planting pattern on estimated digestibility of smooth bromegrass. Crop Sci. 20:695-699.

van der Valk, P., M.A.C.M. Zaal, and J. Creemers-Molenaar. 1988. Regeneration of albino plantlets from suspension culture derived protoplasts of Poa pratensis L. (Kentucky bluegrass). Euphytica (Supplement):169-176.

Van Bogaert, G. 1975. A comparison between colchicine induced tetraploid and diploid cultivars of Lolium species. p. 61-78. In B. Nüesch (ed.) Ploidy in fodder plants. EUCARPIA Fodder Crops Sect., Zürich, Switzerland. 23-25 April. Swiss Fed. Res. Stn. Agron., Zurich.

Van Bogaert, G. 1977. Scope for improving the yield of grasses and legumes by breeding and selection. p. 29-35. In Proc. Int. Meet. Anim. Prod. Temperate Grassl., Dublin, Ireland. 25-28 July. Irish Grassl. Anim. Prod. Assoc., Agric. Inst., Belclare, Tuam, Ireland.

Van Dijk, G.E. 1955. The influence of sward-age and management on the type of timothy and cocksfoot. Euphytica 4:83-93.

Van Dijk, G.E. 1959. Breeding for quality in cocksfoot (Dactylis glomerata L.). Euphytica 8:5868.

Van Dijk, G.E. 1979. Breeding Lolium perenne L. for yield and persistence under heavy nitrogen and infrequent cutting. p. 131-135. In S. Ceccarelli (ed.) Breeding for stress conditions. Proc. EUCARPIA Fodder Crops Sect., Perugia, Italy. 4-6 September. Ist. d'Allévamento Veg., Perugia, Italy.

Van Dijk, G.E. 1983. Spaced plants in swards as a testing procedure in grass breeding. p. 130-132. In J.A. Smith and V.W. Hays (ed.) Proc. 14th Int. Grassl. Congr., Lexington, KY. 15-24 June 1981. Westview Press, Boulder, CO.

van Santen, E., and M.D. Casler. 1990. Methods of visually rating maturity in tetraploid Dactylis. Plant Breed. 105:26-32.

van Santen, E., P.M. Hugessen, and M.D. Casler. 1991. Identification and frequency of tetraploid progeny from $2 x-4 x$ and $4 x-2 x$ crosses in Dactylis. Genome 34:273-278.

Van Soest, P.J. 1982. Nutritional ecology of the ruminant. O \& B Books, Inc., Corvallis.

Venables, A.V., and D.A. Wilkins. 1978. Salt tolerance in pasture grasses. New Phytol. 80:613622.

Vogel, K.P., J.H. Gorz, and F.A. Haskins. 1989. Breeding grasses for the future. p. 105-122. In D.A. Sleper et al. (ed.) Contributions from breeding forage and turf grasses. CSSA Spec. Pub1. 15. CSSA, Madison, WI.

Vogel, K.P., K.J. Moore, and L.E. Moser. 1996. Bromegrasses. p. 535-567. In L.E. Moser et al. (ed.) Cool-season forage grasses. Agron. Monogr. 34. ASA, CSSA, and SSSA, Madison, WI.

Vogel, K.P., and J.F. Pedersen. 1993. Breeding systems for cross-pollinated perennial grasses. Plant Breed. Rev. 11:251-274.

Walley, K.A., M.S.I. Khan, and A.D. Bradshaw. 1974. The potential for evolution of heavy metal tolerance in plants. I. Copper and zinc tolerance in Agrostis tenuis. Heredity 32:309-319.

Wang, A.Y., M.P. Valles, P. Montavon, I. Potrykus and G. Spangerberg. 1993. Fertile plant regeneration from protoplasts of meadow fescue (Festuca pratensis Huds.). Plant Cell Rep. 12:95100.

Wang, R.R-C. 1987. Synthetic and natural hybrids of Psathyrostachys huashanica. Genome 29:811816.

Wang, R.R-C., J.E. Marburger, and C.-J. Hu. 1991. Tissue-culture-facilitated production of aneupolyhaploid Thinopyrum ponticum and amphidiploid Hordeum violaceum $\times H$. bogdanii and their uses in phylogenetic studies. Theor. Appl. Genet. 81:151-156. 
Wang, Z., T. Takamizo, V.A. Iglesias, M. Osusky, J. Nagel, I. Potrykus, and G. Spangenberg. 1992. Transgenic plants of tall fescue (Festuca arundinacea Schreb.) obtained by direct gene transfer to protoplasts. Bio/technology 10:691-696.

Watkin, B.R., and R.J. Clements. 1978. The effects of grazing animals on pastures. p. 273-289. In J.R. Wilson (ed.) Plant relations in pastures. CSIRO, East Melbourne, Australia.

Webber, H.J. 1912. The production of new and improved varieties of timothy. Cornell Univ. Agric. Exp. Stn. Bull. 313:339-391.

Wedderburn, M.E., W.J Pengelly, and L.A. Greaves. 1993. Comparison of improved "low-fertility" grass species and ryegrass with wild populations for performance under varying levels of nitrogen and moisture in a simulated hill soil profile. N.Z. J. Agric. Res. 36:117-121.

Wedderburn, M.E., M.A. Tucker, W.J. Pengelly, and S.F. Ledgard. 1990. Responses of a New Zealand North Island hill perennial ryegrass collection to nitrogen, moisture stress, and grass grub (Costelytra zelandica) infestation. N.Z. J. Agric. Res. 33:405-411.

Wedin, W.F., and D.R. Huff. 1996. Bluegrasses. p. 665-690. In L.E. Moser et al. (ed.) Coolseason forage grasses. Agron. Monogr. 34. ASA, CSSA, and SSSA, Madison, WI.

Weedon, N.F., and A.C. Emmo. 1985. Isozyme characterization of Kentucky bluegrass cultivars. Can. J. Plant Sci. 65:985-994.

Weiss, M.G., and S.K. Mukerji. 1950. Effect of planting method and nitrogen fertilization on relative performance of orchardgrass strains. Agron. J. 42:555-559.

Westerholt, S.R., and T.P. Riordan. 1992. The application of flow cytometry in the determination of ploidy levels of Kentucky bluegrass and buffalograss. p. 178. In Agronomy abstracts. ASA, Madison, WI.

Wilkins, P.W. 1975. Inmplications of host-pathogen variation for resistance breeding in the grass crop. Ann. Appl. Biol. 81:257-261.

Wilkins, P.W. 1978. Specialization of crown rust on highly and moderately resistant plants of perennial ryegrass. Ann. Appl. Biol. 88:179-184.

Wilkins, P.W. 1991. Breeding perennial ryegrass for agriculture. Euphytica 52:201-214.

Williams, J.G., M.K. Hanafey, J.A. Rafalski, and S.V. Tingley. 1993. Genetic analysis using random amplified polymorphic DNA markers. In R. Wu (ed.) Recombinant DNA (Part I). Method. Enzymol. 218:704-740.

Williams, J.T. 1984. The international germplasm program of the International Board of Plant Genetic Resources (IBPGR). p. 21-25. In W.L. Brown et al. (ed.) Conservation of crop germplasm-an international perspective. CSSA Spec. Publ. 8. CSSA, Madison, WI.

Wilsie, C.P. 1949. Evaluation of grass-legume associations, with emphasis on yields of bromegrass varieties. Agron. J. 41:412-420.

Wilson, D. 1975a. Leaf growth, stomatal diffusion resistances and photosynthesis during droughting of Lolium perenne populations selected for contrasting stomatal length and frequency. Ann. Appl. Biol. 79:67-82.

Wilson, D. 1975b. Stomatal diffusion resistances and leaf growth during droughting of Lolium perenne plants selected for contrasting epidermal ridging. Ann. Appl. Biol. 79:83-94.

Wilson, D. 1976. Physiological and morphological selection criteria in grasses. p. 9-18. In B. Dennis (ed.) Breeding methods and variety testing in forage plants. EUCARPIA Fodder Crops Sec., Roskilde, Denmark. 7-9 September. Royal Vet. Agric. Univ., Højbakkegård, Taastrup, Denmark.

Wilson, D. 1981. The role of physiology in breeding herbage cultivars adapted to their environment. p. 95-108. In C.E. Wright (ed.) Plant physiology and herbage production. Proc. Occ. Symp. no. 13, Nottingham, England. 1-9 April. Br. Grassl. Soc., Reading, England.

Wilson, D. 1982. Response to selection for dark respiration rate of mature leaves in Lolium perenne and is effects on growth of young plants and simulated swards. Ann. Bot. 49:303-312.

Wilson, D. 1984. Development of better selection criteria. p. 117-129. In W Lange et al. (ed.) Efficiency in plant breeding. Proc. 10th EUCARPIA Congr., Wageningen, 19-24 June 1983. Pudoc, Wageningen, the Netherlands.

Wilson, D., and J.P. Cooper. 1970. Effect of selection for mesophyll cell size on growth and assimilation in Lolium perenne L. New Phytol. 69:233-245.

Wilson, D., and J.G. Jones. 1981. Leaf tensile strength in cocksfoot. p. 136-137. In Welsh Plant Breed. Stn. Ann. Rep. for 1980. Aberystwyth, Wales.

Wilson, D., and J.G. Jones. 1982. Effect of selection for dark respiration rate of mature leaves on crop yields of Lolium perenne cv. S23. Ann. Bot. 49:313-320.

Wilson, G.B., and J.N.B. Bell. 1985. Studies on the tolerance to $\mathrm{SO}_{2}$ of grass populations in polluted areas. III. Investigations on the rate of development of tolerance. New Phytol. 100:6377. 
Wilson, G.B., and J.N.B. Bell. 1986. Studies on the tolerance to $\mathrm{SO}_{2}$ of grass populations in polluted areas. IV. The spatial relatinship between tolerance and a point source of pollution. New Phytol. 102:563-574.

Wilson, G.B., and J.N.B. Bell. 1990. Studies on the tolerance to $\mathrm{SO}_{2}$ of grass populations in polluted areas. VI. The genetic nature of tolerance in Lolium perenne L. New Phytol. 116:313317.

Wit, F. 1974. Cytoplasmic male sterility in ryegrasses (Lolium spp.) detected after intergeneric hybridization. Euphytica 23:31-38.

Witte, H. 1919. Breeding timothy at Svalöf. J. Hered. 10:290-299.

Wu, L. 1981. The potential for evolution of salinity tolerance in Agrostis stolonifera L. and Agrostis tenuis Sibth. New Phytol. 89:471-486.

Wu, L., A.D. Bradshaw, and D.A. Thurman. 1975. The potential for evolution of heavy metal tolerance in plants. III. The rapid evolution of copper tolerance in Agrostis stolonifera. Heredity $34: 165-187$.

Xu, W.W., D.A. Sleper, and S. Chao. 1992. Detection of RFLPs in perennial ryegrass, using heterologous probes from tall fescue. Crop Sci. 32:1366-1370.

Xu, W.W., D.A. Sleper, and D.A. Hoisington. 1991. A survey of restriction fragment length polymorphisms in tall fescue and its relatives. Genome 34:686-692.

Xu, W.W., D.A. Sleper, and G.F. Krause. 1994. Genetic diversity of tall fescue germplasm based on RFLPs. Crop Sci. 34:246-252.

York, P.A., and R. Cook. 1989. Variation in forage grasses as hosts of the root-knot nematode Meloidogyne naasi (Franklin) and selection for resistance in ryegrass. Euphytica 43:135141.

Zannone, L., P. Rotili, R. Paoletti, and C. Scotti. 1986. Experimental studies of grass-legume associations. Agronomie 6:931-940.

Zeiders, K.E., C.C. Berg, and R.T. Sherwood. 1984. Effect of recurrent phenotypic selection on resistance to purple leaf spot in orchardgrass. Crop Sci. 24:182-185.

Zohary, D. 1984. Modes of evolution under domestication. p. 579-586. In W.F. Grant (ed.) Plant biosystematics. Acad. Press, New York. 